

\title{
Tank Monitor and Control System (TMACS) Revision 11.0 Acceptance Test Review
}

\author{
M. J. Holm \\ Lockheed Martin Hanford Corporation, Richland, WA 99352 \\ U.S. Department of Energy Contract DE-AC06-96RL13200
}

EDT: 627426

Org Code: 74B00

B\&R Code: EW3120071
UC: 605

Charge Code: 102608/EB00

Total Pages: 110

Key Words: Acceptance. Test Review, ATR, TMACS, Tank Monitor and Control System.

Abstract: This document contains the test results of the Revision 11.0 Acceptance Test Procedure for the Tank Monitor and Control System (TMACS) .

TRADEMARK DISCLAIMER. Reference herein to any specific comercial product, process, or service by trade name, trademark, manufacturer, or otherwise, does not necessarily constitute or imply its endorsement, recommendation, or favoring by the United States Government or any agency thereof or its contractors or subcontractors.

Printed in the United States of America. To obtain copies of this document, contact: Docunent Control Services, P.O. Box 950, Mailstop H6-08, Richland WA 99352, Phone (509) 372-2420; Fax (509) 376-4989.

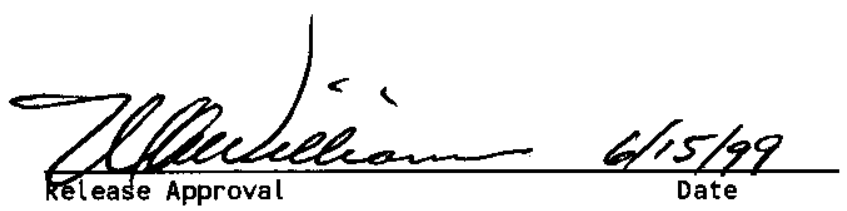

Approved for Public Release 


\begin{tabular}{|l|l|}
\hline $\begin{array}{l}\text { 2. To: (Receiving Organization) } \\
\text { Distribution }\end{array}$ & $\begin{array}{l}\text { 3. From: (Originating Organization) } \\
\text { Process Control }\end{array}$ \\
\hline $\begin{array}{l}\text { 5. Proj./Prog./Dept./Div.: } \\
\text { Tank Monjtor and Control }\end{array}$ & $\begin{array}{l}\text { 6. Design Authority/ Design Agent/cog. } \\
\text { Engr: }\end{array}$ \\
System (TMACS) & $\mathrm{J}$. Holm \\
\hline $\begin{array}{l}\text { 8. Originator Remarks: } \\
\text { For approval and release of a new supporting document. This } \\
\text { document has been generated to document the testing of the } \\
\text { TMACS. }\end{array}$
\end{tabular}

11. Receiver Remarks:

11A. Design Baseline Docunent?

[] Yes

$[X]$ No
4. Related EDT NO.:

$\mathrm{N} / \mathrm{A}$

7. Purchase Order No.:

$N / A$

9. Equip./Component No.:

$\mathrm{N} / \mathrm{A}$

10. System/Bldg./Facility: 2750/TMACS

12. Major Assm. Dwg. No.:

\section{$\mathrm{N} / \mathrm{A}$}

13. Permit/Permit Application No.: $\mathrm{N} / \mathrm{A}$

14. Required Response Date: $\mathrm{N} / \mathrm{A}$

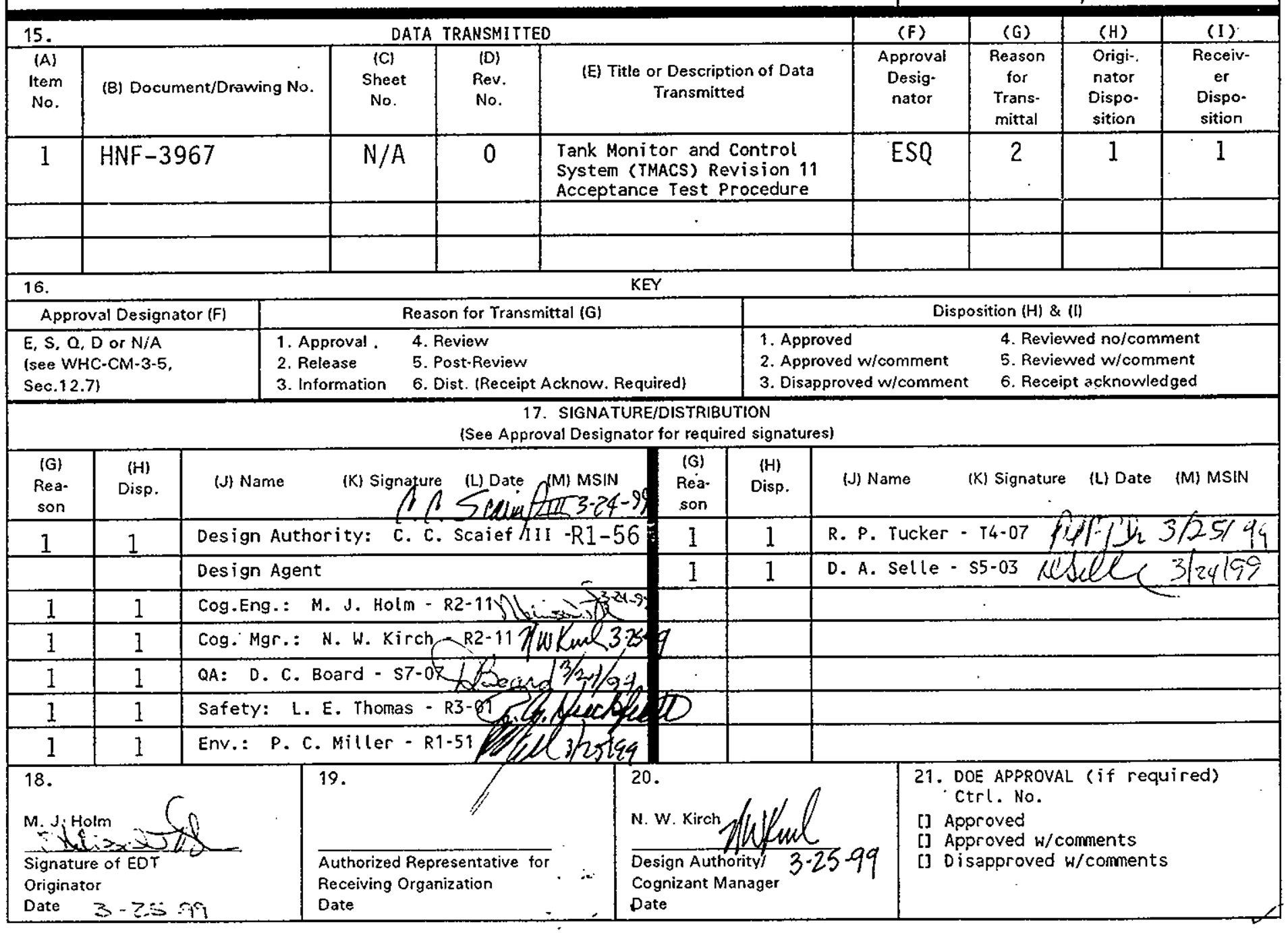

$$
\begin{gathered}
\text { HNF-4368 } \\
\text { Rewo }
\end{gathered}
$$




\section{Tank Monitor and Control System (TMACS) Revision 11 Acceptance Test Procedure}

Ronald R. Wandling

Lockheed Martin Services, Inc., Richland, WA 99352

U.S. Department of Energy Contract DE-AC06-96RL13200

EDT: 625998

Org Code: 74B00

B\&R Code: EW3120071
UC: 605

Charge Code: 102608/EB00

Total Pages: 70

Key Words: TMACS, Tank Monitor and Control, Rev. 11.0.

Abstract: This document is used to validate Revision 11.0 of the Tank Monitor and Control System (TMACS) and verify its functions as intended by design.

TRADEMARK DISCLAIMER. Reference herein to any specific commercial product, process, or service by trade name, trademark, manufacturer, or otherwise, does not necessarily constitute or imply its endorsement, recommendation, or favoring by the United States Government or any agency thereof or its contractors or subcontractors.

Printed in the United States of America. To obtain copies of this document, contact: Document Control Services, P.O. Box 950, Mailstop H6-08, Richland WA 99352, Phone (509) 372-2420;

Fax (509) 376-4989.

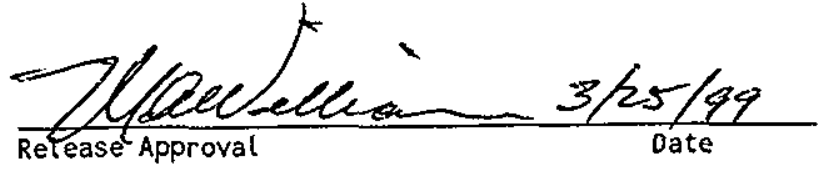

Approved for Public Release HNF-4368

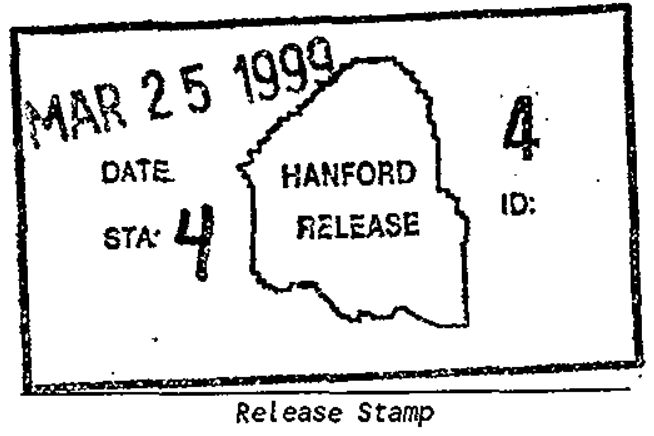


HNF-4368, Rev. 0

\title{
TANK MONITOR AND CONTROL SYSTEM (TMACS) REVISION 11 ACCEPTANCE TEST PROCEDURE
}

\author{
Prepared By \\ Ronald R. Wandling \\ Lockheed Martin Services Inc.
}

For

Lockheed Martin Hanford

For

US Department of Energy

Richland Operations Office

Richland, Washington 
1. INTRODUCTION................................................................................................................ 1

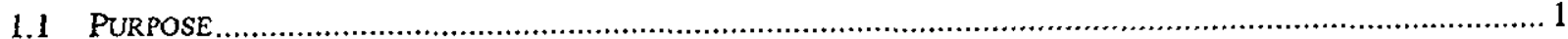

1.2 SCOPE.

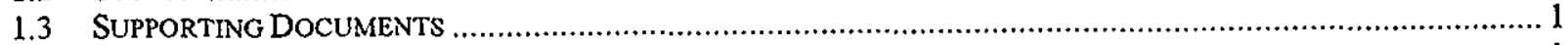

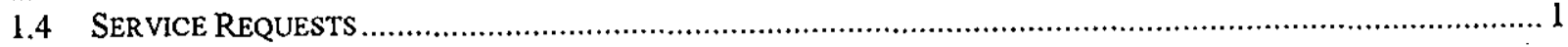

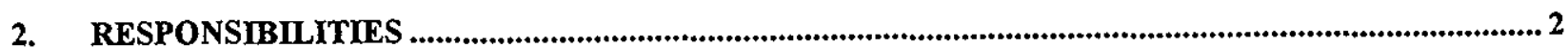

2.1 TEST DIRECTOR

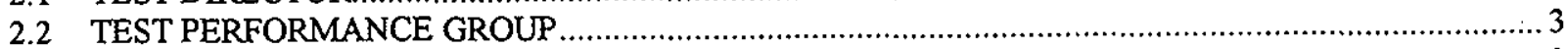

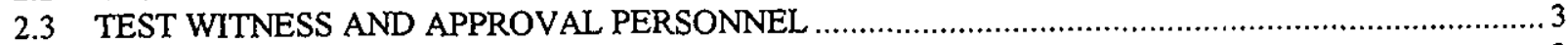

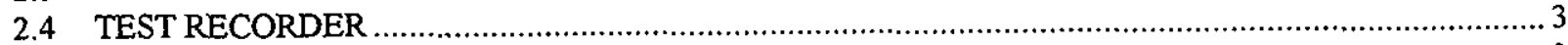

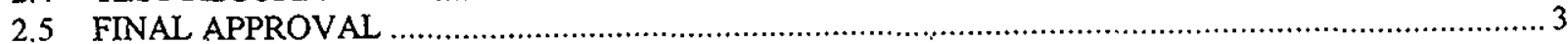

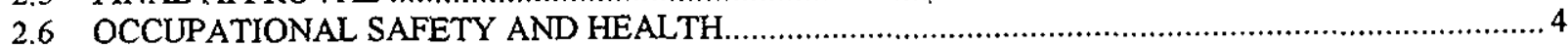

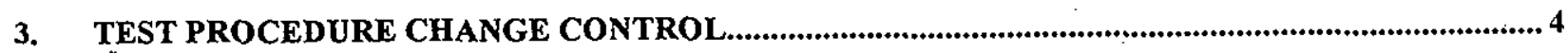

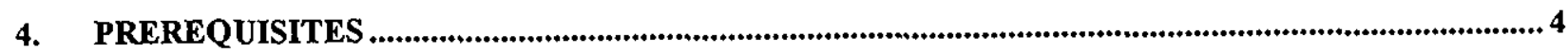

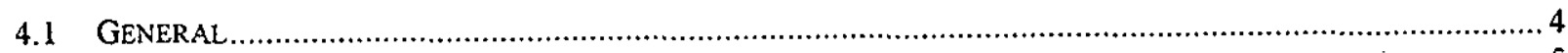

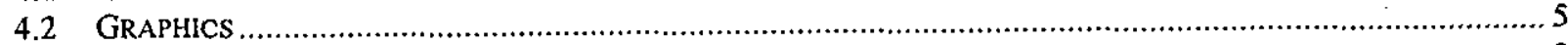

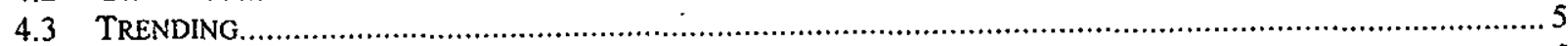

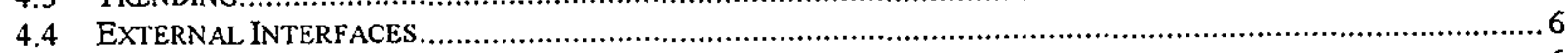

4.5 POINT PROCESSING

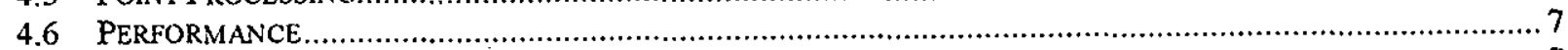

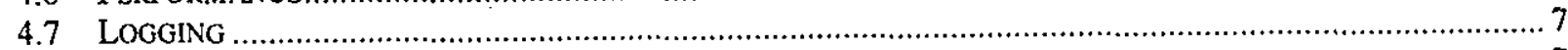

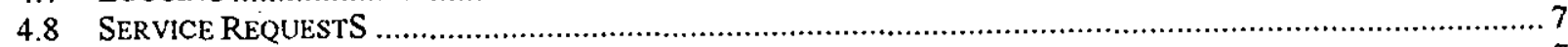

4.8.1 SR 772 - Correct TMACS Data History Recovery ........................................................................ 7

4.8 .2 SR 7 78-Enra ${ }^{8}$ Driver polls with incorrect message .............................................................. 8

4.8.3 SR 784-Modify TMACS' continuous point processing to assure at least one reading a day.............. 8

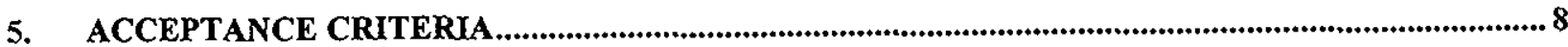

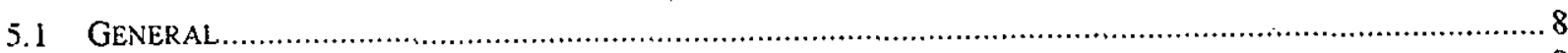

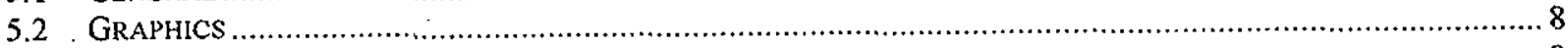

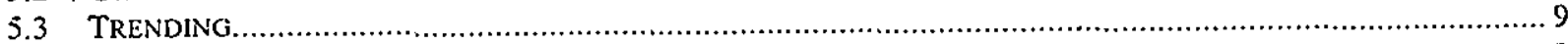

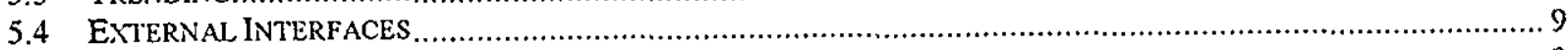

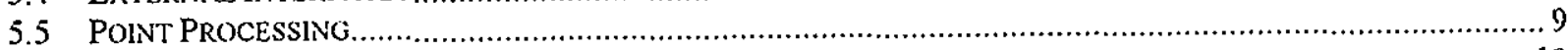

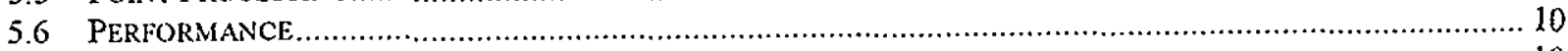

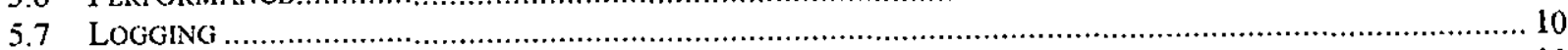

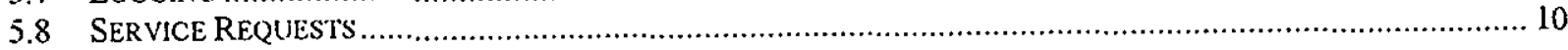

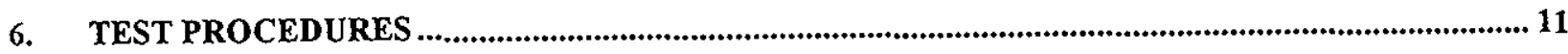

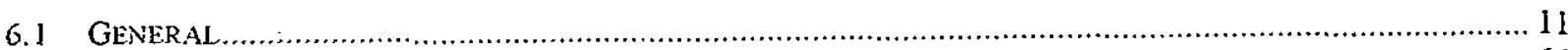

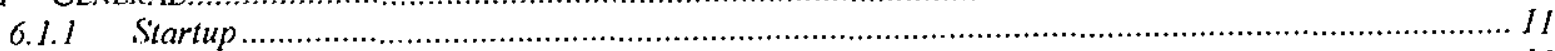

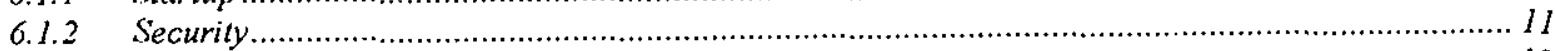

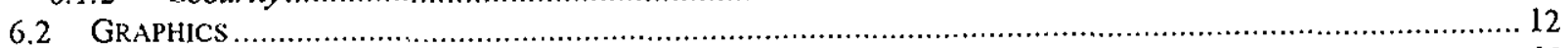

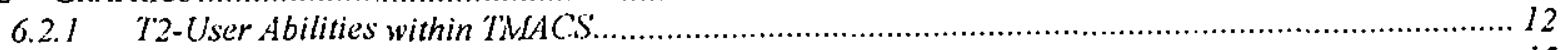

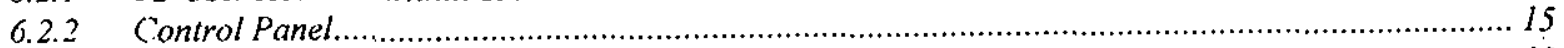

6.2 .3 Hanford Tank Farm Facility ..................................................................................... 18

6.2.t Operation Of The Print Button.................................................................................... 19

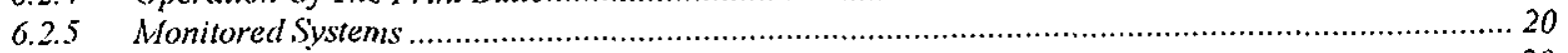

6.3 TRENDING

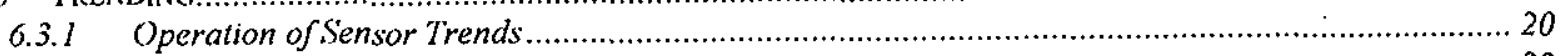

6.3.2 Operation of User Selectable trends.................................................................................. 22 


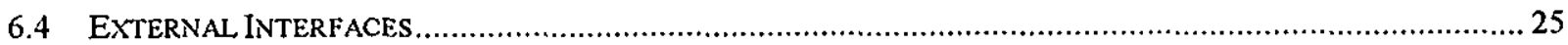

6.4.1 Acromag ${ }^{\text {TM }}$

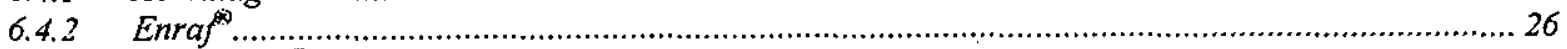

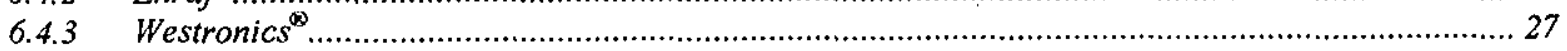

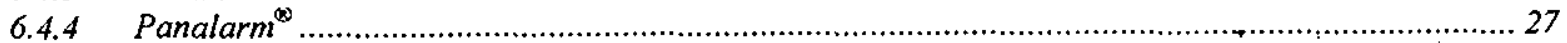

6.4.5 SACS

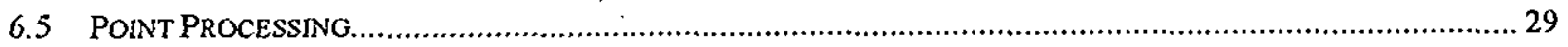

6.5.1 Continuous Sensor (Non Rate of Change) Automated Functional Test ......................................... 29

6.5.2 Continuous Sensor (Rate of Change) Automated Functional Test ................................................ 30

6.5.3 Discrete Sensor Automated Functional Test .............................................................................. 30

6.5.4 Operation of MOST RECENT ALARM and CURRENT ALARMS ............................................. 30

6.5.5 Operation of Sensor Delta Band and Alarm Deadband ............................................................. 32

6.5.6 Operation of Enable/Disable Procedures................................................................................ 33

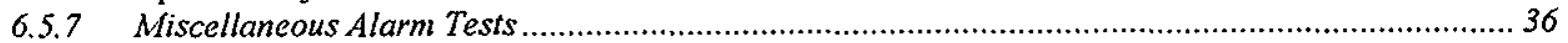

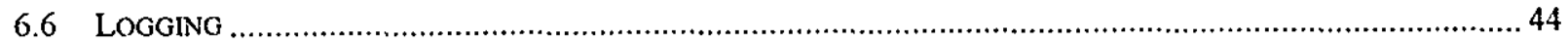

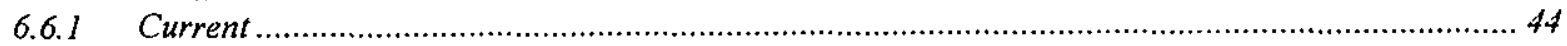

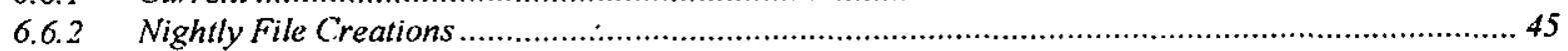

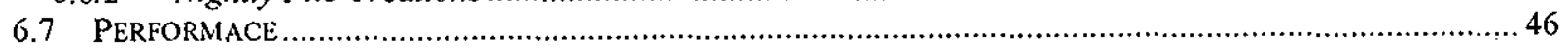

6.7.1 CPU Use Vs Number of Continuous Points/Sec Performance Test ................................................ 46

6.7.2 CPU Use Vs Number of Discrete Points/Sec Performance Test ............................................... 47

6.7.3 CPU Use Vs Pt-Processing Function for Continuous Points Performance Test............................... 47

6.7.4 CPU Use Vs Point-Processing Function for Discrete Points Performance Test............................... 48

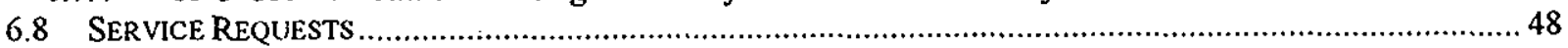

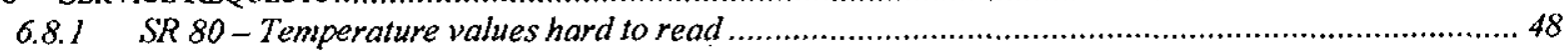

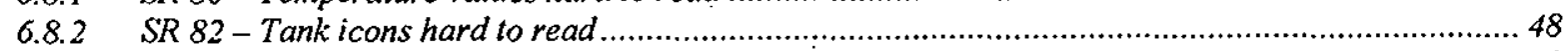

6.8.3 SR 99-C.-106 Sensor Configuration Changes ......................................................................... 48

$0.8 .4 \quad$ SR 104-Make TMACS colors readable …….............................................................................49

6.8.5 SR 114-Convert TX Farm Trend Graphs To Trend Charts ........................................................ 49

6.8.6 SR 129 - Upgrade All Selectable Trend Graphs To Trend Charts..............................................49

0.8.7 SR 458 - Change the time that the nightly flat fles are created ..................................................49

6.8.8 SR 471-Sensor Trends display sensor identifier as tag list identifier.......................................... 50

6.8 .9 SR 660 - Convert TMACS from UNLXTM to WindowsNT TM.....................................................50 50

6.8.10 SR 704-Redirection of I/O Drivers from Production to Development..........................................50

6.8 .11 SR 748-Enraf ${ }^{*}$ Drivers polls with incorrect message ............................................................... 51

0.8 .12 SR 749 - TMACS Alarm Printer gsi interface configuration ..................................................... 52

6.8 .13 SR 757 - Enraf does not handle "FFFFFF" error message correctly ........................................52

6.8 .14 SR $762-\left(U-108\right.$ Enraf $f^{*}$ conversion formula ..........................................................................52

6.8 .15 SR 763 - Fix Reference Junction Formulas......................................................................... 52

6.8.16 SR 769 - Sensor Detail Button on Individual Sensor Trends .................................................... 52

6.8.17 SR 770-Make TMAC.S Surface Level function definitions uniform ............................................ 53

6.8 .18 SR 771-Add Discrete Update Button to TMACS displays containing Discrete 1/O points ............... 53

6.8.19 SR 772 - Correct TMAACSS Data History Recovery ....................................................................... 54

6.8.20 SR 775 - Fix Abort Problem When Discrete Values Are Outside Instrument Limits......................... 54

6.8.21 SR 782 - File Read Status On TMACSS Startup ........................................................................ 54

6.8 .22 SR 783 - Correct Scaling problem with Individual Sensor Trends ........................................... 54

6.8.23 SR 784-Modify TMLACS continuous point processing to assure at least one reading a day ............ 55

$6.8 .24 S R 791$ - Label Trend Charts that include 2 risers ..................................................................... 55

6.8 .25 SR 823 - Modify User Trend charts to support persistence .........................................................5 56

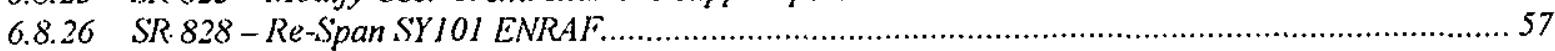

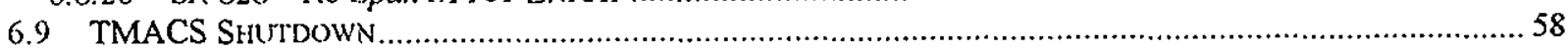

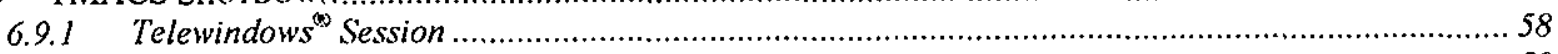

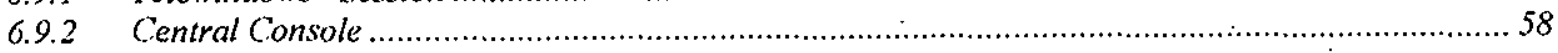

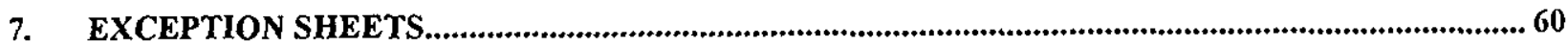

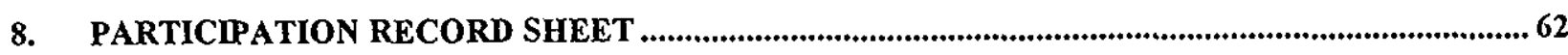




\section{HNF-4368, Rev. 0}

9. ACCEPTANCE RECORD SHEET..

This Document consists of pages 1 through 88 , plus pages 16.1, 17.1, 18.1, 23.1, 28.1, $28.2,28.3,29.1,29.2,30.1,30.2,44.1,46.1,46.2$, and 47.1 . 


\section{INTRODUCTION}

\subsection{PURPOSE}

The purpose of this document is to describe tests performed to validate Revision 11 of the TMACS Monitor and Control System (TMACS) and verify that the software functions as intended by design.

\subsection{SCOPE}

This document is intended to test the software portion of TMACS. The tests will be performed on the development system. The software to be tested is the TMACS knowledge bases (KB) and the $\mathrm{I} / \mathrm{O}$ driver/services. The development system will not be talking to field equipment; instead, the field equipment is simulated using emulators or multiplexers in the lab.

\subsection{SUPPORTING DOCUMENTS}

- "Double-Shell Underground Waste Storage Tanks - Riser Survey," SD-RE-TI-093, Rev. 1, December 2, 1986.

- "Riser Configuration Document for Single-Shell Waste Tanks", SD-RE-TI-053, Rev. 8, August 22, 1991.

- "TMACS I/O Termination Point Listing", WHC-SD-WM-TI-594, Current Revision.

- "TMACS Data File Formats, Release 11.0," Lockheed Martin Services, Inc. External Letter, RGG-SDI-99-001.

\subsection{SERVICE REQUESTS}

The following are the change request incorporated into the TMACS software for this release.

\begin{tabular}{|l|l|}
\hline \multicolumn{1}{|c|}{$\mathrm{SR} \#$} & \multicolumn{1}{|c|}{ Abbreviated Description } \\
\hline 80 & Temperature values hard to read \\
\hline 82 & Tank icons hard to read \\
\hline 99 & C106 Sensor Configuration Changes \\
\hline 104 & Make TMACS colors readable \\
\hline 114 & Convert TX Farm Trend Graphs To Trend Charts \\
\hline 458 & Upgrade All Selectable Trend Graphs To Trend Charts \\
\hline
\end{tabular}


HNF-4368, Rev. 0

\begin{tabular}{|c|c|}
\hline SR & 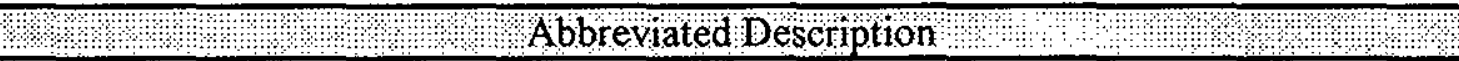 \\
\hline 471 & Sensor Trends display sensor identifier as tag list identifier \\
\hline 660 & Convert TMACS from UNIX ${ }^{1}$ to WindowsNT ${ }^{2}$ \\
\hline 704 & Redirection of V/O Drivers from Production to Development \\
\hline 748 & Enraf $^{3}$ Driver polls with incorrect message \\
\hline 749 & TMACS Alarm Printer gsi ${ }^{4}$ interface configuration \\
\hline 757 & Enraf ${ }^{(2)}$ does not handle "FFFFFF" error message properly \\
\hline 762 & U-108 Enraf ${ }^{8}$ conversion formula \\
\hline 763 & Fix Reference Junction Formulas \\
\hline 769 & Sensor Detail Button on Individual Sensor Trends \\
\hline 770 & Make TMACS Surface Level function definitions uniform \\
\hline 771 & Add Discrete Update Button to TMACS displays containing Discrete $1 / O$ points \\
\hline 772 & Correct TMACS Data History Recovery \\
\hline 775 & Fix Abort Problem When Discrete Values Are Outside Instrument Limits \\
\hline 782 & File Read Status On TMACS Start Up \\
\hline 783 & Correct Scaling problem with Individual Sensor Trends \\
\hline 784 & Modify TMACS continuous point processing to assure at least one reading a day \\
\hline$\overline{791}$ & Label Trend Charts that include 2 risers \\
\hline 823 & Modify User Trend Charts to support persistence. \\
\hline 828 & Re-Span SY101 ENRAF \\
\hline
\end{tabular}

\section{RESPONSIBILITIES}

Each organization participating in the conduct of this ATP will designate personnel to assume the responsibilities and duties as defined herein for their respective roles. Prior to the performance of this ATP these designees shall sign the ATP Participation Sheet.

\subsection{TEST DIRECTOR}

- Provides concurrence that the ATP may commence.

- Act as liaison between the test performance group and the test witnesses.

- Shall perform the test as described in this document.

- Record exceptions and test steps that are not performed on the ATP Exception Record sheets. Add additional Exception Record sheets as needed.

\footnotetext{
${ }^{1}$ UNIX is a trademark of X/Open Company, Ltd.

${ }^{2}$ WindowsNT is a trademark of the Microsoft Corporation.

${ }^{3}$ Enraf is a registered trademark of Enraf, B.V.

${ }^{4} \mathrm{GSI}$ is a trademark of the Gensym Corporation.
} 
HNF-4368, Rev. 0

- Shall obtain final approval signatures and distribute copies of the ATP.

- Stop any test that, in the judgment of the Test Director, may cause damage to the system until the test procedure has been revised.

\subsection{TEST PERFORMANCE GROUP}

- Shall provide qualified personnel, tools and equipment required to perform test.

\subsection{TEST WITNESS AND APPROVAL PERSONNEL}

- Shall observe the testing and data recording to verify that their group's requirements are met.

- If any representative of the witness and approval personnel objects to the results obtained during the acceptance test, he shall notify the Test Director. Any such notice, if not resolved directly to the representative's satisfaction, shall be recorded as an exception.

\subsection{TEST RECORDER}

- Get signatures on the Recorder's copy of the Acceptance Test Procedure Participation sheet prior to testing.

- Observe tests and record test data (if any).

- Initial every test step on the Recorder's copy as it is completed, next to the step number or table, when provided.

- Record exceptions and test steps, which are not performed on the Exception Sheet.

- Notify the Test Director of an exception at time the exception is made.

- Transfer Recorder's copy of the completed ATP with the final test results and signatures to the Test Director for Final Approval signatures and disposition.

\subsection{FINAL APPROVAL}

- Approval personnel shall indicate, by their signature on the ATP Acceptance Record Sheet that the ATP result's are accepted. Any questions or objections shall be referred to the Test Director for resolution.

If the approval personnel find an exception to the test that is of sufficiently small magnitude, a test approval may be given. In this case, a list of such exceptions shall be entered in the 
exception page as "Test Approved with Exceptions," signed and dated. This signature shall indicate that the exceptions are of such a nature that a rerun of the ATP is not necessary to demonstrate that the exceptions have been adequately resolved.

\subsection{OCCUPATIONAL SAFETY AND HEALTH}

- Individuals shall perform their assigned tasks in a safe manner to protect themselves and others from undue hazards and to prevent damage to property and environment.

\section{TEST PROCEDURE CHANGE CONTROL}

Acceptance testing shall be conducted in accordance with the steps and requirements specified in this procedure. In the event minor changes are required to successfully complete the Acceptance Test Procedure the change shall be noted as an exception and testing continued, only if the change will not effect the test acceptance criteria. The exception shall be incorporated into this document in accordance with HNF-PRO-440, "Engineering Document Change Control, Requirements."

\section{PREREQUISITES}

This section describes the prerequisites required to perform this ATP. The section contains general prerequisites that apply to this test procedure as well as specific prerequisites for individual test procedures.

\subsection{GENERAL}

The following are the prerequisites for running any of the test sections described in this procedure.

1. The Test Director should bring up $G 2^{5}$ with the TMACS_Main.KB and log in using the mode "t2-user" prior to running the formal test.

2. The Test Director should bring up a $\mathrm{G} 2^{\infty}$ telewindows 6 session and log in using the mode "t2-user" prior to running the formal test.

3. The Test Director should verify that following bridges/services are started as services on WindowsNTTM.

${ }^{5} \mathrm{G} 2$ is a registered trademark of the Gensym Corporation.

${ }^{6}$ Telewindows is a registered trademark of the Gensym Corporation. 


\section{HNF-4368, Rev. 0}

\begin{tabular}{|c|c|c|}
\hline Common Name & Executable & Service Name \\
\hline Acromag $^{7} \mathrm{I} / \mathrm{O}$ driver & Acromag_driver.exe & $\begin{array}{l}\text { AcromagDriver } 22200 \\
\text { AcromagDriver } 22201 \\
\text { AcromagDriver } 22202 \\
\text { AcromagDriver } 22203 \\
\text { AcromagDriver } 22204 \\
\text { AcromagDriver } 22205\end{array}$ \\
\hline Alarm Printer driver & Tmacs_printer_driver.exe & TMACSPrtDriver 22300 \\
\hline Enraf ${ }^{n} \mathrm{I} / \mathrm{O}$ driver & Enraf_driver.exe & EnrafDriver 22206 \\
\hline Panalarm ${ }^{8} \mathrm{I} / \mathrm{O}$ driver & Panalm_driver.exe & PanalmDriver 22207 \\
\hline Westronic ${ }^{9} \mathrm{I} / \mathrm{O}$ driver & Westronic.driver & WestronicDriver 22212 \\
\hline $\mathrm{G} 2{ }^{2}$ ODBC Bridge & & $\mathrm{G} 2^{6}$ ODBC Bridge \\
\hline
\end{tabular}

4. The Test Director shall have available the latest version of the following reference

- materials:

- “TMACS I/O Termination Point Listing", (WHC-SD-WM-TI-594, current revision), document written by Instrument \& Control (I\&C). The electronic version is available at IVAP014ITMACS.

- "Riser Configuration Document for Single-Shell Waste Tanks", (SD-RE-TI-053, Rev. 8).

- Double-Shell Underground Waste Storage Tanks - Riser Survey", (SD-RE-TI-093, Rev. 1).

5. The serial multiplexers or emulators for the Acromag ${ }^{\mathrm{TM}}$, Enraf $^{\mathrm{N}}$, Panalarm, ${ }^{\infty}$ and

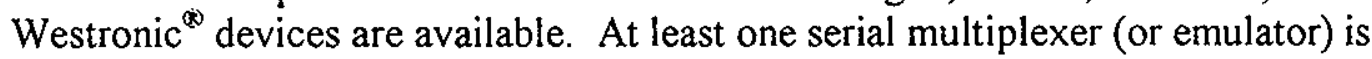
attached to the test computer and that the appropriate driver can function through the appropriate serial port.

\subsection{GRAPHICS}

No additional prerequisites are needed.

\subsection{TRENDING}

To give a proper display of trending it is strongly advised that 1 or more days of history files be copied from production to the system to be tested (give enough time for the files to be processed) and run into the development TMACS.

\footnotetext{
${ }^{7}$ Acromag is a trademark of Acromag Incorporated, Wixom, Michigan.

${ }^{8}$ Panalarm is a registered trademark of Ametek, Inc.

${ }^{9}$ Westronics is a registered trademark of Westronics, Inc.
} 


\subsection{EXTERNAL INTERFACES}

No additional prerequisites are needed.

\subsection{POINT PROCESSING}

1. This test requires the system to be in a state in which no other alarm activity is generated externally. The Test Director may need to disable the collection of sensor readings from the lab equipment and clear alarm messages generated by the system start up.

2. The individual Test Cases are built using tank "Test-201", which contains one discrete and one continuous sensor. The current values for these sensors are entered programmatically; the tests assume that the following parameters have been set for sensor Continuous-200001. Verify that the sensor has the parameters in Table 1.

Table 1. Parameters for Sensor Continuous-200001

\begin{tabular}{|l|l|}
\hline 1ै 1 Parameter & Value \\
\hline High Instrument Limit & 22 \\
\hline High Alarm Limit & 15 \\
\hline Low Alarm Limit & 10 \\
\hline Low Instrument Limit & 4 \\
\hline Delta Band & 0.0 \\
\hline Alarm Deadband & 0.9 \\
\hline Rate of Change & 1.2 \\
\hline ROC Limit & 2.2 \\
\hline
\end{tabular}

3. Verify that the discrete sensor, Discrete-200001, has the values for the parameters listed in Table 2.

Table 2. Parameters for Sensor Discrete-200001

\begin{tabular}{|l|l|l|}
\hline State $0=$ Normal & Color = Green & Annotation = OPEN \\
\hline State $1=$ Alarm & Color $=$ Yellow & Annotation = CLOSING \\
\hline State $2=$ Alarm & Color $=$ Red & Annotation = CLOSED \\
\hline State $3=$ Normal & Color = Green & Annotation = OPENING \\
\hline High Instrument Limit $>3$ & Low Instrument Limit $<0$ \\
\hline
\end{tabular}

4. To set up the tests in this section the Test Director must:

- Load the testing knowledge base (KB)

- Bring up the Point Processing Functional Tests workspace

- Enter the test document revision number (i.e. 11.0). 
5. The functional tests will be run individually in the test cases. The tester must be logged in to $\mathrm{G} 2$ in "administrator" mode.

\subsection{PERFORMANCE}

1. This purpose of this test section is to bench mark the production software using the development computer. The tests will be performed on the computer with the minimum TMACS processes running. The development computer will be running the following software during the test:

- WindowsNT'M and related system programs that will be running in production

- $\mathrm{G} 2^{*}$ with the production TMACS knowledge bases. There should be no data recovery operations in place during the test!!!

- All driver services that would be running in production. None of these services should be receiving data from the field, lab, or emulators.

2. To set up the tests in this section the Test Director must:

- Acknowledge all the alarms from the startup process

- Load the testing knowledge base (KB)

- Hide all the workspaces until only the $\mathrm{G} 2^{\infty}$ background bricks appear

- Bring up the Point Processing Performance Tests workspace

- Enter the test document revision number (i.e. 11.0).

\subsection{LOGGING}

The Test Director may want to start and have the TMACS system running overnight to create the automated data files for this test.

\subsection{SERVICE REQUESTS}

\subsubsection{SR 772 - Correct TMACS Data History Recovery}

The Test Director shall generate, on the production computer, a hard copy of one or two trend charts that have an easily identifiable trend.

The Test Director shall have loaded history data (more than one day) from the production system prior to running this test. Note: It lakes approximately 1-2 hours to read in one day's worth of data. 


\subsubsection{SR 748 - Enraf ${ }^{(8)}$ Driver polls with incorrect message}

The hardware required is:

- The TMACS development computer(s)

- A serial multiplexer (or emulator) attached to the test computer through the serial port monitored by the Enraf ${ }^{\text {d) }}$ driver.

- A serial analyzer used to monitor the communication between TMACS and the emulator.

To set this test up the Test Director must perform the following steps:

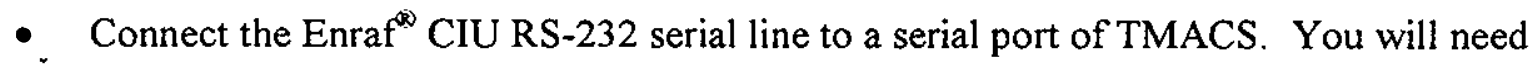
to use a NULL modem to reverse the Receive/Transmit lines since both the workstation . and the CIU are DTE devices.

- Connect a Serial Analyzer between the serial port and the serial line to the CIU

- All the Enraf ${ }^{(2)}$ CIU Station Objects in the $G 2^{\infty}$ knowledge base are using the same GSI ${ }^{\mathrm{TM}}$ interface

- Make sure $\mathrm{G} 2^{\infty}$ is running and not paused.

\subsubsection{SR 784 - Modify TMACS continuous point processing to assure at least one reading a day}

The Test Director may want to start and have the TMACS system running overnight to create the automated data files for this test.

\section{ACCEPTANCE CRITERIA}

\subsection{GENERAL}

The system shall provide multiple security levels that are password protected.

\subsection{GRAPHICS}

The acceptance criteria for graphics is:

- Provide real-time display of numeric values of sensors

- Communicate with a minimum of 2 graphics CRTs

- Provide "PRINT" facility for graphic window displays. 


\subsection{TRENDING}

The acceptance criteria trending is:

- Provide real-time trend graphs, with the following selected time intervals: 1 hour, 7 days.

\subsection{EXTERNAL INTERFACES}

The system shall be capable of providing sensor information to the Surveillance Analysis Computer System (SACS) for sensors configured in both SACS and TMACS.

The acceptance criteria sensor conversion is:

- The system shall convert the data read by the field equipment in a user readable format.

\subsection{POINT PROCESSING}

The acceptance criteria trending is:

- Provide real-time alarming on high and low level for any analog point

- Provide alarm deadband filtering for analog points

- Display the following alarm colors: red for highest priority, requiring immediate action; yellow for an abnormal condition requiring attention but not an immediate hazard; white for status indication; green for normal condition

- Provide alarm summary display with date, time, tag, description, alarm status with color-coding (green for normal). Remove message from display upon acknowledgement and reset/return to normal

- Display tanks and sensors with unacknowledged alarms as blinking

- Provide operator alarm acknowledgement. Acknowledgement action shall cease blinking of alarmed item

- Provide logging of alarms, return to normal, and alarm acknowledgements, to printer and to disk

- Provide alarming when error codes are returned from data acquisition system. 


\subsection{PERFORMANCE}

The acceptance criteria trending is:

- The TMACS G2 $2^{\infty}$ program shall process input from 50 points per second while using less than $80 \%$ of the CPU time.

\subsection{LOGGING}

The acceptance criteria trending is:

- The system shall have the capability to log any sensor value

- A sensor logging shall include the time stamp and the sensor's value.

\subsection{SERVICE REQUESTS}

The acceptance criteria for the service request (SR) are contained in the description of the SR. The test director will have available a copy of the service request for viewing. 


\section{TEST PROCEDURES}

\subsection{GENERAL}

\subsubsection{Startup}

Note: The Test Director prior to witness testing may have completed this test.

\begin{tabular}{|l|l|l|l|}
\hline Step & \multicolumn{1}{|c|}{ Perform } & \multicolumn{1}{c|}{ Verify } & Initial \\
\hline 1. & Start TMACS & $\begin{array}{l}\text { Verify the TMACS starts up (approximately four } \\
\text { minutes) and verify the following: }\end{array}$ & $\begin{array}{l}0 . R . \\
\text { On the TMACS screen, } \\
\text { type Control-Y }\end{array}$ \\
. & $\begin{array}{l}\text { A message is displayed indicating what days } \\
\text { worth of data is being recovered. } \\
\text { t2-user 'User' to be }\end{array}$ & $\begin{array}{l}\text { A status bar is displayed indicating what } \\
\text { percentage of the days readings have been } \\
\text { read into memory. }\end{array}$ & \\
$\begin{array}{l}\text { Edit the 'Password' to be } \\
\text { the password for t2-user } \\
\text { Edit the 'G2 } \\
\text { be t2-user }\end{array}$ & & \\
\hline
\end{tabular}

\subsubsection{Security}

\subsubsection{Telewindows ${ }^{(i)}$ Session}

\begin{tabular}{|c|c|c|c|}
\hline Step & Action & $\begin{array}{rr} & \text { Verify } \\
\end{array}$ & Initial \\
\hline 1. & $\begin{array}{l}\text { On the TMACS screen, } \\
\text { type Control-Y. }\end{array}$ & $\begin{array}{l}\text { Verify that the user mode selection workspace } \\
\text { appears on the screen with " } \mathrm{t} 2 \text {-user" in the name } \\
\text { field. }\end{array}$ & $\begin{array}{l}0 . R_{1} \\
3 / 29 / 49\end{array}$ \\
\hline 2. & $\begin{array}{l}\text { Edit the 'G2 }{ }^{\infty} \text { user mode' to } \\
\text { be something other than } \\
\text { t2-user or shut down. } \\
\text { (i.e. "administrator".) } \\
\text { Click on the END button in } \\
\text { the user mode selection } \\
\text { workspace. }\end{array}$ & $\begin{array}{l}\text { Verify that TMACS does not enter selected } \\
\text { mode. }\end{array}$ & $\begin{array}{l}0.2 \\
3 / 29 / 99\end{array}$ \\
\hline 3. & $\begin{array}{l}\text { Edit the 'G2 } 2^{\circ} \text { user mode' to } \\
\text { be "t2-user" and click on } \\
\text { the END button. }\end{array}$ & $\begin{array}{l}\text { Verify that the user mode selection workspace } \\
\text { disappears from the screen (indicating a } \\
\text { successful login). }\end{array}$ & $\begin{array}{l}0.12 \\
3 / 29 / 99\end{array}$ \\
\hline
\end{tabular}


HNF-4368, Rev. 0

\subsubsection{Central Console}

\begin{tabular}{|l|l|l|l|}
\hline Step & \multicolumn{1}{|c|}{ Action } & \multicolumn{1}{c|}{ Verify } & \multicolumn{1}{|c|}{ Initial } \\
\hline 1. & $\begin{array}{l}\text { On the TMACS screen, } \\
\text { type Control-Y. }\end{array}$ & $\begin{array}{l}\text { Verify that the user mode selection workspace } \\
\text { appears on the screen with "t2-user" in the } \\
\text { name field. }\end{array}$ & $\begin{array}{l}0.2 \\
3 / 29 / 99\end{array}$ \\
\hline 2. & $\begin{array}{l}\text { Edit the 'G2 } 2^{\infty} \text { user mode' to } \\
\text { be something other than } \\
\text { t2-user or shut down. } \\
\text { (i.e. "administrator".) }\end{array}$ & $\begin{array}{l}\text { Verify that TMACS does not enter selected } \\
\text { mode. }\end{array}$ & $\begin{array}{l}0 . R . \\
3 / 29 / 99\end{array}$ \\
\hline 3. & $\begin{array}{l}\text { Edick on the END button. } \\
\text { be "t2-user" and click on } \\
\text { the END button. }\end{array}$ & $\begin{array}{l}\text { Verify that the user mode selection workspace } \\
\text { disappears from the screen (indicating a } \\
\text { successful login). }\end{array}$ & $\begin{array}{l}0.2 . \\
3 / 29 / 99\end{array}$ \\
\hline
\end{tabular}

\subsection{GRAPHICS}

This section is performed after the system has been started and the clock is functional. This test should be performed on both the main console and Telewindows ${ }^{(*)}$.

\subsubsection{T2-User Abilities within TMACS}

\subsubsection{Central Console or Telewindows ${ }^{(\dot{2})}$}

\begin{tabular}{|c|c|c|c|}
\hline Step & Action & Verify & Initial \\
\hline & ঝ & Marn Sisplay & \\
\hline 1. & $\begin{array}{l}\text { Click on the Show Main } \\
\text { Display button on the } \\
\text { Control Panel. }\end{array}$ & $\begin{array}{l}\text { Verify that the following workspaces appear on } \\
\text { the screen: } \\
\text { - Control Panel. } \\
\text { - Monitored Systems } \\
\text { - Most Recent Alarm. } \\
\text { - Hanford Tank Farm Facilities } \\
\text { Note: Working window (may appear if Data } \\
\text { Recovery is still running) }\end{array}$ & $\begin{array}{l}O \cdot R . \\
3 / 29 / 99\end{array}$ \\
\hline 2. & $\begin{array}{l}\text { Attempt to move each of } \\
\text { the following: } \\
\text { - Workspaces } \\
\text { - Date and time display. } \\
\text { - Labels (workspace title, } \\
\text { farm and tank) } \\
\text { - Farm backgrounds } \\
\text { - Tank icons } \\
\text { GOTO button on the Most }\end{array}$ & Verify that they do not move. & $\begin{array}{l}O \cdot R . \\
3 / 29 / 99\end{array}$ \\
\hline
\end{tabular}


HNF-4368, Rev. 0

\begin{tabular}{|c|c|c|c|}
\hline Step & Action & Verify & Initial \\
\hline & Recent Alarm workspace. & & \\
\hline 3. & $\begin{array}{l}\text { Click anywhere in the } \\
\text { empty space on each } \\
\text { workspace. }\end{array}$ & Verify that no menus appear. & $\begin{array}{l}0 . R \\
3 / 22 / 99\end{array}$ \\
\hline /. & : & Tanl Staus Display : & \\
\hline 4. & $\begin{array}{l}\text { Click on the tank icon for } \\
\text { any active tank. }\end{array}$ & Verify that the Tank Status workspace appears. & $\begin{array}{l}0.12 \\
3 / 22 / 99\end{array}$ \\
\hline 5. & $\begin{array}{l}\text { Click on the Shrink } \\
\text { Window button on the } \\
\text { Tank Status workspace. }\end{array}$ & Verify that the workspace size is reduced. & $\begin{array}{l}0.12 \\
3 / 29 / 99\end{array}$ \\
\hline 6. & $\begin{array}{l}\text { Move by dragging the } \\
\text { Tank Status Window. }\end{array}$ & $\begin{array}{l}\text { Verify that the workspace moves; verify that no } \\
\text { part of the workspace can be moved off-screen. }\end{array}$ & $\begin{array}{l}0.12 \\
3 / 29 / 89\end{array}$ \\
\hline 7. & $\begin{array}{l}\text { Attempt to move several } \\
\text { objects chosen at random } \\
\text { on the Tank Status } \\
\text { workspace by doing a } \\
\text { click-and-drag. }\end{array}$ & Verify that none of the objects move. & $\begin{array}{l}0 . R \\
3 / 29 / 99\end{array}$ \\
\hline 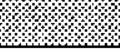 & & Senser Trend Display & \\
\hline 8. & $\begin{array}{l}\text { Click on the digital display } \\
\text { for any sensor. }\end{array}$ & $\begin{array}{l}\text { Verify that the trend workspace for that sensor } \\
\text { appears. }\end{array}$ & $\begin{array}{l}0 . R \\
3 / 29 / 99\end{array}$ \\
\hline 9. & $\begin{array}{l}\text { Click at random at several } \\
\text { places on the trend } \\
\text { workspace. }\end{array}$ & Verify that no menu appears. & $\begin{array}{l}0.12 \\
3 / 29 / 99\end{array}$ \\
\hline 10. & $\begin{array}{l}\text { Attempt to move several } \\
\text { objects chosen at random } \\
\text { on the trend workspace. }\end{array}$ & Verify that none move. & $\begin{array}{l}0 . R \\
3 / 29 / 99\end{array}$ \\
\hline 11. & $\begin{array}{l}\text { Click on the Hide } \\
\text { Workspace button on the } \\
\text { trend workspace. }\end{array}$ & Verify that the workspace disappears. & $\begin{array}{l}0.12 \\
3 / 29 / 99\end{array}$ \\
\hline & & Control Panel: & \\
\hline 12. & $\begin{array}{l}\text { Move Tank Status over a } \\
\text { portion of the Control } \\
\text { Panel workspace. } \\
\text { Click on the background of } \\
\text { the Control Panel } \\
\text { workspace. }\end{array}$ & $\begin{array}{l}\text { Verify that doing so brings the Control Panel to } \\
\text { the top. }\end{array}$ & $\begin{array}{l}0 . R \\
3 / 29 / 99\end{array}$ \\
\hline 13. & $\begin{array}{l}\text { Click on the Hide Window } \\
\text { button on the Tank Status } \\
\text { workspace. }\end{array}$ & Verify that the workspace disappears. & $\begin{array}{l}0 . R \\
3 / 29 / 99\end{array}$ \\
\hline 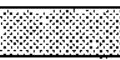 & 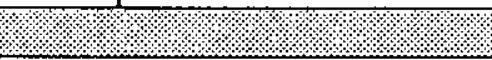 & Monitored Systens & \\
\hline 14. & $\begin{array}{l}\text { Click on any of the button } \\
\text { on the MONITORED } \\
\text { SYSTEMS workspace. }\end{array}$ & $\begin{array}{l}\text { Verify that the monitored system chosen } \\
\text { workspace appears. }\end{array}$ & $\begin{array}{l}0.12 \\
3 / 29 / 99\end{array}$ \\
\hline 15. & Click at random at several & Verify that no menu appears. & $0.8 \cdot 3 / 29 / 98$ \\
\hline
\end{tabular}


HNF-4368, Rev. 0

\begin{tabular}{|c|c|c|c|}
\hline Step & Action & Verify & Initial \\
\hline & places on the workspace. & & \\
\hline 16. & $\begin{array}{l}\text { Attempt to move several } \\
\text { objects chosen at random } \\
\text { on the workspace. }\end{array}$ & Verify that none move. & $\begin{array}{c}0.12 \\
3 / 24 / 99\end{array}$ \\
\hline 17. & $\begin{array}{l}\text { Click on the Hide Window } \\
\text { button on the workspace. }\end{array}$ & Verify that the workspace disappears. & $\begin{array}{c}0.12 \\
3 / 29 / 99\end{array}$ \\
\hline
\end{tabular}

\subsubsection{Central Console Only}

\begin{tabular}{|c|c|c|c|}
\hline Step & Action & Verify & Initial \\
\hline 1. & $\begin{array}{l}\text { Click on the Show Main } \\
\text { Display button on the } \\
\text { Control Panel. }\end{array}$ & $\begin{array}{l}\text { Verify that the following workspaces appear on } \\
\text { the screen: } \\
\text { - Control Panel. } \\
\text { - Monitored Systems } \\
\text { - Most Recent Alarm. } \\
\text { - Hanford Tank Farm Facilities } \\
\text { Note: Working window may appear if Data } \\
\text { Recovery is still running. }\end{array}$ & $\begin{array}{l}O . R \\
3 / 29 / 99\end{array}$ \\
\hline 2. & $\begin{array}{l}\text { Click on the tank icon for } \\
\text { any active tank. }\end{array}$ & Verify that the Tank Status workspace appears. & $\begin{array}{l}0.12 \\
3 / 29199\end{array}$ \\
\hline \multicolumn{4}{|c|}{ Wse Selectrble Trends . } \\
\hline 3. & $\begin{array}{l}\text { Click on a TREND } \\
\text { GRAPH button (located at } \\
\text { the bottom of the Tank } \\
\text { Workspace). }\end{array}$ & $\begin{array}{l}\text { Verify that a User Configurable Trend Graph } \\
\text { workspace appears. }\end{array}$ & $\begin{array}{l}0.12 \\
3 / 27 / 99\end{array}$ \\
\hline 4. & $\begin{array}{l}\text { Click at random at several } \\
\text { places on the Trend Graph } \\
\text { workspace. }\end{array}$ & Verify that no menu appears. & $\begin{array}{l}0.12 . \\
3 / 2 q / 99\end{array}$ \\
\hline 5. & $\begin{array}{l}\text { Attempt to move several } \\
\text { objects chosen at random } \\
\text { on the Trend Graph } \\
\text { workspace }\end{array}$ & Verify that no objects move. & $\begin{array}{l}0.12 \\
3 / 29 / 99\end{array}$ \\
\hline 6. & $\begin{array}{l}\text { Click on the Hide Window } \\
\text { button on the Trend Graph } \\
\text { workspace. }\end{array}$ & Verify that the workspace disappears. & $\begin{array}{l}0 \cdot 2 . \\
3 / 29 / 99\end{array}$ \\
\hline 7. & $\begin{array}{l}\text { Click on the Hide Window } \\
\text { button on the Tank Status } \\
\text { workspace. }\end{array}$ & Verify that the workspace disappears. & $\begin{array}{l}0 \cdot R \\
3 / 22 / 99\end{array}$ \\
\hline 誉 & (1, & (6urent Vlarns . & \\
\hline 8. & $\begin{array}{l}\text { Click on the CURRENT } \\
\text { ALARMS button on the } \\
\text { Control Panel. }\end{array}$ & $\begin{array}{l}\text { Verify that the Current Alarms workspace } \\
\text { appears. }\end{array}$ & $\begin{array}{l}0.12 \\
3 / 29 / 99\end{array}$ \\
\hline 9. & $\begin{array}{l}\text { Click at random at several } \\
\text { places on the Current } \\
\text { Alarms workspace. }\end{array}$ & Verify that no menu appears. & $\begin{array}{l}0.12 \\
3 / 29 / 99\end{array}$ \\
\hline
\end{tabular}


HNF-4368, Rev. 0

\begin{tabular}{|l|l|l|l|}
\hline Step & \multicolumn{1}{|c|}{ Action } & \multicolumn{1}{c|}{ Verify } & Initial \\
\hline 10. & $\begin{array}{l}\text { Attempt to move several } \\
\text { objects chosen at random } \\
\text { on the Current Alarms } \\
\text { workspace. }\end{array}$ & Verify that none move. & $\begin{array}{l}0.2 . \\
3 / 29 / 99\end{array}$ \\
\hline 11. & $\begin{array}{l}\text { Click on the Hide Window } \\
\text { button on the Current } \\
\text { Alarms workspace. }\end{array}$ & Verify that the workspace disappears. & $\begin{array}{c}0.2 . \\
3 / 29 / 99\end{array}$ \\
\hline
\end{tabular}

\subsubsection{Control Panel}

\subsubsection{Operation of the SHOW MAIN DISPLAY button}

\begin{tabular}{|c|c|c|c|}
\hline Step & Perform & Expected Result & Initial \\
\hline 1. & $\begin{array}{l}\text { Click on any enabled Tank } \\
\text { Icon in the Hanford Tank } \\
\text { Farm Facilities. (The icon } \\
\text { will not be gray.) If the } \\
\text { Tank Status Window is not } \\
\text { already shrunk then click } \\
\text { it's Shrink Window button } \\
\text { (an } \nabla \text { as a symbol). }\end{array}$ & $\begin{array}{l}\text { Verify that a Tank Status workspace appears } \\
\text { for the selected tank and that the Control Panel } \\
\text { is visible. }\end{array}$ & $\begin{array}{l}0 . R \\
3 / 29 / 99\end{array}$ \\
\hline 2. & $\begin{array}{l}\text { Click on the Show Main } \\
\text { Display button on the } \\
\text { Control Panel. }\end{array}$ & $\begin{array}{l}\text { Verify that the Tank Status workspace } \\
\text { disappears. } \\
\text { Verify that the following workspaces appear on } \\
\text { the screen: } \\
\text { - Hanford Tank Farm Facilities } \\
\text { - Control Panel } \\
\text { - Most Recent Alarm (may be partially } \\
\text { covered by the Hanford Tank Farm } \\
\text { Facilities workspace) } \\
\text { - Monitored Systems } \\
\text { Note: Working window may appear if Data } \\
\text { Recovery is still running. }\end{array}$ & $\begin{array}{l}0.12 \\
3 / 29 / 99\end{array}$ \\
\hline \multirow[t]{2}{*}{3} & $\begin{array}{l}\text { Examine the TMACS } \\
\text { display. }\end{array}$ & $\begin{array}{l}\text { Verify that the Control Panel workspace is } \\
\text { located in the upper right-hand corner. }\end{array}$ & $\begin{array}{l}0.21 \\
3 / 28 / 99\end{array}$ \\
\hline & & $\begin{array}{l}\text { Verify that the following objects appear in the } \\
\text { workspace in order, top to bottom: } \\
\text { - Label "Control Panel" } \\
\text { - SHOW MAIN DISPLAY button } \\
\text { - CURRENT ALARMS button (Not } \\
\text { - } \text { available to Telewindows sessions) } \\
\text { - Number of Current Alarms digital display } \\
\text { - PRE SENSOR TRENDS button } \\
\text { PRINT SCREEN button (Not available to }\end{array}$ & $\begin{array}{l}0.12 \\
3 / 29 / 99\end{array}$ \\
\hline
\end{tabular}


HNF-4368, Rev. 0

\begin{tabular}{|c|c|c|c|}
\hline Step & Perform & Expected Result & Initial \\
\hline & & $\begin{array}{l}\text { Telewindows } \\
\text { - A date and time display } \\
\end{array}$ & $\begin{array}{l}0.12 \\
3 / 28 / 29\end{array}$ \\
\hline & & $\begin{array}{l}\text { Verify that MONITORED SYSTEMS } \\
\text { workspace is displayed on the middle right- } \\
\text { hand side of the screen and is displaying the } \\
\text { following: } \\
\text { - AY/AZ Exhauster } \\
\text { - C-106 Sluicing } \\
\text { - K-Basins }\end{array}$ & $\begin{array}{l}0 \cdot \pi \\
3 / 29 / 89\end{array}$ \\
\hline & & $\begin{array}{l}\text { Verify that the Most Recent Alarm workspace } \\
\text { is in the lower right-hand corner and that the } \\
\text { GOTO button appears at the top center of the } \\
\text { workspace. }\end{array}$ & $\begin{array}{l}0 \cdot n \\
3 / 22 / 99\end{array}$ \\
\hline & & $\begin{array}{l}\text { Verify that the Number of Current Alarms } \\
\text { digital display is located at the top right of the } \\
\text { Most Recent Alarm workspace. }\end{array}$ & 0.21. \\
\hline & & $\begin{array}{l}\text { Verify that the Hanford Tank Farm Facilities } \\
\text { workspace occupies the left portion of the } \\
\text { screen. }\end{array}$ & $\begin{array}{l}0.12 \\
3 / 2 q / 9 q\end{array}$ \\
\hline & & $\begin{array}{l}\text { Verify that a brown background appears behind } \\
\text { these workspaces and that no other workspaces } \\
\text { are visible. }\end{array}$ & $\begin{array}{l}0.21 \\
3 / 29 / 29\end{array}$ \\
\hline
\end{tabular}

\subsubsection{Operation of CURRENT ALARMS Button and Screen}

Note: The CURRENT ALARMS button is not available in a Telewindows ${ }^{(3)}$ session.

\begin{tabular}{|c|c|c|c|}
\hline Step & Perform & $\begin{array}{c}\text { Expected Result } \\
\end{array}$ & Initial \\
\hline 1. & $\begin{array}{l}\text { Click on the CURRENT } \\
\text { ALARMS button. }\end{array}$ & $\begin{array}{l}\text { Verify that the Current Alarms workspace } \\
\text { appears on the left-hand side of the screen and } \\
\text { contains the following: } \\
\text { - HIDE WINDOW (with an } x \text { as a symbol) } \\
\text { - SHRINK WINDOW (an as a symbol) } \\
\text { - EXPAND WINDOW (an as a symbol) } \\
\text { - CURRENT-ALARMS title box } \\
\text { - UP ONE ALARM } \\
\text { - UP ONE PAGE } \\
\text { - REFRESH ALARMS } \\
\text { - } \text { DOWN ONE PAGE } \\
\text { - } \text { DOWN ONE ALARM TO TOP of LIST } \\
\text { - GO TO END of LIST } \\
\text { - ACKNOWLEDGE ALL WHITE }\end{array}$ & $\begin{array}{l}0.12 \\
3 / 29 / 99\end{array}$ \\
\hline
\end{tabular}



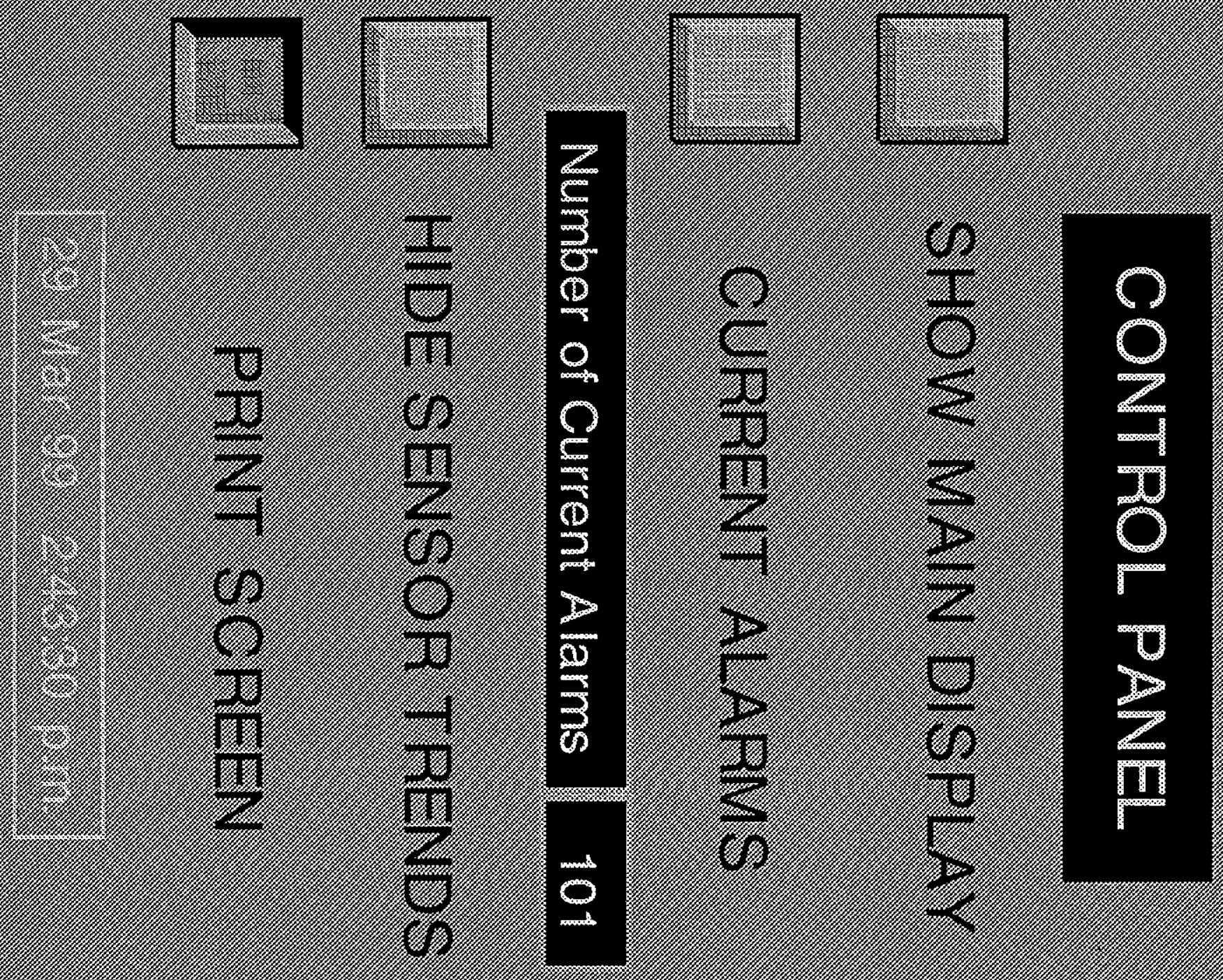

$$
\text { Section 6.2.2.4 3/29/99 }
$$


HNF-4368, Rev. 0

\begin{tabular}{|c|c|c|c|}
\hline Step & Perform & Expected Result & Initial \\
\hline & & $\begin{array}{l}\text { ALARMS } \\
\text { - ACKNOWLEDGE ALL BLUE } \\
\text { MESSAGES }\end{array}$ & $\begin{array}{l}0 . R \\
3 / 29 / 99\end{array}$ \\
\hline \multicolumn{4}{|c|}{ (: } \\
\hline 2. & $\begin{array}{l}\text { Note: If the Current } \\
\text { Alarms workspace is } \\
\text { already shrunk then } \\
\text { expand first. } \\
\text { Click on the SHRINK } \\
\text { WINDOW button in the } \\
\text { Current Alarms } \\
\text { workspace. }\end{array}$ & $\begin{array}{l}\text { Verify the Current Alarms workspace: } \\
\text { - Decreases in size } \\
\text { - Moves to the left-hand side of the screen } \\
\text { - Has space to show } 10 \text { alarms. (Only } \\
9 \text { alarms will be visible if the first alarm in } \\
\text { the list is visible.) }\end{array}$ & $\begin{array}{l}3 \cdot R \\
3 / 2 q / 99\end{array}$ \\
\hline \multicolumn{4}{|c|}{ 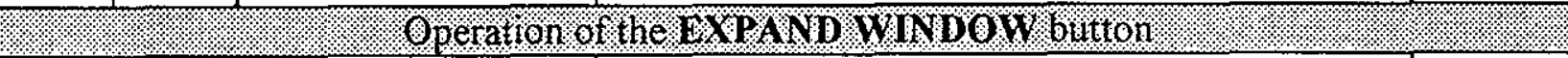 } \\
\hline 3. & $\begin{array}{l}\text { Click on the EXPAND } \\
\text { WINDOW button in the } \\
\text { Current Alarms } \\
\text { workspace. }\end{array}$ & $\begin{array}{l}\text { Verify the Current Alarms workspace: } \\
\text { - Increases in size } \\
\text { - Moves to the left-hand side of the screen } \\
\text { - Has space to show } 6 \text { alarms. (Only } \\
5 \text { alarms will be visible if the first alarm in } \\
\text { the list is visible.) }\end{array}$ & $\begin{array}{l}0.12 . \\
3 / 29 / 99\end{array}$ \\
\hline \multicolumn{4}{|c|}{ (3) } \\
\hline 4. & $\begin{array}{l}\text { Click on the HIDE } \\
\text { WINDOW button in the } \\
\text { Current Alarms } \\
\text { workspace. }\end{array}$ & Verify that the workspace disappears & $\begin{array}{l}0.12 . \\
3 / 29 / 99\end{array}$ \\
\hline
\end{tabular}

\subsubsection{Operation of the HIDE SENSOR TRENDS button}

\begin{tabular}{|c|c|c|c|}
\hline Step & Perform & Expected Result & Initial \\
\hline 1. & $\begin{array}{l}\text { Click on an enabled Tank. } \\
\text { Icon on the Hanford Tank } \\
\text { Farm Facilities workspace. } \\
\text { (The icon will not be gray.) }\end{array}$ & $\begin{array}{l}\text { Verify that the Tank Status workspace for this } \\
\text { tank appears. }\end{array}$ & $\begin{array}{l}0.12 . \\
3 / 29 / 99\end{array}$ \\
\hline 2. & $\begin{array}{l}\text { Click on several sensor } \\
\text { trend icons selected at } \\
\text { random. }\end{array}$ & $\begin{array}{l}\text { Verify that Sensor Trend workspaces for the } \\
\text { selected sensors appear. }\end{array}$ & $\begin{array}{l}0.12 \\
3 / 29 / 99\end{array}$ \\
\hline 3. & $\begin{array}{l}\text { Lift the Control Panel to } \\
\text { the top by clicking in the } \\
\text { blank background on the } \\
\text { Control Panel workspace. } \\
\text { Click on the HIDE } \\
\text { SENSOR TRENDS button } \\
\text { on the Control Panel. }\end{array}$ & $\begin{array}{l}\text { Verify that the Tank Status workspace and any } \\
\text { Sensor Trend workspaces are hidden. }\end{array}$ & $\begin{array}{l}0 . R \\
9 / 28 / 89\end{array}$ \\
\hline
\end{tabular}


HNF-4368, Rev. 0

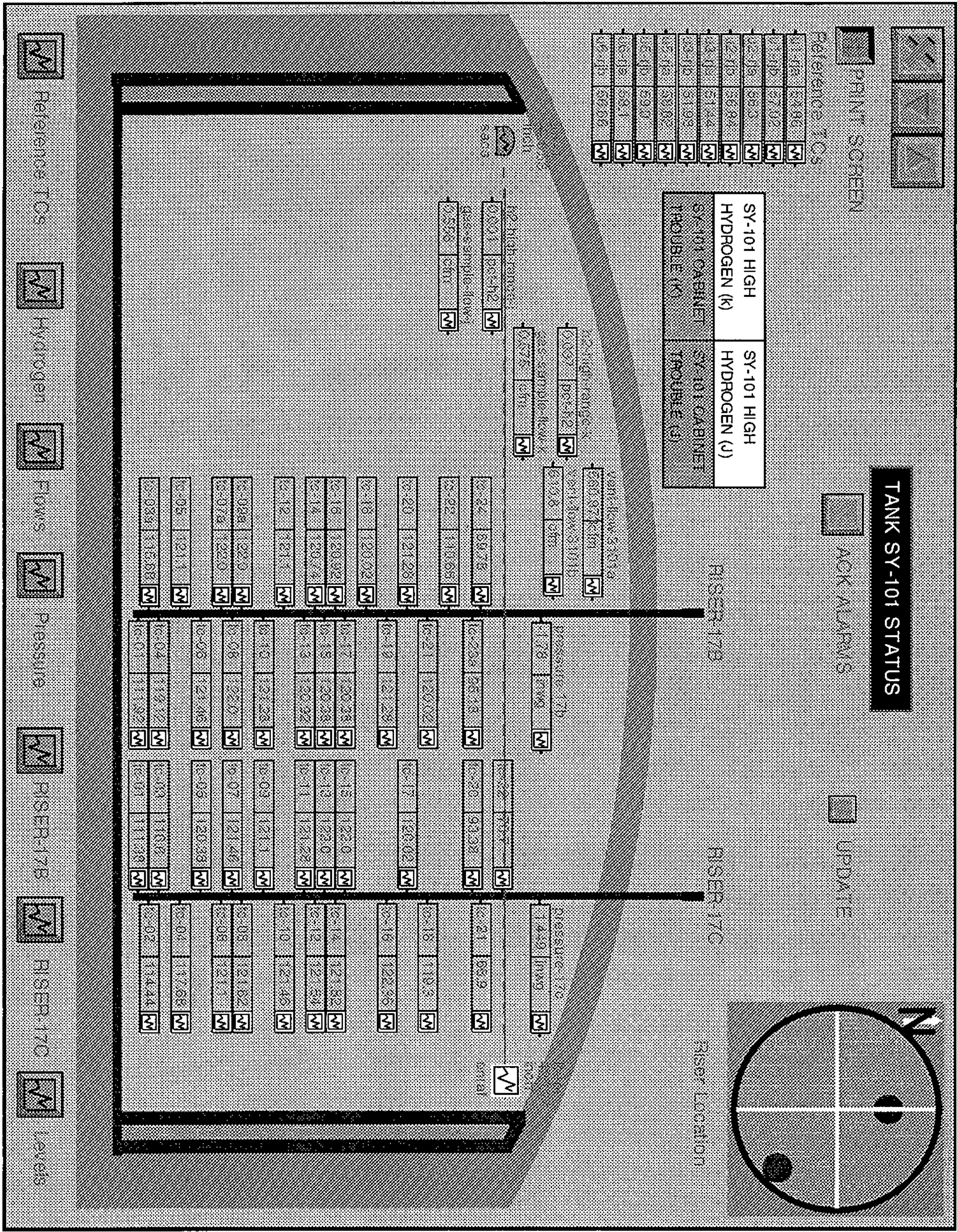

Section-6.2.3.1 STep 4 3/29/99 
HNF-4368, Rev. 0

\subsubsection{Operation of the PRINT SCREEN button}

Note: The CURRENT ALARMS button is not available in a Telewindows ${ }^{\text {session. }}$

\begin{tabular}{|l|l|l|l|}
\hline Step & \multicolumn{1}{|c|}{ Perform } & \multicolumn{1}{|c|}{ Expected Result } & Initial \\
\hline 1. & $\begin{array}{l}\text { Click on the PRINT } \\
\text { SCREEN button }\end{array}$ & $\begin{array}{l}\text { Verify that the Control Panel workspace is } \\
\text { printed. }\end{array}$ & $\begin{array}{l}0.2 . \\
3 / 2 q / 99\end{array}$ \\
\hline
\end{tabular}

\subsubsection{Hanford Tank Farm Facility}

\subsubsection{Operation of a TANK ICON button}

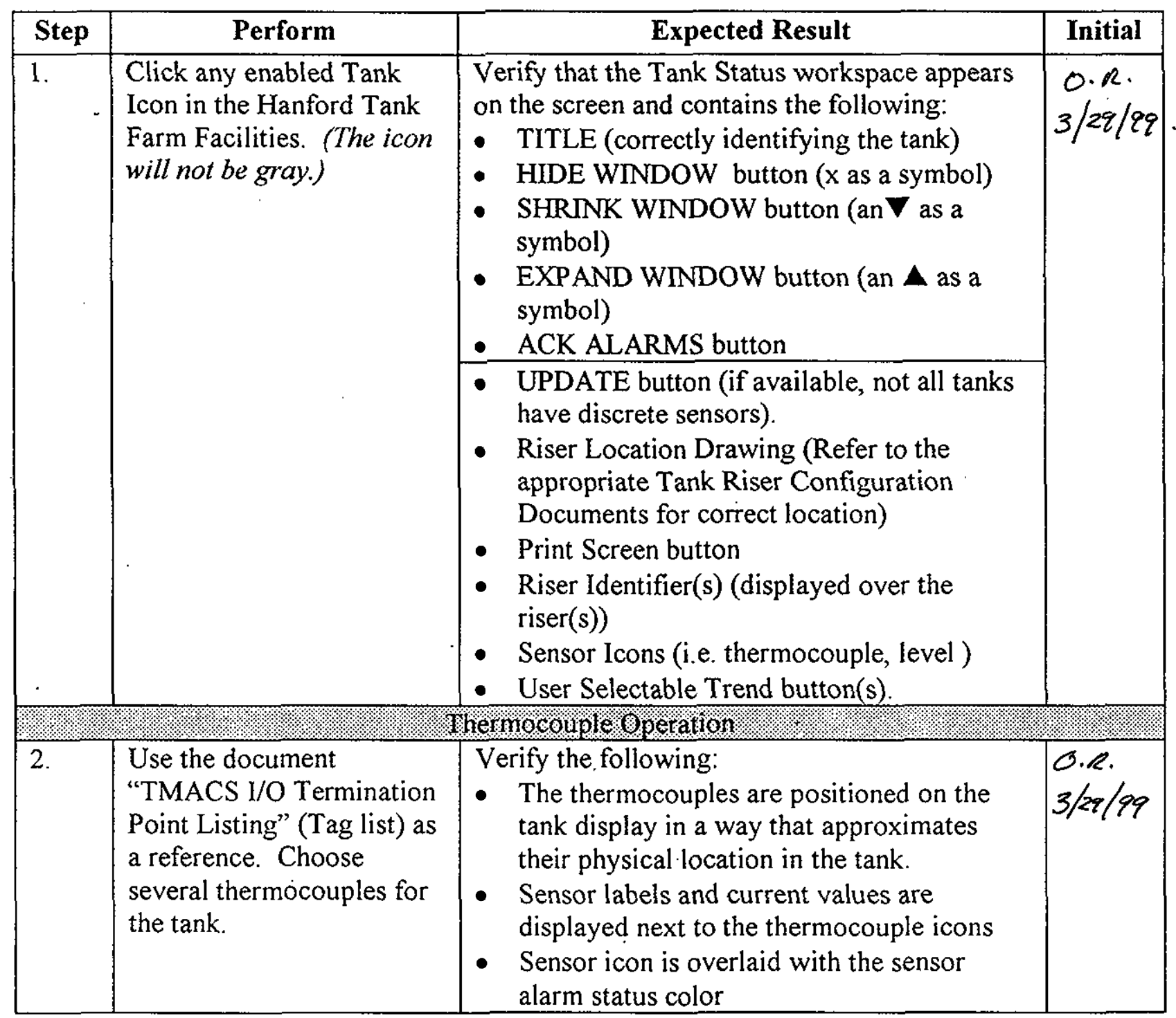


HNF-4368, Rev. 0

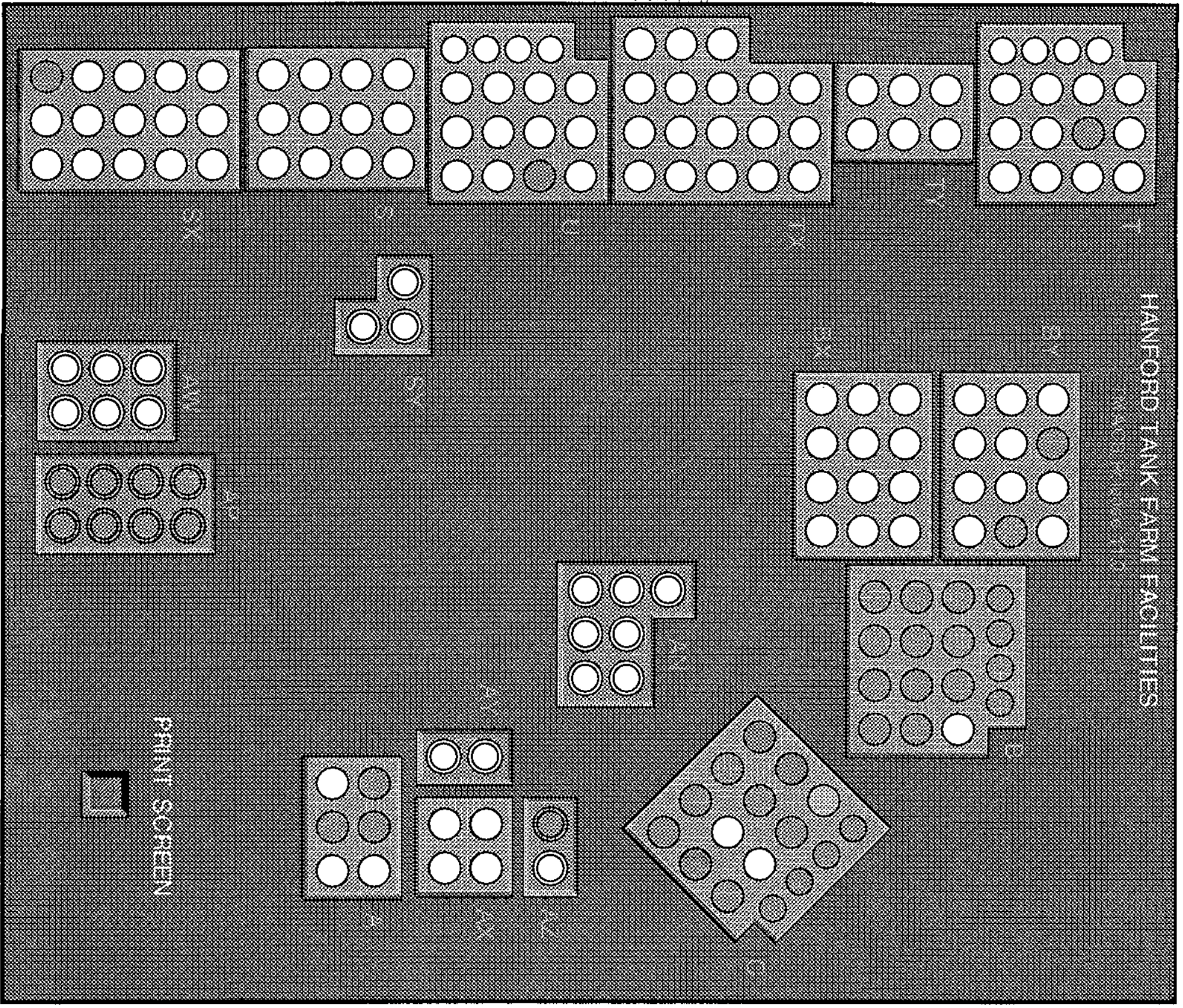

Section 6.2.9 3/29/99 
HNF-4368, Rev. 0

\begin{tabular}{|c|c|c|c|}
\hline Step & Perform & Expected Result & Initial \\
\hline \multicolumn{4}{|c|}{ 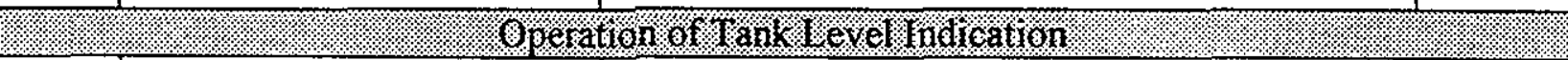 } \\
\hline 3. & & $\begin{array}{l}\text { Verify the following: } \\
\text { - The surface level icon(s) is positioned } \\
\text { proportionally to the maximum tank height } \\
\text { and at the current level displayed by the } \\
\text { reading. } \\
\text { - Sensor labels and current values are } \\
\text { displayed next to the surface level icons } \\
\text { The label should identifying the source of } \\
\text { this reading. (ENRAF or SACS) } \\
\text { - Sensor icon is overlaid with the sensor } \\
\text { alarm status color }\end{array}$ & $\begin{array}{l}0.12 \\
3 / 2 q / 99\end{array}$ \\
\hline \multicolumn{4}{|c|}{ 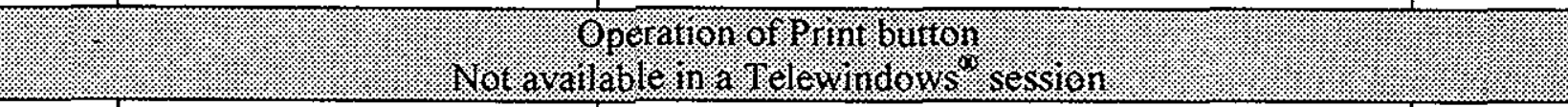 } \\
\hline 4. & $\begin{array}{l}\text { Click on the PRINT } \\
\text { SCREEN button. }\end{array}$ & Verify that the tank workspace prints. & $\begin{array}{l}0.12 \\
3 / 29 / 99\end{array}$ \\
\hline \multicolumn{4}{|c|}{ 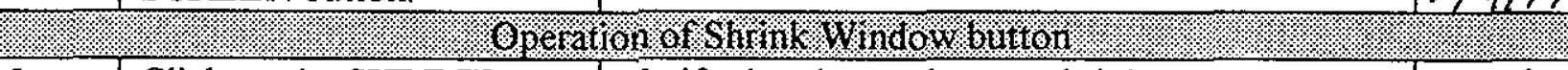 } \\
\hline 5. & $\begin{array}{l}\text { Click on the SHRINK } \\
\text { WINDOW button (an } \nabla \text { as } \\
\text { a symbol). }\end{array}$ & Verify that the workspace shrinks. & $\begin{array}{l}0.12 \\
3 / 29 / 99\end{array}$ \\
\hline 6. & $\begin{array}{l}\text { Drag the Tank Status } \\
\text { workspace to the upper } \\
\text { right hand corner. }\end{array}$ & $\begin{array}{l}\text { Verify that the Tank Status workspace stops at } \\
\text { the edge of the screen when dragged to the top } \\
\text { or to the right. }\end{array}$ & $\begin{array}{l}0.2 . \\
3 / 29 / 99\end{array}$ \\
\hline \multicolumn{4}{|c|}{ (3. } \\
\hline 7. & $\begin{array}{l}\text { Click on the EXPAND } \\
\text { WINDOW button (an } \\
\text { as a symbol). }\end{array}$ & Verify that the workspace enlarges. & $\begin{array}{l}0.12 \\
3 / 29 / 99\end{array}$ \\
\hline \multicolumn{4}{|c|}{ Operation of the WISE Guttron : } \\
\hline 8. & $\begin{array}{l}\text { Click on the HIDE } \\
\text { WINDOW. }\end{array}$ & Verify that the workspace is hidden. & $\begin{array}{l}0.12 \\
3 / 29 / 99\end{array}$ \\
\hline \multicolumn{4}{|c|}{$\begin{array}{l}\text { Note: Operation of the Acknowledge Alarm button is performed in section 0. (Error! Not a } \\
\text { valid result for table.) }\end{array}$} \\
\hline \multicolumn{4}{|c|}{ Note: Operation of the Trends is performed in section 6.3 (Trending). } \\
\hline
\end{tabular}

\subsubsection{Operation Of The Print Button}

Note: The CURRENT ALARMS button is not available in a Telewindows ${ }^{(k)}$ session.

\begin{tabular}{|l|l|l|c|}
\hline Step & \multicolumn{1}{|c|}{ Perform } & \multicolumn{1}{|c|}{ Expected Result } & Initial \\
\hline 1. & $\begin{array}{l}\text { Click on the PRINT } \\
\text { SCREEN button in the } \\
\text { lower right hand corner of } \\
\text { workspace. (May have to }\end{array}$ & Verify that the workspace is printed . & $\begin{array}{l}\text { O.R. } \\
3 / 29 / 99\end{array}$ \\
\hline
\end{tabular}




\begin{tabular}{|c|l|c|c|}
\hline Step & \multicolumn{1}{|c|}{ Perform } & Expected Result & Initial \\
\hline $\begin{array}{l}\text { click on HTTF workspace } \\
\text { to see button) }\end{array}$ & & $\begin{array}{c}0.2 . \\
3 / 2 q / 97\end{array}$ \\
\hline
\end{tabular}

\subsubsection{Monitored Systems}

\subsubsection{Operation Of The Monitored System Button}

\begin{tabular}{|c|c|c|c|}
\hline Step & Perform & Expected Result & Initial \\
\hline 1. & $\begin{array}{l}\text { Click on the any system } \\
\text { displayed on the } \\
\text { MONITORED SYSTEMS } \\
\text { workspace. }\end{array}$ & $\begin{array}{l}\text { Verify that a workspace is displayed } \\
\text { representing the monitored system. }\end{array}$ & $\begin{array}{l}0.12 \\
3 / 29 / 99\end{array}$ \\
\hline 2. & $\begin{array}{l}\text { Click on the sensor } \\
\text { objects. }\end{array}$ & $\begin{array}{l}\text { Verify that no graphic workspaces or menu } \\
\text { boxes are displayed. }\end{array}$ & $\begin{array}{l}0.12 \\
3 / 22 / 199\end{array}$ \\
\hline 3. & $\begin{array}{l}\text { For alarm panels, click on } \\
\text { any graphic "borders". }\end{array}$ & $\begin{array}{l}\text { Verify that no graphic workspaces or menu } \\
\text { boxes are displayed. }\end{array}$ & $\begin{array}{l}0 . k \\
3 / 29 / 99\end{array}$ \\
\hline \multicolumn{4}{|c|}{ 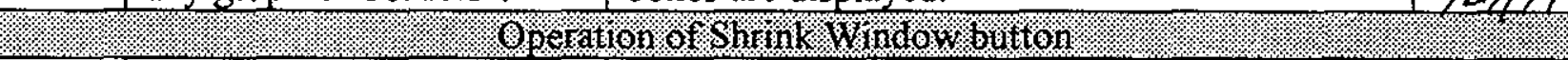 } \\
\hline & $\begin{array}{l}\text { Click on the SHRINK } \\
\text { WINDOW button (an } \nabla \text { as } \\
\text { a symbol). }\end{array}$ & Verify that the workspace shrinks. & \\
\hline & $\begin{array}{l}\text { Drag the workspace to the } \\
\text { upper right hand corner. }\end{array}$ & $\begin{array}{l}\text { Verify that the workspace stops at the edge of } \\
\text { the screen when dragged to the top or to the } \\
\text { right. }\end{array}$ & $\begin{array}{l}0 . R \\
3 / 29 / 99\end{array}$ \\
\hline \multicolumn{4}{|c|}{ 1.:. } \\
\hline & $\begin{array}{l}\text { Click on the EXPAND } \\
\text { WINDOW button (an } 4 \\
\text { as a symbol). }\end{array}$ & Verify that the workspace enlarges. & $\begin{array}{l}0.12 \\
3 / 29 / 99\end{array}$ \\
\hline \multicolumn{4}{|c|}{ 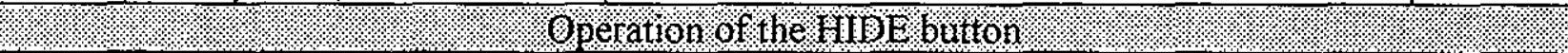 } \\
\hline & $\begin{array}{l}\text { Click on the HIDE } \\
\text { WINDOW. }\end{array}$ & Verify that the workspace is hidden. & $\begin{array}{l}0.2 \\
3 / 29 / 99\end{array}$ \\
\hline
\end{tabular}

\subsection{TRENDING}

\subsubsection{Operation of Sensor Trends}

Have the Test Director verify that the TMACS is running in Development Mode of operation and is generating variable sensor data. The steps within this test case will be performed for each of two tanks that are selected at random. Note: $\mathrm{G} 2^{\infty}$ will only display trend data that varies over time. The Test Director will place TMACS in t2-user mode.

\begin{tabular}{|l|l|l|l|}
\hline Step & \multicolumn{1}{|c|}{ Perform } & \multicolumn{1}{c|}{ Expected Result } & Initial \\
\hline 1. & $\begin{array}{l}\text { Click any enabled Tank Icon } \\
\text { in the Hanford Tank Farm } \\
\text { Facilities. (The icon will not }\end{array}$ & $\begin{array}{l}\text { Verify that a Sensor Trend workspace for the } \\
\text { sensor chosen and contains the following. } \\
\text { A graph or chart }\end{array}$ & $\begin{array}{l}0 . A . \\
3 / 2 q / 99\end{array}$ \\
\hline
\end{tabular}


HNF-4368, Rev. 0

\begin{tabular}{|c|c|c|c|}
\hline Step & Perform & Expected Result & Initial \\
\hline & $\begin{array}{l}\text { be gray.) } \\
\text { Click on the portion of any } \\
\text { sensor icon that looks like a } \\
\text { little graph. }\end{array}$ & $\begin{array}{l}\text { HIDE WINDOW button (with an } x \text { as a } \\
\text { symbol) } \\
\text { DETAIL button (upper right of the } \\
\text { workspace). }\end{array}$ & $\begin{array}{l}0.12 \\
3 / 29 / 99\end{array}$ \\
\hline 2. & Examine the Graph/Char. & $\begin{array}{l}\text { Verify the following: } \\
\text { The current value on the trend graph } \\
\text { approximates the current value on the } \\
\text { digital display. } \\
\text { The values line color is black. } \\
\text { - Lines for the low and high alarm limits } \\
\text { appear at roughly one-tenth }(1 / 10) \text { and } \\
\text { nine tenths ( } 9 / 10) \text { of the distance on the } \\
\text { vertical axis. Note: Only if trend is } \\
\text { within limits: } \\
\text { Alarm limit bands match the alarm color } \\
\text { (Yellow or Red). } \\
\text { The trend title (above) and label (below) } \\
\text { agree with the sensor tag name and } \\
\text { descriptor. } \\
\text { The time scale of the horizontal time axis } \\
\text { is } 7 \text { days and that some dates are shown. }\end{array}$ & $\begin{array}{l}O \cdot R \\
3 / 2 q / 9 q\end{array}$ \\
\hline 3. & $\begin{array}{l}\text { Click on the Sensor Detail } \\
\text { button at the upper right of } \\
\text { the Sensor Trend workspace. }\end{array}$ & $\begin{array}{l}\text { Verify the detailed information for the } \\
\text { chosen sensor is correctly displayed and } \\
\text { includes the following: } \\
\text { - Current Reading } \\
\text { - Last Good Reading At } \\
\text { - Units } \\
\text { - High Alarm Limit } \\
\text { - Low Alarm Limit } \\
\text { - Deadband } \\
\text { - Point Processing } \\
\text { - } \text { ROC Processing } \\
\text { - Polling Freq. Index } \\
\text { - Polling Freq. Sec. } \\
\text { - Validity Interval } \\
\text { - Expiration Time } \\
\text { - Formula Expression } \\
\text { - Formula Parameter } \\
\text { - Type (Temperature Only) } \\
\text { - Upper Instrument Limit } \\
\text { - Lower Instrument Limit } \\
\text { - Delta }\end{array}$ & $\begin{array}{l}O \cdot R \\
3 / 2 q / 9 q\end{array}$ \\
\hline
\end{tabular}


HNF-4368, Rev. 0

\begin{tabular}{|c|c|c|c|}
\hline Step & Perform & Expected Result & Initial \\
\hline & 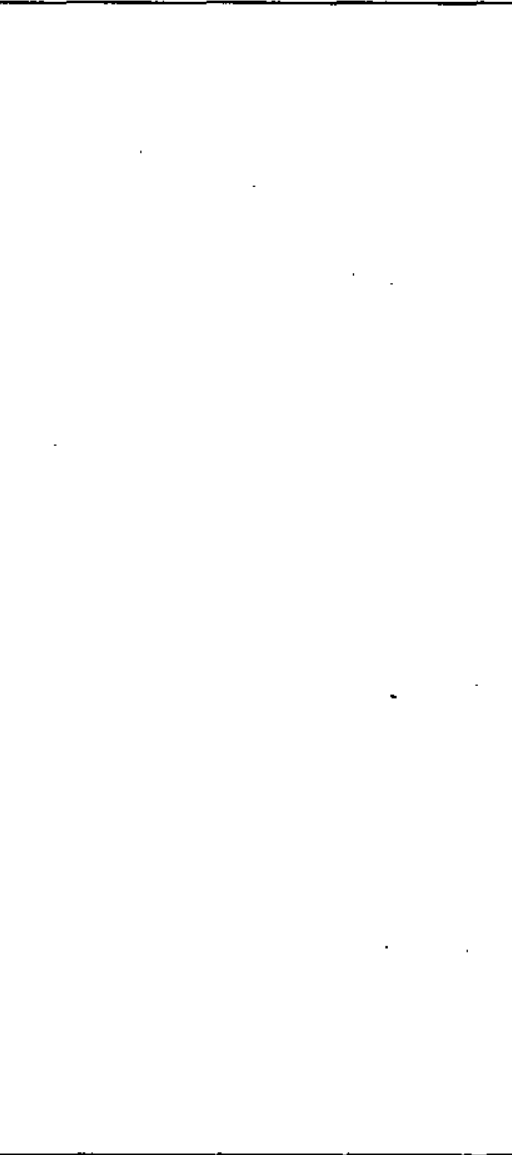 & $\begin{array}{l}\text { - } \text { Alarm Processing } \\
\text { - } \text { Logging } \\
\text { - } \text { Raw Value } \\
\text { - Station Status } \\
\text { - } \text { Current Reading } \\
\text { - } \text { Last Good Reading At } \\
\text { - Units } \\
\text { - } \text { High Alarm Limit } \\
\text { - Low Alarm Limit } \\
\text { - } \text { Deadband } \\
\text { - Point Processing } \\
\text { - ROC Processing } \\
\text { - Suspect Status } \\
\text { - Sensor Type Name } \\
\text { - } \text { Slvl_dttm } \\
\text { - } \text { Lower Instrument Limit } \\
\text { - } \text { Delta } \\
\text { - Alarm Processing } \\
\text { - Logging }\end{array}$ & $\begin{array}{l}0.2 . \\
3 / 28 / 99\end{array}$ \\
\hline 4. & $\begin{array}{l}\text { Click on the Sensor Detail } \\
\text { button at the upper right of } \\
\text { the Sensor Trend workspace. }\end{array}$ & $\begin{array}{l}\text { Verify the sensor detail information is ne } \\
\text { longer visible. updated. } \\
\text { see Excetion? }\end{array}$ & $\begin{array}{l}0.12 . \\
3 / 29 / 99\end{array}$ \\
\hline \multicolumn{4}{|c|}{ 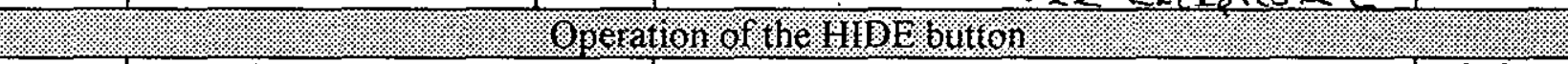 } \\
\hline 5. & $\begin{array}{l}\text { Click on the HDE } \\
\text { WINDOW button. }\end{array}$ & Verify that the workspace is hidden. & $\begin{array}{l}0.12 . \\
3 / 29 / 99\end{array}$ \\
\hline
\end{tabular}

\subsubsection{Operation of User Selectable trends}

Note: User selectable sensor trends cannot be performed in a Telewindows ${ }^{(2)}$ session.

\begin{tabular}{|c|c|c|c|}
\hline Step & Perform & Expected Result & Initial \\
\hline 1. & $\begin{array}{l}\text { Click any enabled Tank Icon } \\
\text { in the Hanford Tank Farm } \\
\text { Facilities. (The icon will not } \\
\text { be gray.) } \\
\text { Click on a USER } \\
\text { SELECTABLE TRENDS } \\
\text { button. (located at the bottom } \\
\text { of the Tank Status } \\
\text { workspace.) }\end{array}$ & $\begin{array}{l}\text { Verify that the USER SELECTABLE TRENDS } \\
\text { workspace appears and contains the following. } \\
\text { - Title (identifying what Tank trend is } \\
\text { associated with) } \\
\text { - Trend graph or chart. } \\
\text { - HIDE WINDOW button (with an } \mathrm{x} \text { as a } \\
\text { symbol) } \\
\text { - SHRINK WINDOW button (an } \nabla \text { as a } \\
\text { symbol) }\end{array}$ & $\begin{array}{l}0.12 . \\
3 / 24 / 99\end{array}$ \\
\hline
\end{tabular}


HNF-4368, Rev. 0

\begin{tabular}{|c|c|c|c|}
\hline Step & Perform & Expected Result & Initial \\
\hline- & & 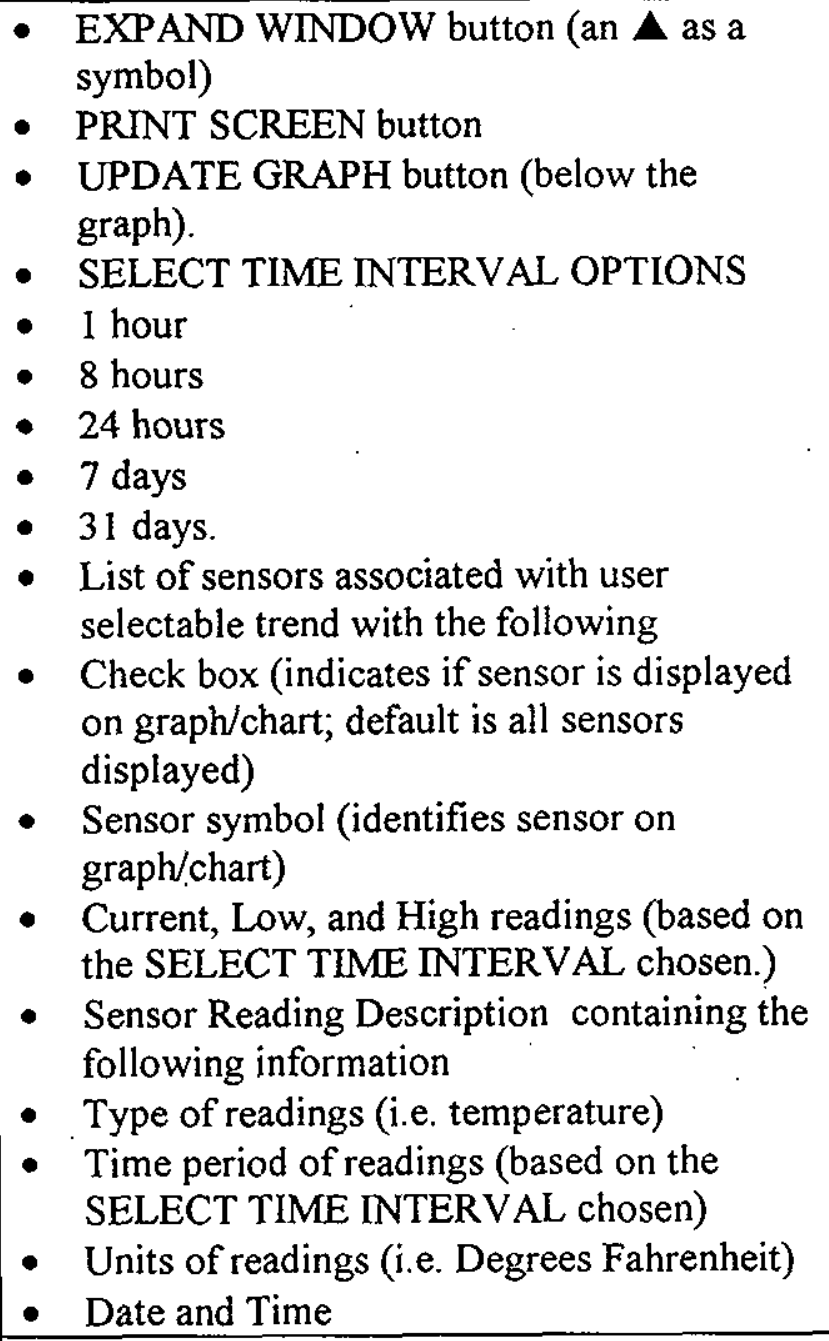 & $\begin{array}{l}0.12 \\
3 / 29 / 99\end{array}$ \\
\hline 2. & $\begin{array}{l}\text { Click on the UPDATE } \\
\text { GRAPH button }\end{array}$ & $\begin{array}{l}\text { Verify the Graph/Chart has the following: } \\
\text { - The current value for each sensor on the } \\
\text { trend graph approximates the current value } \\
\text { on the digital display. } \\
\text { The values line matches the symbol for } \\
\text { each sensor. } \\
\text { - Trend graph label (below the x-axis of the } \\
\text { graph) reads: } \\
\text { "TANK xx-yyy SELECTED SENSORS } \\
\text { INDICATED BY X" } \\
\text { Where "xx-yyy" represents the name of the } \\
\text { tank. } \\
\text { The time scale of the horizontal time axis is } \\
\text { based on the SELECT TIME INTERVAL } \\
\text { chosen. }\end{array}$ & $\begin{array}{l}0.12 . \\
3 / 29 / 99\end{array}$ \\
\hline
\end{tabular}


HNF-4368, Rev. 0

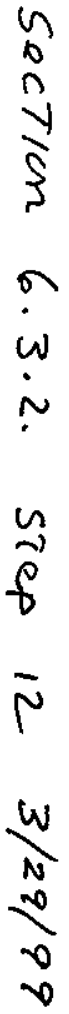
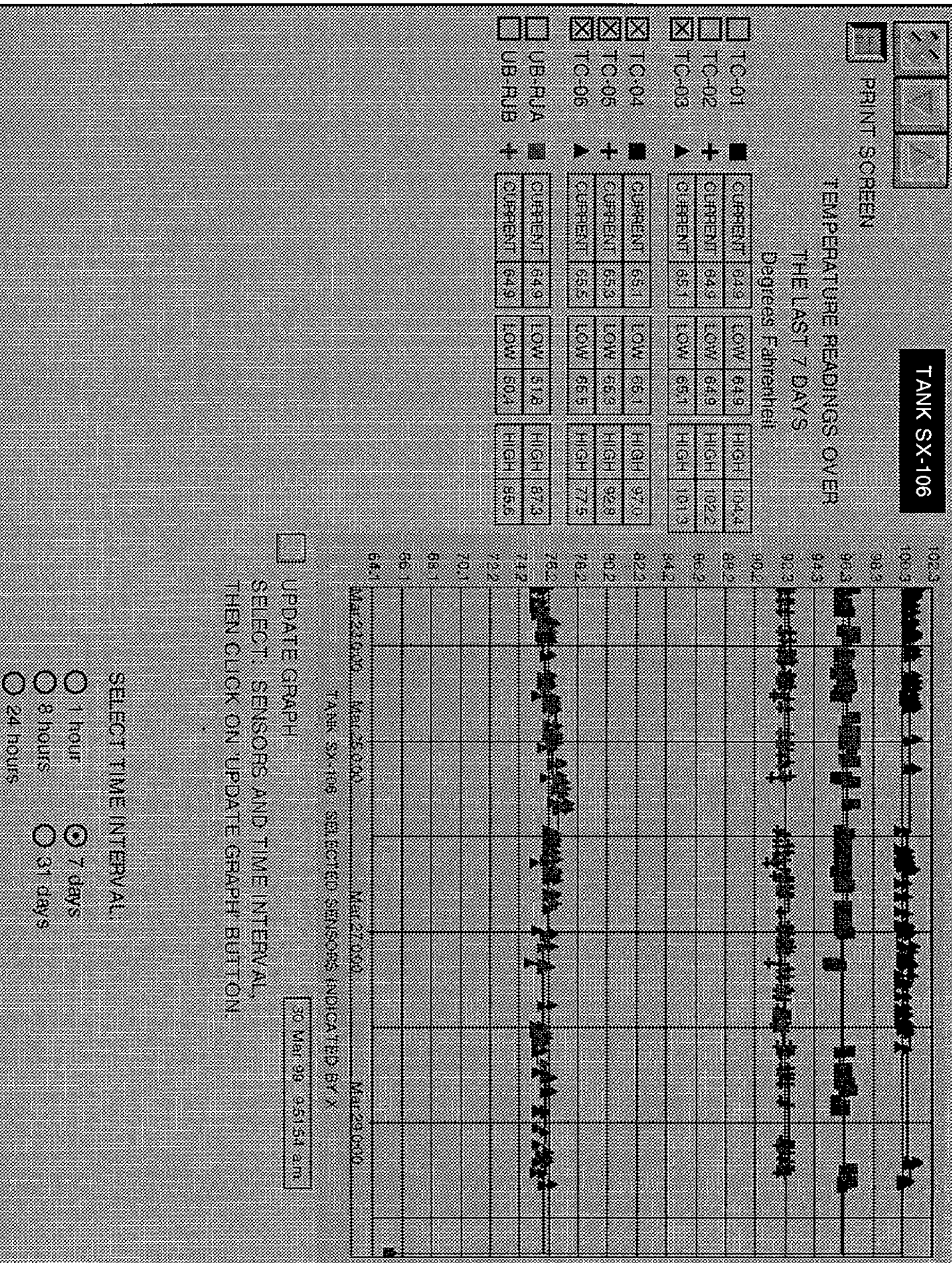
HNF-4368, Rev. 0

\begin{tabular}{|c|c|c|c|}
\hline Step & Perform & Expected Result & Initial \\
\hline & Oope & Atior of Sensot Check Box? ? ? & \\
\hline 3. & $\begin{array}{l}\text { Click on the box of any } \\
\text { sensor that contains an } \mathrm{X} \text {. }\end{array}$ & Verify that the $\mathrm{X}$ is removed from the box. & $\begin{array}{l}0.12 \\
3 / 29 / 99\end{array}$ \\
\hline 4. & $\begin{array}{l}\text { Click on the UPDATE } \\
\text { GRAPH button below the } \\
\text { graph. }\end{array}$ & $\begin{array}{l}\text { Verify the trend graph displays only lines for } \\
\text { the sensors that are checked. }\end{array}$ & $\begin{array}{l}0.02 \\
3 / 29 / 99\end{array}$ \\
\hline 5. & $\begin{array}{l}\text { Click on the box of any } \\
\text { sensor that does not } \\
\text { contain an X. }\end{array}$ & Verify that the $\mathrm{X}$ is displayed in the box. & $\begin{array}{l}0 . R \\
3 / 29 / 99\end{array}$ \\
\hline 6. & $\begin{array}{l}\text { Click on the UPDATE } \\
\text { GRAPH button below the } \\
\text { graph. }\end{array}$ & $\begin{array}{l}\text { Verify the trend graph displays only lines for } \\
\text { the sensors that are checked. }\end{array}$ & $\begin{array}{l}0.12 \\
3 / 29 / 99\end{array}$ \\
\hline & P: & 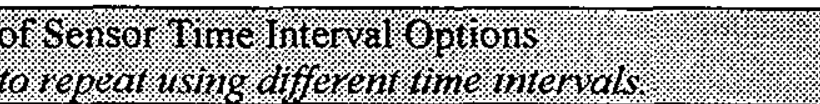 & \\
\hline 7. & $\begin{array}{l}\text { Click any "SELECT TIME } \\
\text { INTERVAL" option. }\end{array}$ & $\begin{array}{l}\text { Verify the following: } \\
\text { - A black dot appears in the circle of the time } \\
\text { interval selected. } \\
\text { - The Sensor Reading Description is } \\
\text { modified according to the SELECT TIME } \\
\text { INTERVAL chosen. (Note: Trend graph is } \\
\text { not updated automatically) }\end{array}$ & $\begin{array}{l}0.12 \\
3 / 29 / 99\end{array}$ \\
\hline 8. & $\begin{array}{l}\text { Click on the UPDATE } \\
\text { GRAPH button below the } \\
\text { graph. }\end{array}$ & $\begin{array}{l}\text { Verify the horizontal time scale of the trend } \\
\text { graph is reset to the SELECT TIME } \\
\text { INTERVAL chosen. }\end{array}$ & $3 / 29 / 99$ \\
\hline & 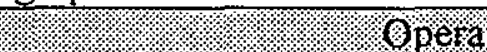 & on of Shink Windoy button: & \\
\hline 9. & $\begin{array}{l}\text { Click on the SHRINK } \\
\text { WINDOW button (an } \nabla \text { as } \\
\text { a symbol). }\end{array}$ & Verify that the workspace shrinks. & $\begin{array}{l}0 . R \\
3 / 2 q / 99\end{array}$ \\
\hline 10. & $\begin{array}{l}\text { Drag the workspace to the } \\
\text { upper right hand corner. }\end{array}$ & $\begin{array}{l}\text { Verify that the workspace stops at the edge of } \\
\text { the screen when dragged to the top or to the } \\
\text { right. }\end{array}$ & $\begin{array}{l}0.12 \\
3 / 29 / 99\end{array}$ \\
\hline & I: & 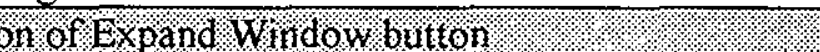 & \\
\hline 11. & $\begin{array}{l}\text { Click on the EXPAND } \\
\text { WINDOW button (an } 4 \\
\text { as a symbol). }\end{array}$ & Verify that the workspace enlarges. & $\begin{array}{l}0.12 \\
3 / 29 / 99\end{array}$ \\
\hline & ?: & $\begin{array}{l}\text { peration of Plint button } \\
\text { ble in a lelewindows' session: }\end{array}$ & \\
\hline 12. & $\begin{array}{l}\text { Click on the PRINT } \\
\text { SCREEN button. }\end{array}$ & $\begin{array}{l}\text { Verify that the User Selectable Trend } \\
\text { workspace prints. }\end{array}$ & $\begin{array}{l}0.2 \\
3 / 29 / 99\end{array}$ \\
\hline & (.) & atien of the HUDE button & \\
\hline 13. & $\begin{array}{l}\text { Click on the HIDE } \\
\text { WINDOW. }\end{array}$ & Verify that the workspace is hidden. & $\begin{array}{l}0 . R \\
3 / 2 q 199\end{array}$ \\
\hline
\end{tabular}


HNF-4368, Rev. 0

\subsection{EXTERNAL INTERFACES}

\subsubsection{Acromagrm}

The tests in this section require the use of an AcromagTM emulator. The test should be run on the development machine.

\subsubsection{Conversion of Acromag ${ }^{\mathrm{TM}}$ Temperature Output to Engineering Units}

\begin{tabular}{|c|c|c|c|}
\hline Step & Perform & $\begin{array}{r}\text { Expected Result } \\
\end{array}$ & Initial \\
\hline 1. & $\begin{array}{l}\text { From the tag list, choose } \\
\text { an Acromag }{ }^{\mathrm{TM}} \text { temperature } \\
\text { sensor at random. }\end{array}$ & $\begin{array}{l}\text { Write the sensor tag name here } \\
5 \angle 02-T L-\text { POOS }-0 Z\end{array}$ & $\begin{array}{l}0.12 . \\
3 / 22 / 99\end{array}$ \\
\hline 2. & $\begin{array}{l}\text { Use the Formula } \\
\text { expression and Raw Value } \\
\text { from the sensor details } \\
\text { button on the sensor's } \\
\text { trend to calculate the } \\
\text { current reading for the } \\
\text { sensor. }\end{array}$ & Write the value here 69.62 & $\begin{array}{l}0.12 \\
3 / 29 / 99\end{array}$ \\
\hline 3. & $\begin{array}{l}\text { Compare the Current } \\
\text { Reading with the reading } \\
\text { in Step } 2 .\end{array}$ & Verify that the readings are the same. & $\begin{array}{l}0.12 \\
3 / 27 / 99\end{array}$ \\
\hline 4. & $\begin{array}{l}\text { Examine the trend chart for } \\
\text { this sensor. }\end{array}$ & $\begin{array}{l}\text { Verify that the value graphed approximates the } \\
\text { temperature recorded in Step } 2 \text {. (Note: Three } \\
\text { or more points are needed for auto scaling.) }\end{array}$ & $\begin{array}{l}0.12 \\
3 / 29 / 99\end{array}$ \\
\hline
\end{tabular}

\subsubsection{Conversion of Acromag 4 to 20 ma Output to Engineering Units}

\begin{tabular}{|c|c|c|c|}
\hline Step & Perform & Expected Result & Initial \\
\hline 1. & $\begin{array}{l}\text { From the tag list, choose } \\
\text { an Acromag }{ }^{\mathrm{TM}} \text { non- } \\
\text { temperature sensor at } \\
\text { random, e.g., pressure, } \\
\text { flow, surface level, ... }\end{array}$ & $\begin{array}{l}\text { Write the sensor tag name here } \\
5102-F l-8006=025-7-1\end{array}$ & $\begin{array}{c}0.12 \\
3 / 22 / 98\end{array}$ \\
\hline 2. & $\begin{array}{l}\text { Use the Formula } \\
\text { expression and Raw Value } \\
\text { from the sensor details } \\
\text { button on the sensor's } \\
\text { trend to calculate the } \\
\text { current reading for the } \\
\text { sensor. }\end{array}$ & Write the value here, 0426 & $\begin{array}{l}0 . R \\
3 / 29 / 99\end{array}$ \\
\hline
\end{tabular}


HNF-4368, Rev. 0

\begin{tabular}{|l|l|l|c|}
\hline Step & \multicolumn{1}{|c|}{ Perform } & \multicolumn{1}{|c|}{ Expected Result } & Initial \\
\hline 3. & $\begin{array}{l}\text { Compare the Current } \\
\text { Reading with the reading } \\
\text { in Step 2. }\end{array}$ & Verify that the readings are the same. & $\begin{array}{l}0.2 . \\
3 / 2 q / 99\end{array}$ \\
\hline 4. & $\begin{array}{l}\text { Examine the trend chart for } \\
\text { this sensor. }\end{array}$ & $\begin{array}{l}\text { Verify that the value graphed matches the } \\
\text { temperature recorded in Step 2. (Note: Three } \\
\text { or more points are needed for auto scaling.) }\end{array}$ & $\begin{array}{c}0 . R \cdot \\
3 / 2 q / 9 q\end{array}$ \\
\hline
\end{tabular}

\subsubsection{Conversion of Acromag ${ }^{\mathrm{TM}}$ Digital Data to Discrete States}

The Acromag ${ }^{\mathrm{TM}}$ emulator does not directly support digital input for the Acromag ${ }^{\mathrm{TM}}$. A digital value of 0 may be simulated with a temperature value of $32.0 \mathrm{~F}$. A digital 1 is simulated with a temperature of $32.18 \mathrm{~F}$. Any other value will be an unknown state.

\begin{tabular}{|c|c|c|c|}
\hline Step & Perform & Expected Result & Initial \\
\hline 1. & $\begin{array}{l}\text { Using the tag list, choose } \\
\text { an enabled Acromag } \\
\text { digital sensor at random. }\end{array}$ & $\begin{array}{l}\text { Write the sensor tag name here } \\
5102-N S H-R 001-02 J-10-1\end{array}$ & $\begin{array}{l}0.12 \\
3 / 29 / 99\end{array}$ \\
\hline 2. & $\begin{array}{l}\text { Use the emulator to } \\
\text { simulate a value of digital } \\
0 \text { for this sensor. } \\
\text { After an appropriate delay } \\
\text { for the TMACS to poll the } \\
\text { emulator for this sensor. }\end{array}$ & Verify that the sensor is in alarm. & $\begin{array}{c}0 . R \\
5 / 29 / 99\end{array}$ \\
\hline 3. & $\begin{array}{l}\text { Use the emulator to } \\
\text { simulate a value of digital } \\
\text { I for this sensor. } \\
\text { After an appropriate delay } \\
\text { for the TMACS to poll the } \\
\text { emulator for this sensor. }\end{array}$ & Verify that the sensor is reset. & $\begin{array}{l}0.12 \\
3 / 29 / 89\end{array}$ \\
\hline 4. & Return to the main screen. & & $0.8 \% 3 / 24 / 99$ \\
\hline
\end{tabular}

\subsubsection{Enraf}

The tests in this section require the use of an Enraf emulator. The test should be run on the development machine.

\subsubsection{Conversion of Enraf ${ }^{(i)}$ CIU Output to Engineering Units}

\begin{tabular}{|l|l|l|l|}
\hline Step & \multicolumn{1}{|c|}{ Perform } & \multicolumn{1}{|c|}{ Expected Result } & Initial \\
\hline 1. & $\begin{array}{l}\text { From the tag list, choose } \\
\text { an Enraf } \\
\text { random. CIU sensor at }\end{array}$ & $\begin{array}{l}\text { Write the sensor tag name here } \\
S / 02-L /-R 002-0 /\end{array}$ & 0.2, \\
\cline { 2 - 3 } & & $3 / 2 q / 89$ \\
\hline
\end{tabular}


HNF-4368, Rev. 0

\begin{tabular}{|c|c|c|c|}
\hline Step & Perform & $\begin{array}{r}\text { Expected Result } \\
\end{array}$ & Initial \\
\hline 2. & $\begin{array}{l}\text { Use the Formula } \\
\text { expression and Raw Value } \\
\text { from the sensor details } \\
\text { button on the sensor's } \\
\text { trend to calculate the } \\
\text { current reading for the } \\
\text { sensor. }\end{array}$ & Write the value here 200.0 & $\begin{array}{l}0.12 \\
3 / 28 / 99 \\
3 / 30 / 99\end{array}$ \\
\hline 3. & $\begin{array}{l}\text { Compare the Current } \\
\text { Reading with the reading } \\
\text { in Step } 2 \text {. }\end{array}$ & Verify that the readings are the same. & $\begin{array}{l}0.12 \\
3 / 30 / 99 \\
3729799\end{array}$ \\
\hline 4. & $\begin{array}{l}\text { Examine the trend chart for } \\
\text { this sensor. }\end{array}$ & $\begin{array}{l}\text { Verify that the value graphed approximates the } \\
\text { temperature recorded in Step } 2 \text { (Note: Three } \\
\text { or more points are needed for anto scaling.) }\end{array}$ & $\begin{array}{l}0.21 \\
3 / 30 / 29\end{array}$ \\
\hline
\end{tabular}

\subsubsection{Westronics ${ }^{(i)}$}

The tests in this section require the use of a Westronics ${ }^{\infty}$ emulator. The test should be run on the development machine.

\subsubsection{Conversion of Westronics ${ }^{(2)}$ Temperature Output to Engineering Units}

\begin{tabular}{|c|c|c|c|}
\hline Step & Perform & Expected Result & Initial \\
\hline 1. & $\begin{array}{l}\text { From the tag list, choose a } \\
\text { Westronics }{ }^{2} \text { temperature } \\
\text { sensor at random. }\end{array}$ & $\begin{array}{l}\text { Write the sensor tag name here } \\
\text { AWLOA-IL- P006-037 }\end{array}$ & $\begin{array}{l}0.12 \\
3 / 30 / 99\end{array}$ \\
\hline 2. & $\begin{array}{l}\text { Use the Formula } \\
\text { expression and Raw Value } \\
\text { from the sensor details } \\
\text { button on the sensor's } \\
\text { trend to calculate the } \\
\text { current reading for the } \\
\text { sensor. }\end{array}$ & Write the value here 74.8 & $\begin{array}{l}0.12 \\
3 / 5199 \\
3 / 30 / 99\end{array}$ \\
\hline 3. & $\begin{array}{l}\text { Compare the Current } \\
\text { Reading with the reading } \\
\text { in Step } 2 .\end{array}$ & Verify that the readings are the same. & $\begin{array}{l}0.2 . \\
3 / 2 \% / 9\end{array}$ \\
\hline 4. & $\begin{array}{l}\text { Examine the trend chart for } \\
\text { this sensor. }\end{array}$ & $\begin{array}{l}\text { Verify that the value graphed approximates the } \\
\text { temperature recorded in Step } 2 \text {. (Note: Three } \\
\text { or more points are needed for auto scaling.) }\end{array}$ & $\begin{array}{l}0.2 . \\
3 / 30 / 29\end{array}$ \\
\hline
\end{tabular}

\subsubsection{Panalarm ${ }^{(i)}$}

The tests in this section require the use of a Panalarm ${ }^{\infty}$ emulator. The test should be run on the development machine. 
HNF-4368, Rev. 0

\subsubsection{Conversion of Panalarm ${ }^{\otimes}$ Output to Digital Data to Discrete States}

\begin{tabular}{|c|c|c|c|}
\hline Step & Perform & Expected Result & Initial \\
\hline 1. & $\begin{array}{l}\text { Using the tag list, choose a } \\
\text { Panalarm }{ }^{(2)} \text { sensor at } \\
\text { random. }\end{array}$ & $\begin{array}{l}\text { Write the sensor tag name here } \\
C 106-P_{S H}-1361 A\end{array}$ & $\begin{array}{c}0.12 \\
3 / 30 / 99\end{array}$ \\
\hline 2. & $\begin{array}{l}\text { Use the emulator to } \\
\text { simulate a value of digital } \\
1 \text { for this sensor. } \\
\text { After an appropriate delay } \\
\text { for the TMACS to poll the } \\
\text { emulator for this sensor. }\end{array}$ & Verify that the sensor is in alarm. & $\begin{array}{l}0.2 . \\
3 / 30 / 99\end{array}$ \\
\hline 3. & $\begin{array}{l}\text { Use the emulator to } \\
\text { simulate a value of digital } \\
0 \text { for this sensor. } \\
\text { After an appropriate delay } \\
\text { for the TMACS to poll the } \\
\text { emulator for this sensor. }\end{array}$ & Verify that the sensor is reset. & $\begin{array}{l}0 . R \\
3 / 30 / 99\end{array}$ \\
\hline 4. & Return to the main screen. & & $3 / 30 / 99$ \\
\hline
\end{tabular}

\subsubsection{SACS}

TMACS retrieves surface level data from SACS whenever TMACS starts and at 2000 every evening thereafter. The "last SACS reading" will be the last reading taken and marked good (the quality status was set to "G") before TMACS retrieves that data.

\begin{tabular}{|c|c|c|c|c|}
\hline Step & Perform & \multicolumn{2}{|c|}{ Expected Result } & Initial \\
\hline 1. & $\begin{array}{l}\text { Select a surface-level } \\
\text { sensor has been configured } \\
\text { for polling from SACS. }\end{array}$ & \multicolumn{2}{|c|}{$\begin{array}{l}\text { Record the sensor and tank names. } \\
\text { Sensor } \\
\text { Tank } \quad 5 / 02\end{array}$} & $\begin{array}{l}0 . R \\
3 / 30 / 99\end{array}$ \\
\hline 2. & $\begin{array}{l}\text { On the Hanford Tank Farm } \\
\text { Facilities workspace, click } \\
\text { on the tank icon for the } \\
\text { selected tank. } \\
\text { Click on the surface-level } \\
\text { icon. }\end{array}$ & \multicolumn{2}{|c|}{$\begin{array}{l}\text { Verify that the Sensor Trend workspace } \\
\text { appears. }\end{array}$} & $\begin{array}{c}O \cdot R \\
3 / 30 / 99\end{array}$ \\
\hline 3. & $\begin{array}{l}\text { Click on the detail button. } \\
\text { (Upper right-hand corner } \\
\text { of the Sensor Trend } \\
\text { workspace.) }\end{array}$ & \multicolumn{2}{|c|}{$\begin{array}{l}\text { Verify that the details about the surface-level } \\
\text { sensor appear. } \\
\text { Record the: } \\
\text { Current Reading } \\
\text { Last Good Reading } 2905.62 \\
\text { Sensor Type Name AuTOEN } 99: 23: 32 \\
\text { slvl_dttm }\end{array}$} & $\begin{array}{l}0.12 \\
3 / 30 / 99 \\
.000\end{array}$ \\
\hline 4. & $\begin{array}{l}\text { Close the Sensor Trend } \\
\text { workspace. }\end{array}$ & & & $\begin{array}{l}0.8 \\
3 / 30 / 99\end{array}$ \\
\hline
\end{tabular}


HNF-4368, Rev. 0

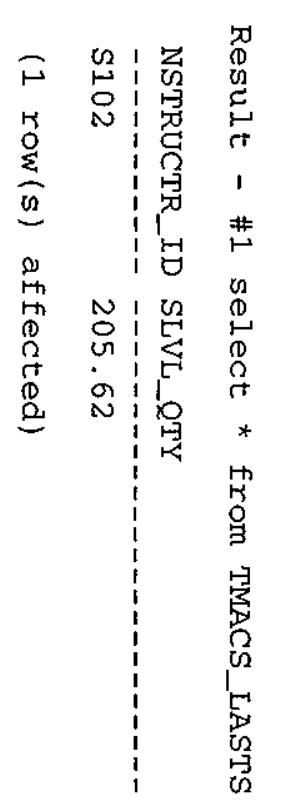

$\triangle \mid \begin{array}{ll}\text { C } \\ 1\end{array}$

r

18

落

可

in

空

19

18

1 可

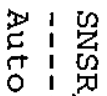

四:

奀囬

田

(1)

总

तु

.

o

D:

t

$\rightarrow$

619

6

I

남

.

$\infty$

落

Section 6.4 .5 step $5 \quad 3 / 30 / 99$ 

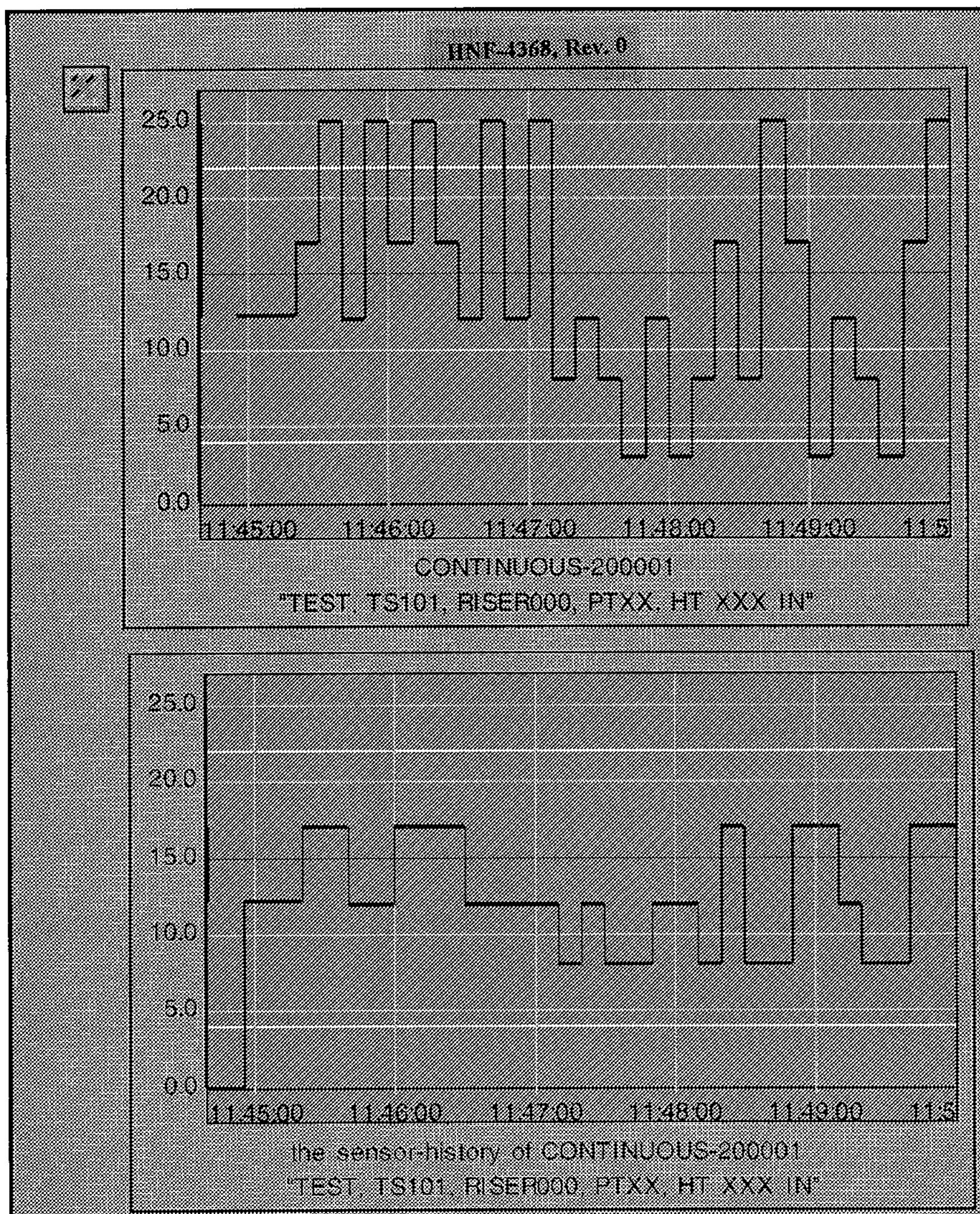

Secrion 6.5.1 S7epz $3 / 30 / 99$ 


\section{3/30/1999 WHC-SD-WM-TRP-105 Rev 11:0 Test Proc 1: Point Processing Page}

\section{CONTINUOUS-PT-PROC-TEST}

\begin{tabular}{|c|c|c|}
\hline Step Number & 30 & Verity \\
\hline Seq-Test Time Stamp & $30 \mathrm{Mar} 99 \quad 11: 50: 00 \mathrm{am}$. & \\
\hline Latest Reading & 12.2 & \\
\hline Last-Good-Reading-At & 30 Mar 99 11:50:00 a.m. & \\
\hline Sensor History & 12.2 & N.A. \\
\hline Quality Status & GOOD & N.A. \\
\hline Alarm State & NOPMAL & NA. \\
\hline Alarm Type & NO-ALARM & NA. \\
\hline Range Alarm Status & IN-RANGE & NA. \\
\hline ROC Alarm Status & ROC-IN-RANGE & N.A. \\
\hline Rate of Change & -4.8 & NA. \\
\hline Alarm Type Changed At & $30 \mathrm{Mar} 99$ 11:50:00 a.m. & N.A. \\
\hline Icon Blinking --? & true & NA. \\
\hline Display Color & GREEN & NA. \\
\hline Blink-Oti Color & GRAY & NA. \\
\hline Alarm-Aux Color & TRANSPARENT & NA. \\
\hline Background Color & MEOIUM-AQUAMARINE & N.A. \\
\hline Icon Blinking - ? & true & \\
\hline Display Color & GREEN & \\
\hline Blink-Off Color & GRAY & \\
\hline Occurred-At & $30 \mathrm{Mar} 99 \quad 11: 49: 50$ a.m. & N.A. \\
\hline Display Color & WHITE & NA. \\
\hline Alarm Number & 12 & N.A. \\
\hline & 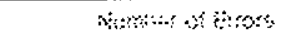 & 0 \\
\hline
\end{tabular}

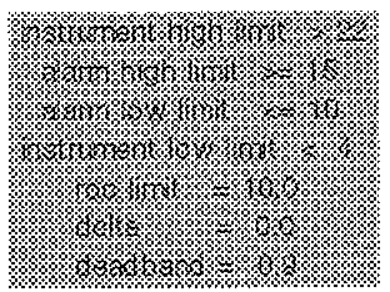

Test-Step

Time-Interval 10

For mili-steg test Click Boiow:

. . . . . . . . . $\begin{array}{ll}\text { Verify Results } & \\ \text { (Min time - 5) } & \odot \text { ON } \\ & \text { OFF }\end{array}$

Print Results is

(Min time-120)

O ON

O OFF

$\odot$ LAST
Hote: When in the "Step Mode", wait a minimum of the 'Tsst-Step Time-kntwa:" betwen sisps

(1) Step Mode O ON

For single-enty test

Enter: milli-amps 12.2

the ch10 of

ana-sta-ts-002

5125.0

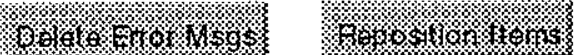
…… 
HNF-4368, Rev. 0

\begin{tabular}{|l|l|l|c|}
\hline Step & \multicolumn{1}{|c|}{ Perform } & \multicolumn{1}{|c|}{ Expected Result } & Initial \\
\hline 5. & $\begin{array}{l}\text { Obtain the last SACS } \\
\text { database reading for the } \\
\text { selected tank. Note: This } \\
\text { will be on the UDO server } \\
\text { most likely.) This may be } \\
\text { obtained from the system } \\
\text { administrator using the } \\
\text { following code: }\end{array}$ & $\begin{array}{l}\text { Verify that the values obtained in this step } \\
\text { match the values recorded in Step 3. }\end{array}$ & 0.2. \\
$\begin{array}{l}\text { lp_LastSLVLReading } \\
\text { '[Tank Name]' } \\
\text { select* } \\
\text { from } \\
\text { TMACS_LASTSLVLREA } \\
\text { DING }\end{array}$ & $3 / 29 t$ \\
\hline
\end{tabular}

\subsection{POINT PROCESSING}

\subsubsection{Continuous Sensor (Non Rate of Change) Automated Functional Test}

This procedure automatically tests the state changes for a continuous sensor.

\begin{tabular}{|c|c|c|c|}
\hline Step & Perform & Expected Result & Initial \\
\hline 1. & $\begin{array}{l}\text { On the POINT } \\
\text { PROCESSING } \\
\text { FUNCTIONAL TEST } \\
\text { workspace click on the } \\
\text { Point Processing for } \\
\text { Continuous Point - All } \\
\text { Function excepts Rate of } \\
\text { Change button }\end{array}$ & $\begin{array}{l}\text { Verify the CONTINUOUS FUNCTIONAL } \\
\text { TEST (Except ROC) workspace appears. }\end{array}$ & $\begin{array}{l}\text { OR } \\
3 / 30 / 99\end{array}$ \\
\hline 2. & $\begin{array}{l}\text { On the CONTNUOUS } \\
\text { FUNCTIONAL TEST } \\
\text { (Except ROC) workspace: } \\
\text { - Set the Step Mode to } \\
\text { "Off." } \\
\text { - Set Print Results to } \\
\text { "Last" } \\
\text { Activate the "Run Point } \\
\text { Processing" button. }\end{array}$ & Verify that the process continues to completion & $\begin{array}{l}0 . R \\
3 / 30 / 99\end{array}$ \\
\hline 3. & Examine the results & Verify no errors are reported. & $0.2 / 3019$ \\
\hline 4. & Print the final workspace. & Keep printout for project files. & $\frac{0.02}{3 / 30 / 99}$ \\
\hline
\end{tabular}


HNF-4368, Rev. 0

3/30/1999 WHC-SD-WM-TRP-105 Rev 11.0 Test Proc 1: Point Processing Page

\section{RATE-OF-CHANGE-PROC-TEST}

\begin{tabular}{|c|c|c|}
\hline Step Number & 44 & Verify \\
\hline Seq-Test Time Stamp & $30 \mathrm{M}$ ar 99 12:03:53 p.m. & \\
\hline Latest Reading & 12.2 & \\
\hline Last-Good-Reading-At & 30 Mar 99 12:03:53 p.m. & \\
\hline Sensor History & 12.2 & N.A. \\
\hline Quality Status & GOOD & NA. \\
\hline Alarm State & NOPMAL & N.A. \\
\hline Alarm Type & NO-ALARM & NA. \\
\hline Range Alarm Status & IN-RANGE & NA. \\
\hline Roc Alarm Status & ROC-IN-PANGE & NA. \\
\hline Rate of Change & 1.2 & NA. \\
\hline Alarm Type Changed At & $30 \mathrm{Mar} 99$ 12:03:43 p.m. & NA. \\
\hline Icon Blinking --? & true & N.A. \\
\hline Display Color & GREEN & NA. \\
\hline Blink-Off Color & GRAY & N.A. \\
\hline Alarm-Aux Color & TRANSPARENT & NA. \\
\hline Background Color & MEDIUM-AQUAMARINE & N.A. \\
\hline Icon Blinking --? & true & \\
\hline Display Color & GREEN & \\
\hline 8link-Off Color & GRAY & \\
\hline & $\cdot$ & \\
\hline Occurred-At & 30 Mar 99 12:03:33 p.m. & NA. \\
\hline Display Color & GFEEN & N.A. \\
\hline A larm Number & 10 & NA. \\
\hline & 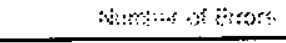 & 0 \\
\hline
\end{tabular}

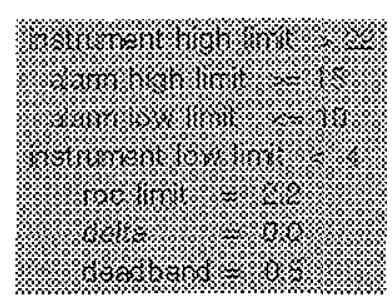

Verify Results

(Min time - 5)

$\mathrm{O} O \mathrm{~N}$

$\odot$ OFF

Print Results is

(Min time -120)
Test-Step

Time-Interval 10

For malti-siep test Click Bsiow:

.
Note: When in the "Step wode", wait a minimum of the "Test-Btes Time-hntwa: boween steps

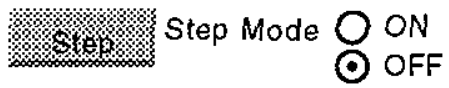

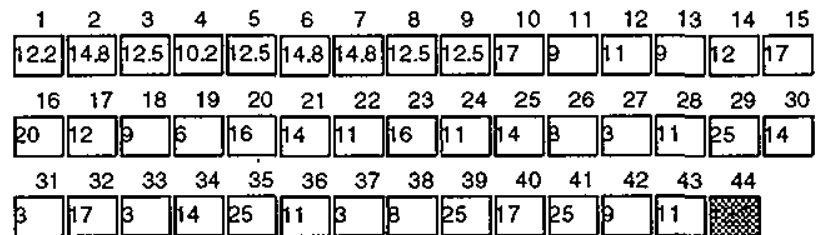

For single-entry test Enter: milli-amps 12.2

the ch10 of ana-sta-ts-002 5125.0

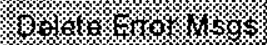

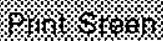

\%
...

1. 
: n.
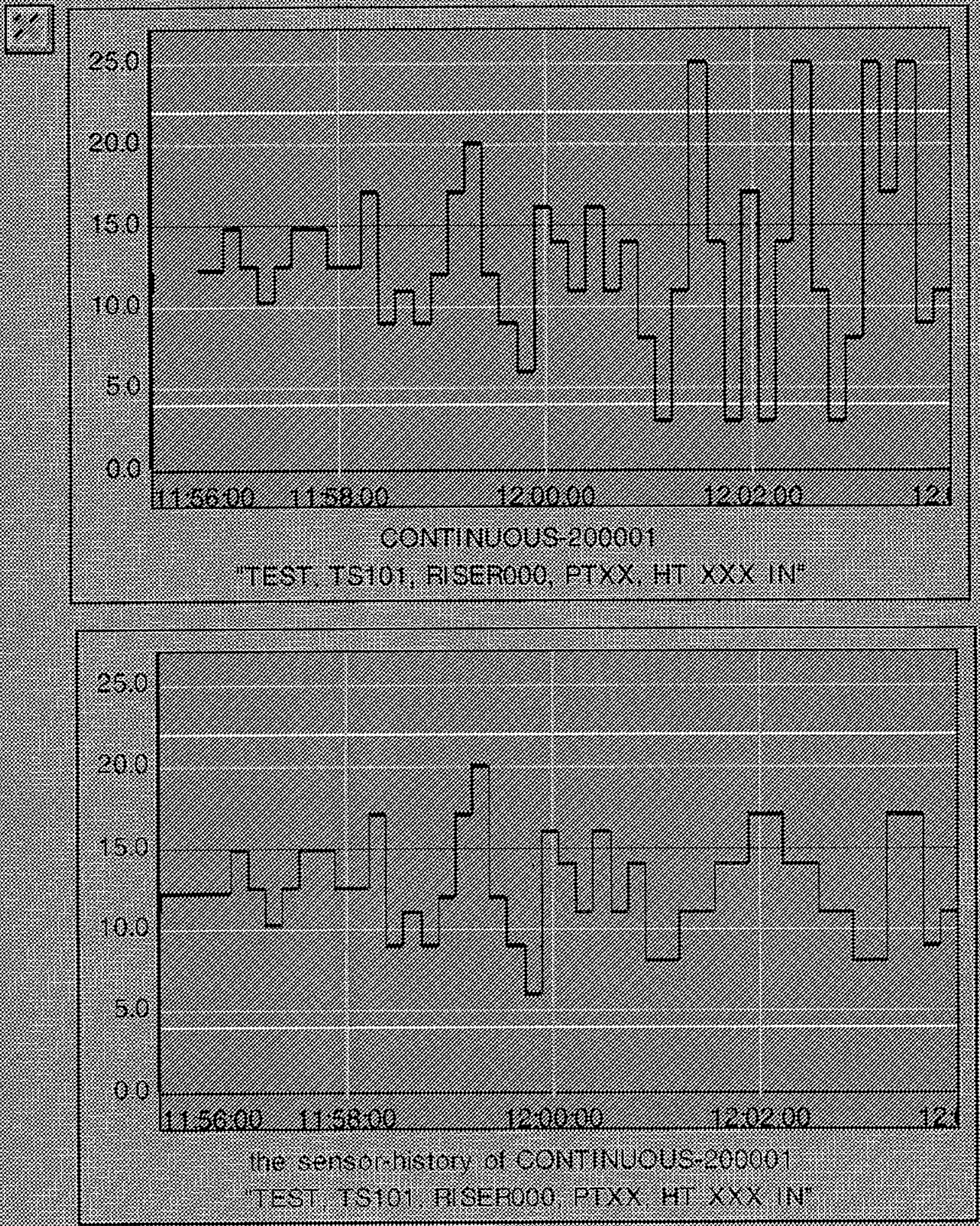

Section 6.5.2 srep 4 $3 / 30 / 99$ 
HNF-4368, Rev. 0

\subsubsection{Continuous Sensor (Rate of Change) Automated Functional Test}

\begin{tabular}{|c|c|c|c|}
\hline Step & Perform & Expected Result & Initial \\
\hline 1. & $\begin{array}{l}\text { On the POINT } \\
\text { PROCESSING } \\
\text { FUNCTIONAL TEST } \\
\text { workspace click on the } \\
\text { Point Processing for } \\
\text { Continuous Point -Rate } \\
\text { of Change button. }\end{array}$ & $\begin{array}{l}\text { Verify the CONTINUOUS FUNCTIONAL } \\
\text { TEST (With ROC) workspace appears. }\end{array}$ & $\begin{array}{c}O \cdot R \\
3 / 30 / 99\end{array}$ \\
\hline 2. & $\begin{array}{l}\text { On the ROC } \\
\text { FUNCTIONAL TEST } \\
\text { workspace: } \\
\text { Set the Step Mode to } \\
\text { "Off." } \\
\text { Set Print Results to "Last" } \\
\text { Activate the "Run Point } \\
\text { Processing" button. }\end{array}$ & Verify that the process continues to completion. & $\begin{array}{c}O . R \\
3 / 30 / 99\end{array}$ \\
\hline 3. & Examine the workspace. & Verify no errors are reported. & $3 / 30 / 99$ \\
\hline 4. & Print the final workspace. & Keep printout for project files. & $3 \longdiv { 3 0 / 8 9 }$ \\
\hline
\end{tabular}

\subsubsection{Discrete Sensor Automated Functional Test}

This procedure automatically tests the rate of change process.

\begin{tabular}{|c|c|c|c|}
\hline Step & Perform & Expected Result & Initial \\
\hline 1. & $\begin{array}{l}\text { On the POINT } \\
\text { PROCESSING } \\
\text { FUNCTIONAL TEST } \\
\text { workspace click on the } \\
\text { Point Processing for } \\
\text { Discrete Points - All } \\
\text { Functions button }\end{array}$ & $\begin{array}{l}\text { Verify the DISCRETE FUNCTIONAL TEST } \\
\text { workspace appears. }\end{array}$ & $\begin{array}{c}\text { O.R. } \\
3 / 30 / 99\end{array}$ \\
\hline 2. & $\begin{array}{l}\text { On the Discrete Functional } \\
\text { Test workspace: } \\
\text { Set the Step Mode to } \\
\text { "Off." } \\
\text { Set Print Results to "Last" } \\
\text { Activate the "Run Point } \\
\text { Processing " button. }\end{array}$ & Verify that the process continues to completion. & $\begin{array}{c}0 \cdot R \\
3 / 30 / 99\end{array}$ \\
\hline 3. & Examine the workspace. & Verify no errors are reported. & $5 / 30 / 99$ \\
\hline 4. & Print the final workspace. & Keep printout for project files. & $0.8 \% 0 / 99$ \\
\hline
\end{tabular}

Prior to running this test the administrator should do the following: 
HNF-4368, Rev. 0

3/30/1999 WHC-SD-WM-TRP-105 Rev 11.0 Test Proc 1: Point Processing Page

\section{DISCRETE-PT-PROC-TEST}

\begin{tabular}{|c|c|c|}
\hline Step Number & 10 & Verity \\
\hline Seq-Test Time Stamp & $30 \mathrm{Mar} 99 \quad 11: 37: 12 \mathrm{am}$. & \\
\hline Latest Reading & 0 & \\
\hline Last-Good-Reading-At & $30 \mathrm{Mar} 99 \quad$ 12:15:22 p.m. & \\
\hline Sensor History & 0 & N.A. \\
\hline Quality Status & GOOD & N.A. \\
\hline Alarm State & NORMAL & N.A. \\
\hline Annotation & OPEN & NA. \\
\hline Alarm State Changed At & $30 \mathrm{Mar} 99 \quad$ 12:15:22 pm. & NA. \\
\hline Icon Blinking --? & true & N.A. \\
\hline Display Color & GREEN & NA. \\
\hline Blink-Off Color & GRAY & NA. \\
\hline Alarm-Aux Color & TRANSPARENT & NA. \\
\hline Background Color & MEDIUM-AQUAMAFINE & N.A. \\
\hline Icon Blinking --? & true & \\
\hline Display Color & GREEN & \\
\hline Blink-Off Color & GRAY & \\
\hline Occurred-At & 30 Mar 99 12:15:02 p.rn. & NA. \\
\hline Display Color & WHITE & NA. \\
\hline \multirow[t]{2}{*}{ Alarm Number } & 3 & N.A. \\
\hline & 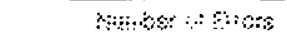 & 0 \\
\hline
\end{tabular}

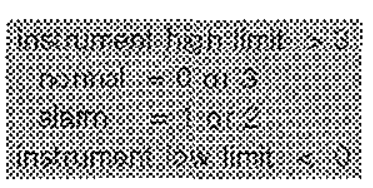

Verify Results

(Min time - 5)

ON

OFF

Print Results is

(Min time -120)

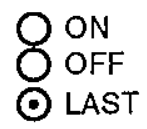

Test-Step

Time-Interval 10

For routi-step test Click Bolow:

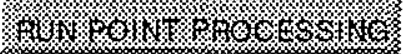

$$
\begin{aligned}
& \begin{array}{lllll}
1 & 2 & 3 & 4 & 5
\end{array} \\
& \begin{array}{|l|l|l|l|l|}
\hline 0 & 3 & 2 & 3 & 4 \\
\hline
\end{array} \\
& \begin{array}{lllll}
6 & 7 & 8 & 9 & 10
\end{array} \\
& \begin{array}{|l|l|l|l|l|}
\hline 2 & 1 & 4 & -1 & \text { 細 } \\
\hline
\end{array}
\end{aligned}
$$

For single-step test

Enter: dip-switch setting 0

1.

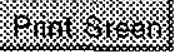

1.6. wait a rininum of the "isst-step Time-intevai" betwenn steps
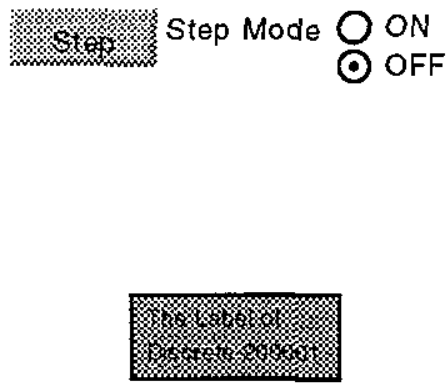

1...
Note: When in the "Step Mode".

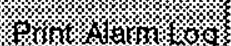



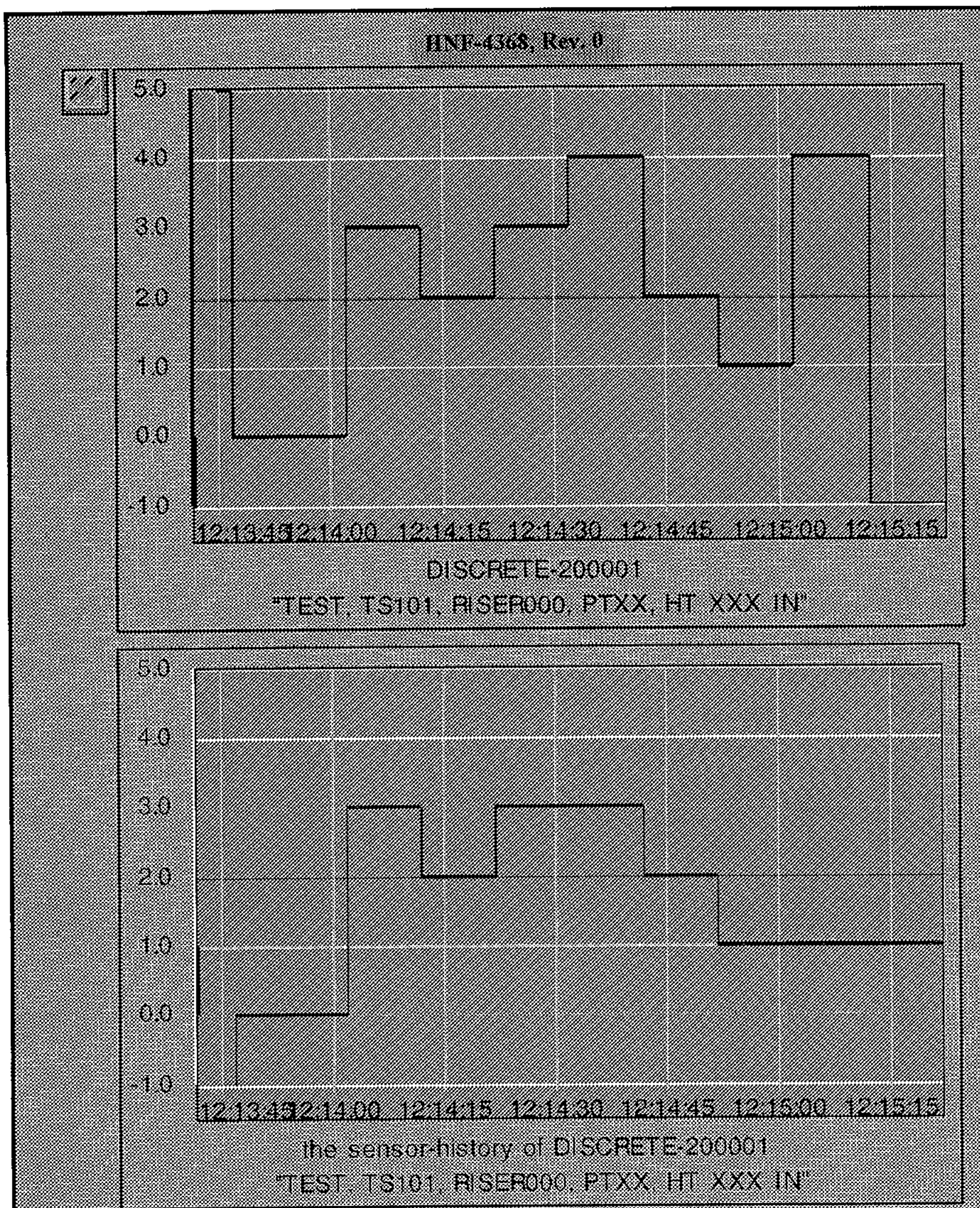

Soction 6.5 .3 siep $4 \quad 3 / 30 / 99$ 
1. Acknowledge all alarms so Current Alarm count goes to zero. Note: if this is not done, then note the number of current alarms.

2. Verify the following workspaces are visible:

- DISCRETE FUNCTIONAL TEST

- MOST RECENT ALARM

- control-PANEL

- CURRENT ALARM

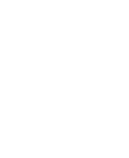

\begin{tabular}{|c|c|c|c|c|}
\hline Step & Perform & $\begin{array}{r}\text { Expected Result } \\
\end{array}$ & Initial & \\
\hline 1. & $\begin{array}{l}\text { On the Discrete Functional } \\
\text { Test Workspace } \\
\text { Set the Step Mode in ON. } \\
\text { Activate the RUN POINT } \\
\text { PROCESSING button. } \\
\text { Examine the Current } \\
\text { Alarm box. }\end{array}$ & $\begin{array}{l}\text { Note the number of current alarms } \\
300\end{array}$ & nod & nks \\
\hline 2. & $\begin{array}{l}\text { Enter } 4 \text { in Dip-switch type- } \\
\text { in box on the Discrete } \\
\text { Functional Test } \\
\text { Workspace. }\end{array}$ & $\begin{array}{l}\text { Verify the following: } \\
\text { - A white message for the discrete alarm is } \\
\text { generated in the MOST RECENT ALARM } \\
\text { workspace. } \\
\text { - No Current Alarms = } 1 \text { more than Step } 1 \text {. }\end{array}$ & $\begin{array}{l}(301) \\
n Q 7)\end{array}$ & $\begin{array}{l}(301) \\
\text { noll }\end{array}$ \\
\hline 3 . & $\begin{array}{l}\text { Enter }-1 \text { in Dip-switch } \\
\text { type-in box on the } \\
\text { Discrete Functional Test } \\
\text { Workspace. }\end{array}$ & No Change from previous & & nets \\
\hline 4. & $\begin{array}{l}\text { Enter } \underline{2} \text { in Dip-switch type- } \\
\text { in box on the Discrete } \\
\text { Functional Test } \\
\text { Workspace. }\end{array}$ & $\begin{array}{l}\text { Verify the following: } \\
\text { - A discrete alarm message is generated in } \\
\text { the MOST RECENT ALARM workspace. } \\
\text { - No. Current Alarms }=2 \text { more than in Step } 1 \\
\text { on the following workspaces: } \\
\text { 1. CURRENT ALARMS } \\
\text { 2. CONTROL PANEL } \\
\text { 3. MOST RECENT ALARM }\end{array}$ & ness & moss \\
\hline 5. & $\begin{array}{l}\text { On the Most Recent Alarm } \\
\text { workspace activate the } \\
\text { GOTO button }\end{array}$ & $\begin{array}{l}\text { Verify the following: } \\
\text { - TANK TEST-201 STATUS workspace is } \\
\text { brought to the top of the screen. } \\
\text { - The sensor is in alarm. }\end{array}$ & $\begin{array}{l}3 \div \\
350\end{array}$ & nos \\
\hline 6. & $\begin{array}{l}\text { Enter } 0 \text { in Dip-switch type- } \\
\text { in box on the Discrete } \\
\text { Functional Test } \\
\text { Workspace. }\end{array}$ & $\begin{array}{l}\text { Verify the following: } \\
\text { - Discrete alarm message is reset. } \\
\text { - No. Current Alarms }=2 \text { more than Step } 1 \\
\text { on the following workspaces: } \\
\text { 1. CURRENT ALARMS }\end{array}$ & $m 5 s$ & \\
\hline
\end{tabular}


HNF-4368, Rev. 0

\begin{tabular}{|c|c|c|c|}
\hline Step & Perform & Expected Result & Initial \\
\hline & & $\begin{array}{l}\text { 2. CONTROL PANEL } \\
\text { 3. MOST RECENT ALARM }\end{array}$ & nise \\
\hline 7. & $\begin{array}{l}\text { Acknowledge alarm } \\
\text { message in MOST } \\
\text { RECENT ALARM } \\
\text { Window by clicking on it. }\end{array}$ & 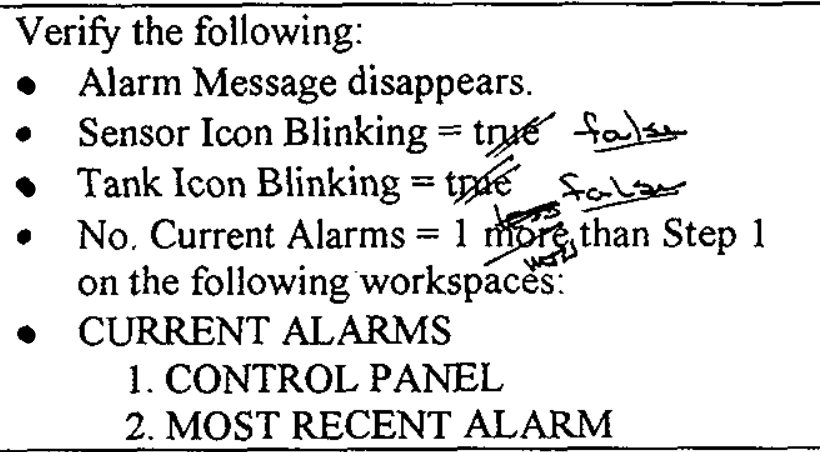 & $\begin{array}{l}\text { Soe } 5 \\
A=5\end{array}$ \\
\hline 8. & $\begin{array}{l}\text { Acknowledge the White } \\
\text { alarm message }\end{array}$ & $\begin{array}{l}\text { Verify the following: } \\
\text { - Alarm Message disappears } \\
\text { - Sensor Icon Blinking = false } \\
\text { - Tank Icon Blinking = false } \\
\text { - No. Current Alarms = the same as in Step } 1 \\
\text { on the following workspaces: } \\
\text { 1. CURRENT ALARMS } \\
\text { 2. CONTROL PANEL } \\
\text { 3. MOST RECENT ALARM }\end{array}$ & \\
\hline
\end{tabular}

\subsubsection{Operation of Sensor Delta Band and Alarm Deadband}

This test will verify that the operation of the sensor band and the alarm deadband for continuous sensors.

Prior to running this test the administrator should do the following:

1. Verify that the Rate of Change processing is disabled for Sensor Continuous-200001.

2. Verify that the parameters for Sensor Continuous-200001 are set to match the parameters in Table 1. (See Prerequisites)

3. Verify that the following workspaces are visible.

- continuOUS fUNCTIONAL TEST

- MOST RECENT ALARM 
HNF-4368, Rev. 0

\begin{tabular}{|c|c|c|c|}
\hline Step & Action & Verify the Alarm Condition is: & Initial \\
\hline 1. & $\begin{array}{l}\text { On the Continuous Functional Test } \\
\text { Workspace } \\
\text { - Set the Step Mode in ON. } \\
\text { Activate the RUN POINT } \\
\text { PROCESSING button. } \\
\text { Enter } 14.8 \text { in milli-amps type-in } \\
\text { box }\end{array}$ & NORMAL & nos? \\
\hline 2. & Enter 14.4 in milli-amps type-in box & NORMAL & $4(5)$ \\
\hline 3. & Enter 14.3 in milli-amps type-in box & NORMAL & $14 \pi 28$ \\
\hline 4. & Enter 14.8 in milli-amps type-in box & NORMAL & noth \\
\hline 5. & Enter $\mathbf{1 5 . 2}$ in milli-amps type-in box & ALARM-HIGH & noss \\
\hline 6. & Enter $\mathbf{1 5 . 3}$ in milli-amps type-in box & ALARM-HIGH & must \\
\hline 7. & Enter 14.9 in milli-amps type-in box & ALARM-HIGH & $\operatorname{lng} 2$ \\
\hline 8. & Enter $\mathbf{1 4 . 6}$ in milli-amps type-in box & ALARM-HIGH & $\operatorname{mos}$ \\
\hline 9. & Enter 14.0 in milli-amps type-in box & NORMAL & nod \\
\hline 10. & Enter 13.5 in milli-amps type-in box & NORMAL & $k+t$ \\
\hline 11. & Enter 15.0 in milli-amps type-in box & ALARM-HIGH & hess \\
\hline 12. & Enter 10.6 in milli-amps type-in box & NORMAL & ms \\
\hline 13. & Enter 15.0 in milli-amps type-in box & ALARM-HIGH & nos \\
\hline 14. & Enter 9.9 in milli-amps type-in box & ALARM-LOW & nat \\
\hline 15. & Enter $\mathbf{1 0 . 2}$ in milli-amps type-in box & ALARM-LOW & nots \\
\hline 16. & Enter $\mathbf{1 0 . 5}$ in milli-amps type-in box & ALARM-LOW & जबतर \\
\hline 17. & Enter 11.0 in milli-amps type-in box & NORMAL & $\operatorname{mos}$ \\
\hline 18. & Enter 11.5 in milli-amps type-in box & NORMAL & 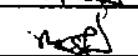 \\
\hline
\end{tabular}

\subsubsection{Operation of Enable/Disable Procedures}

Verify that the following workspaces are visible.

- Continuous Function Test

- Tank Test-201

- Enable/Disable Point Processing

- Most Recent Alarm

- Discrete-200001 Sensor 


\begin{tabular}{|c|c|c|c|c|}
\hline Step & Perform & Expected Result & Initial & \multirow{5}{*}{$\begin{array}{l}\text { Olarm } \\
\text { Connt } \\
\text { is } \\
300 \\
\text { ot start } \\
\text { of tert }\end{array}$} \\
\hline 1. & $\begin{array}{l}\text { On the Continuous } \\
\text { Functional Test } \\
\text { workspace enter } 17 \text { in the } \\
\text { "milliamps" type-in box. }\end{array}$ & $\begin{array}{l}\text { Verify the following: } \\
\text { - Alarm message is displayed } \\
\text { - Number of Current Alarms increases by } \\
\text { one. }\end{array}$ & & \\
\hline 2. & $\begin{array}{l}\text { Position the enable/disable } \\
\text { pointer over the } \\
\text { Continuous-200001 sensor } \\
\text { and activate the button } \\
\text { "Toggle Point". }\end{array}$ & $\begin{array}{l}\text { Verify that the following conditions occur: } \\
\text { - Blue message is displayed: "The POINT- } \\
\text { PROCESSING of CONTINUOUS-200001 } \\
\text { has been DISABLED", with the timestamp } \\
\text { of this change. } \\
\text { - Previous alarm message disappears and the } \\
\text { total "Number of Current Alarms" remains } \\
\text { the same. } \\
\text { - Point processing attribute of sensor changes } \\
\text { to false. } \\
\text { - Sensor turns gray. } \\
\text { Tank color is the same as the DISCRETE- } \\
200001 \text { sensor color. }\end{array}$ & nus & \\
\hline 3. & $\begin{array}{l}\text { With the enable/disable } \\
\text { pointer still over the } \\
\text { Continuous-200001 sensor, } \\
\text { activate the button "Toggle } \\
\text { Point". }\end{array}$ & $\begin{array}{l}\text { Verify that the following conditions occur: } \\
\text { - Blue message is displayed: "The POINT- } \\
\text { PROCESSING of CONTINUOUS-200001 } \\
\text { has been ENABLED", with the timestamp } \\
\text { of this change. } \\
\text { - "Number of Current Alarms" remains the } \\
\text { same. } \\
\text { - Point processing attribute of sensor changes } \\
\text { to true. } \\
\text { - Sensor turns white. } \\
\text { - Tank color white or the color of the } \\
\text { DISCRETE-200001 sensor alarm color (if } \\
\text { not green). }\end{array}$ & $\ln 58$ & \\
\hline 4. & $\begin{array}{l}\text { Select a tank on the HTFF } \\
\text { workspace that has a good } \\
\text { mix of sensor types. } \\
\text { Enter the chosen tank in } \\
\text { the type-in box labeled } \\
\text { "Tank on which to enable / } \\
\text { disable point processing". } \\
\text { Without moving the } \\
\text { enable/disable pointer } \\
\text { activate the button "Toggle } \\
\text { Point". }\end{array}$ & $\begin{array}{l}\text { Verify that the following conditions occur: } \\
\text { - Blue message is displayed: "The POINT- } \\
\text { PROCESSING of [the nearest sensor to the } \\
\text { pointer-frequently the level sensor] has } \\
\text { been DISABLED", with the timestamp of } \\
\text { this change; } \\
\text { - Point processing attribute of sensor changes } \\
\text { to false; } \\
\text { - Sensor turns gray; } \\
\text { - Tank color is the same as the highest } \\
\text { priority sensor alarm }\end{array}$ & & \\
\hline
\end{tabular}


HNF-4368, Rev. 0

\begin{tabular}{|c|c|c|c|}
\hline Step & Perform & Expected Result & Initial \\
\hline 5 & $\begin{array}{l}\text { Activate the button } \\
\text { "Toggle Point" again. }\end{array}$ & $\begin{array}{l}\text { Verify that the following conditions occur: } \\
\text { - Blue message is displayed: "The POINT- } \\
\text { PROCESSING of [the nearest sensor to the } \\
\text { pointer] has been ENABLED", with the } \\
\text { timestamp of this change; } \\
\text { - Point processing attribute of sensor changes } \\
\text { to true; } \\
\text { - Sensor turns white; } \\
\text { - Tank icon turns white or the color of the } \\
\text { highest priority sensor alarm. }\end{array}$ & \\
\hline 6. & $\begin{array}{l}\text { Activate the button "All } \\
\text { points in tank off". }\end{array}$ & $\begin{array}{l}\text { Verify that the following conditions occur: } \\
\text { - Blue messages are displayed: "The POINT- } \\
\text { PROCESSING of [each sensor monitoring } \\
\text { this tank] has been DISABLED" with the } \\
\text { time of this change; } \\
\text { - Point processing attribute of sensors } \\
\text { changes to false; } \\
\text { - Sensors turn gray; } \\
\text { - All sensor alarms associated with this tank } \\
\text { are cleared; } \\
\text { - Tank color turns gray. }\end{array}$ & \\
\hline 7. & $\begin{array}{l}\text { Activate the button "All } \\
\text { points in tank on". }\end{array}$ & $\begin{array}{l}\text { Verify that the following conditions occur: } \\
\text { - Blue messages are displayed: "The POINT- } \\
\text { PROCESSING of [each sensor monitoring } \\
\text { this tank] has been ENABLED" with the } \\
\text { time of this change; } \\
\text { - Point processing attribute of sensors } \\
\text { changes to true; } \\
\text { - Sensors turn white; } \\
\text { - Tank turns white. }\end{array}$ & \\
\hline 8. & $\begin{array}{l}\text { On the Current Alarms } \\
\text { workspace click on the } \\
\text { Clear All Blue Messages } \\
\text { button. }\end{array}$ & $\begin{array}{l}\text { Verify the Blue Messages disappear from the } \\
\text { Current Alarms list. }\end{array}$ & $m=58$ \\
\hline 9 & $\begin{array}{l}\text { Hide the following } \\
\text { workspaces: } \\
\text { - Tank (selected in test) } \\
\text { - Enable/Disable Point } \\
\text { Processing } \\
\text { - Discrete-200001 } \\
\text { Sensor }\end{array}$ & Verify the workspaces are hidden. & \\
\hline
\end{tabular}




\section{HNF-4368, Rev. 0}

\subsubsection{Miscellaneous Alarm Tests}

The purpose of this test is to verify the relationships between the sensor icons, tank icon, Current Alarms Workspace and the annuciator.

Prior to running this test the administrator should do the following:

1. Make sure the following workspaces visible.

- Functional Test Selection Workspace (Only to see the TANK-ICON-TEST-201 icon)

- Continuous Functional Test Workspace

- The Discrete Functional Test Workspace.

- The TANK TEST-201 workspace.

- The MOST RECENT ALARM workspace

- Discrete-200001 Sensor

2. Make sure the enunciator is enabled. This is done by the following:

- $\quad$ Bring up the TMACS-LIB workspace and its subworkspace labeled STARTUP-WS and Activate the "TOGGLE-AUDIBLE" button and verify that the display of the alarm-audible symbol changes from false to true.

\begin{tabular}{|c|c|c|c|}
\hline Step & Perform & Expected Result & Initial \\
\hline 1. & $\begin{array}{l}\text { Enter } 1 \text { in Dip-switch type-in box } \\
\text { on the Discrete Functional Test } \\
\text { Workspace. } \\
\text { Enter a } 11 \text { in Milli-amp type-in } \\
\text { box on the Continuous } \\
\text { Functional Test Workspace } \\
\text { Note: May have to click on the } \\
\text { Run Point Process button on both } \\
\text { the Discrete and Continuous } \\
\text { Function Test Workspaces. }\end{array}$ & $\begin{array}{l}\text { Most Recent Alarm } \\
\text { - Message Status = Closing } \\
\text { - } \quad \text { Display Color }=\text { Yellow } \\
\text { - Text Color = Red } \\
\text { Discrete Functional Test Workspace } \\
\text { Discrete - 2001 } \\
\text { - Discrete Icon Blinking = true } \\
\text { - Display Color = YELLOW } \\
\text { - Blink-off Color = GRAY } \\
\text { - Alarm Aux Color = YELLOW } \\
\text { Tank Icon Test-201 } \\
\text { - Icon Blinking = true } \\
\text { - Display Color = YELLOW }\end{array}$ & 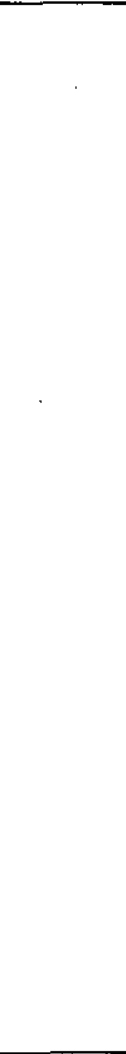 \\
\hline
\end{tabular}


HNF-4368, Rev. 0

\begin{tabular}{|c|c|c|c|}
\hline Step & Perform & Expected Result & Initial \\
\hline & 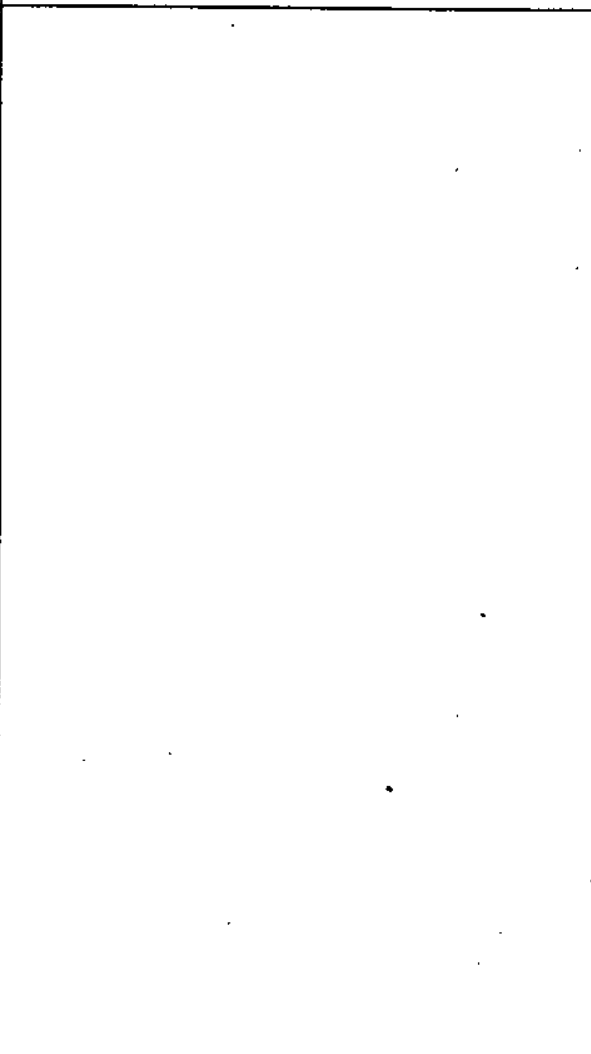 & $\begin{array}{l}\text { - } \quad \text { Blink-off Color = GRAY } \\
\text { Latest Alarm Message } \\
\text { - Display Color = Yellow } \\
\text { Continuous Functional Test Workspace } \\
\text { Continuous -2001 } \\
\text { - Cont. Icon Blinking = false } \\
\text { - } \quad \text { Display Color = GREEN } \\
\text { - Blink-off Color = (N/A - skip) } \\
\text { - Alarm Aux Color = TRANSPARENT } \\
\text { Tank Icon Test-201 } \\
\text { - Icon Blinking = true } \\
\text { - Display Color = YELLOW } \\
\text { - Blink-off Color = GRAY } \\
\text { Latest Alarm Message } \\
\text { - } \quad \text { Display Color = Yellow }\end{array}$ & \\
\hline 2. & $\begin{array}{l}\text { Activate ACK ALARMS Button } \\
\text { on Tank Test } 201 \text { status }\end{array}$ & $\begin{array}{l}\text { Beep } \\
\text { Beep = false } \\
\text { Most Recent Alarm } \\
\text { - Message Status = Acknowledged } \\
\text { - } \quad \text { Display Color = Yellow } \\
\text { - Text Color = Black } \\
\text { Discrete Functional Test Workspace } \\
\text { Discrete - 2001 } \\
\text { - Discrete Icon Blinking = false } \\
\text { - Display Color = YELLOW } \\
\text { - Blink-off Color = (N/A - skip) } \\
\text { Alarm Aux Color = YELLOW } \\
\text { Tank Icon Test-201 } \\
\text { - Icon Blinking = false } \\
\text { - Display Color = YELLOW } \\
\end{array}$ & \\
\hline
\end{tabular}


HNF-4368, Rev. 0

\begin{tabular}{|c|c|c|c|}
\hline Step & Perform & Expected Result & Initial \\
\hline & 7 & $\begin{array}{l}\text { - Blink-off Color }=(\mathrm{N} / \mathrm{A}-\text { skip }) \\
\text { Latest Alarm Message } \\
\text { - Display Color }=\text { Yellow } \\
\text { Continuous Functional Test Workspace } \\
\text { Continuous -2001 } \\
\text { - Cont. Icon Blinking = false } \\
\text { - Display Color }=\text { GREEN } \\
\text { - Blink-off Color = (N/A - skip) } \\
\text { - Alarm Aux Color = TRANSPARENT } \\
\text { Tank Icon Test-201 } \\
\text { - Icon Blinking = false } \\
\text { - Display Color = YELLOW } \\
\text { - Blink-off Color = (N/A - skip) } \\
\text { Latest Alarm Message } \\
\text { - Display Color = Yellow }\end{array}$ & \\
\hline 3. & $\begin{array}{l}\text { Enter } 0 \text { in Dip-switch type-in box } \\
\text { on the Discrete Functional Test } \\
\text { Workspace. }\end{array}$ & $\begin{array}{l}\text { Beep } \\
\text { Beep = false } \\
\begin{array}{l}\text { Most Recent Alarm } \\
\text { Message Status = Alarm Disappears }\end{array} \\
\text { Discrete Functional Test Workspace } \\
\text { Discrete - 2001 } \\
\text { - Discrete Icon Blinking = false } \\
\text { - } \quad \text { Bisplay Color = GREEN } \\
\text { - Alarm Aux Color = TRANSPARENT } \\
\text { Tank Icon Test-201 } \\
\text { - Icon Blinking = false } \\
\text { - Display Color = GREEN } \\
\text { - Blink-off Color = (N/A - skip) } \\
\text { Latest Alarm Message } \\
\text { - Display Color = YELLOW }\end{array}$ & \\
\hline
\end{tabular}


HNF-4368, Rev. 0

\begin{tabular}{|c|c|c|c|}
\hline Step & Perform & Expected Result & Initial \\
\hline & & $\begin{array}{l}\text { Continuous Functional Test Workspace } \\
\text { Continuous -2001 } \\
\text { - } \quad \text { Cont. Icon Blinking = false } \\
\text { - } \quad \text { Display Color = GREEN } \\
\text { - } \quad \text { Blink-off Color = (N/A - skip) } \\
\text { - } \quad \text { Alarm Aux Color = TRANSPARENT } \\
\text { Tank Icon Test-201 } \\
\text { - } \text { Icon Blinking = false } \\
\text { - Display Color = GREEN } \\
\text { - Blink-off Color = (N/A - skip) } \\
\text { Latest Alarm Message } \\
\text { - Display Color = YELLOW }\end{array}$ & 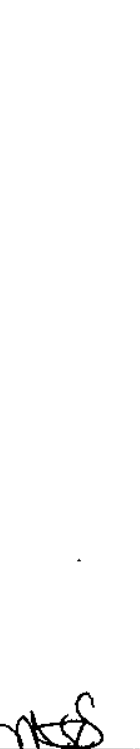 \\
\hline 4. & $\begin{array}{l}\text { Enter a } 17 \text { in Milli-amp type-in } \\
\text { box on the Continuous } \\
\text { Functional Test Workspace }\end{array}$ & $\begin{array}{l}\text { Beep } \\
\text { Beep = true } \\
\text { Most Recent Alarm } \\
\text { - Message Status = ALARM HIGH } \\
\text { - } \quad \text { Display Color = RED } \\
\text { - Text Color = YELLOW } \\
\text { Discrete Functional Test Workspace } \\
\text { Discrete - 2001 } \\
\text { - Discrete Icon Blinking = false } \\
\text { - Display Color = GREEN } \\
\text { - } \quad \text { Alink-off Color = (N/A - skip) } \\
\text { Tank Icon Test-201 } \\
\text { - Icon Blinking = true } \\
\text { - Display Color = RED } \\
\text { - Blink-off Color = GRAY } \\
\text { Latest Alarm Message } \\
\text { - Display Color = YELLOW }\end{array}$ & \\
\hline
\end{tabular}


HNF-4368, Rev. 0

\begin{tabular}{|c|c|c|c|}
\hline Step & Perform & Expected Result & Initial \\
\hline & & $\begin{array}{l}\text { Continuous Functional Test Workspace } \\
\text { Continuous -2001 } \\
\text { - } \text { Cont. Icon Blinking = true } \\
\text { - } \quad \text { Display Color = RED } \\
\text { - Blink-off Color = GRAY } \\
\text { - } \quad \text { Alarm Aux Color = RED } \\
\text { Tank Icon Test-201 } \\
\text { - Icon Blinking = true } \\
\text { - Display Color = RED } \\
\text { - Blink-off Color = GRAY } \\
\text { Latest Alarm Message } \\
\text { - Display Color = RED }\end{array}$ & . \\
\hline 5. & $\begin{array}{l}\text { Enter } 1 \text { in Dip-switch type-in box } \\
\text { on the Discrete Functional Test } \\
\text { Workspace. }\end{array}$ & $\begin{array}{l}\text { Beep } \\
\text { Beep }=\text { true } \\
\text { Most Recent Alarm } \\
\text { Message Status = Create CLOSING } \\
\text { alarm } \\
\text { Display Color = YELLOW } \\
\text { Text Color = RED } \\
\text { Discrete Functional Test Workspace } \\
\text { Discrete - 2001 } \\
\text { - Discrete Icon Blinking = true } \\
\text { Display Color = YELLOW } \\
\text { Blink-off Color = GRAY } \\
\text { Alarm Aux Color = YELLOW } \\
\text { Tank Icon Test-201 } \\
\text { - Icon Blinking = true } \\
\text { - Display Color = RED } \\
\text { Blink-off Color = GRAY } \\
\text { Latest Alarm Message } \\
\text { Display Color = YELLOW }\end{array}$ & \\
\hline
\end{tabular}


HNF-4368, Rev. O

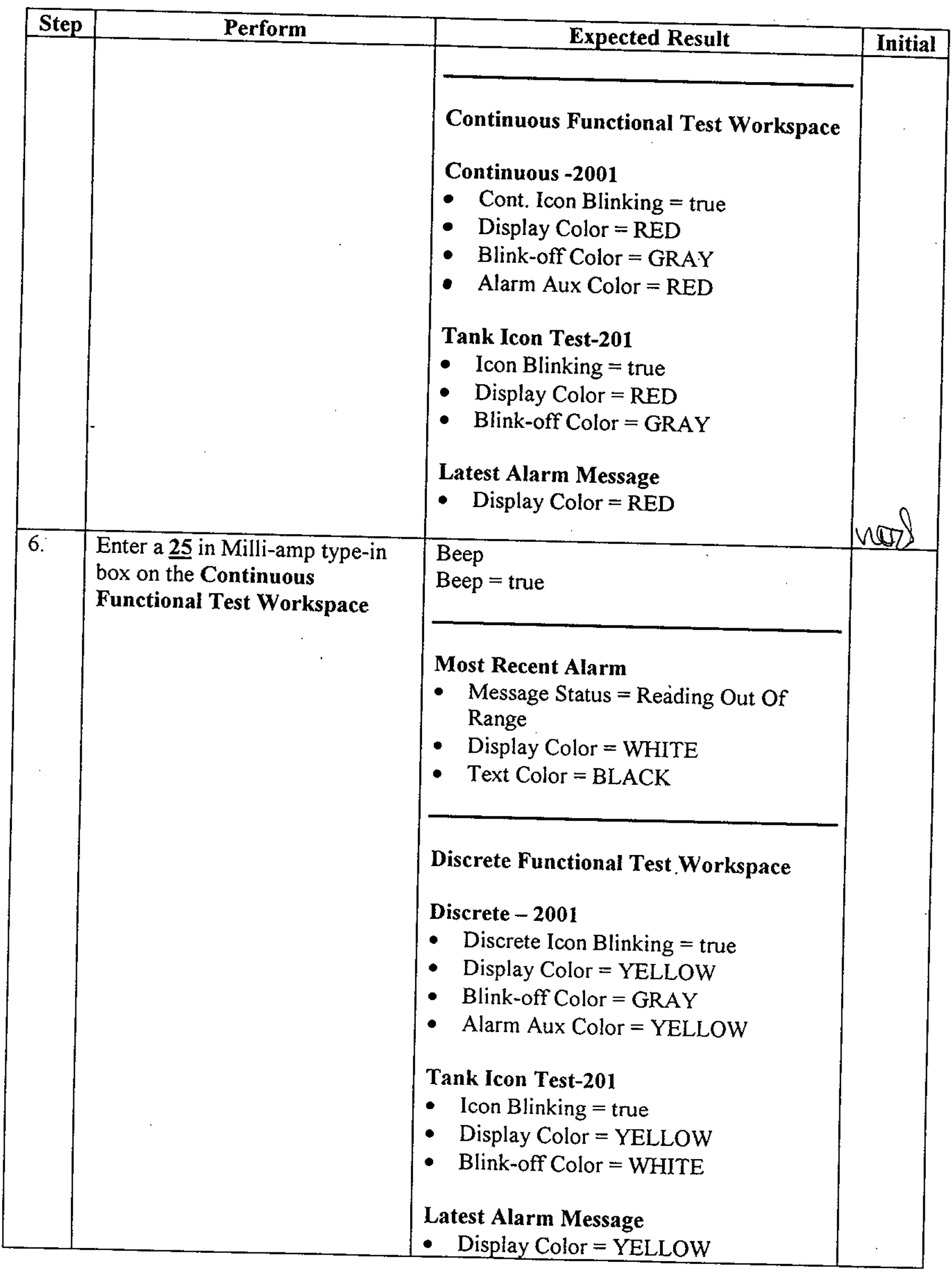


HNF-4368, Rev. 0

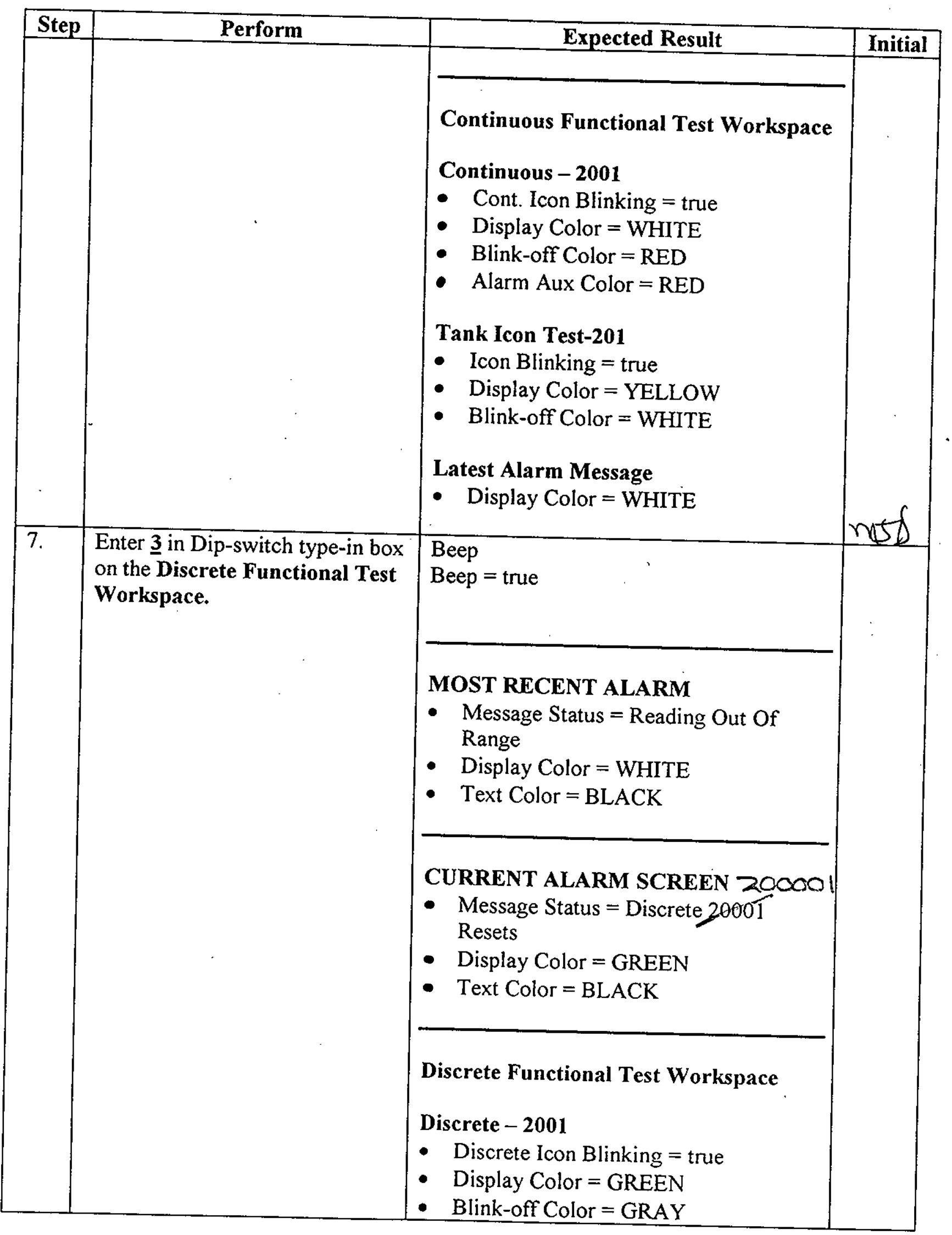


HNF-4368, Rev. 0

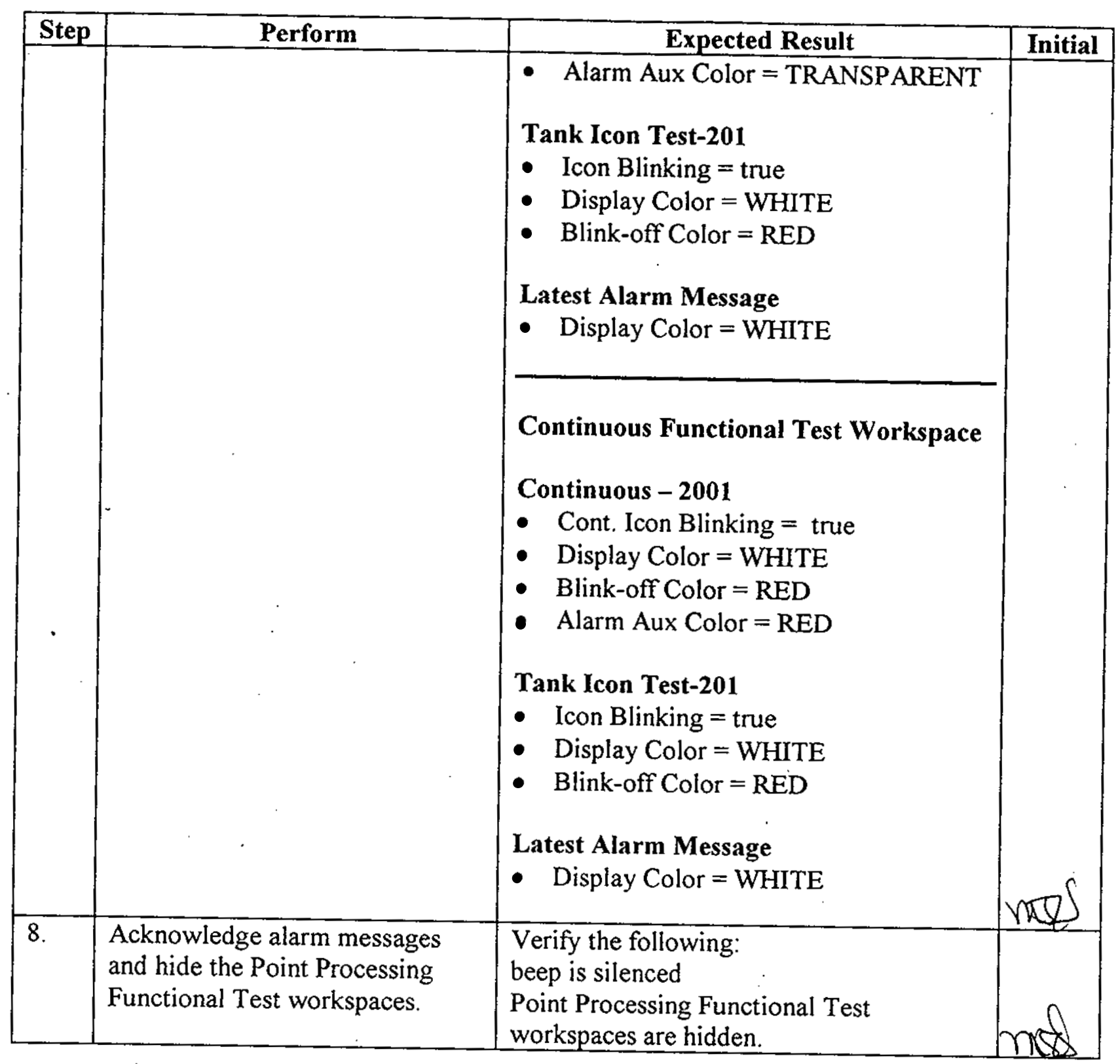


HNF-4368, Rev. 0

\subsection{LOGGING}

\subsubsection{Current}

The data files in this section are created upon system startup and then around midnight are closed and moved to the history directory and another file with the current date is created.

\subsubsection{Alarm Logging}

\begin{tabular}{|c|c|c|c|}
\hline Step & Perform & Expected Result & Initial \\
\hline 1. & $\begin{array}{l}\text { Examine the } \\
\text { almhst_YYYY_MM_DD_HHmm.dat. } \\
\text { Where } \\
\text { YYYY = the year } \\
\mathrm{MM}=\text { the month } \\
\mathrm{DD}=\text { the day } \\
\mathrm{HH}=\text { the hour } \\
\mathrm{mm}=\text { the minute } \\
\text { To examine the files it may be necessary } \\
\text { to stop G2. The directory is located at } \\
\text { f: } 2_{\text {BackedUp }} \text { TMACSDatalCurrent. }\end{array}$ & $\begin{array}{l}\text { Verify the following: } \\
\text { High/low alarm conditions } \\
\text { and resets recorded } \\
\text { Format match the } \\
\text { description given in the } \\
\text { LMSI External Letter, } \\
\text { RGG-SDI-99-001, TMACS } \\
\text { Data File Formats, Release } \\
\text { 11.0. }\end{array}$ & \\
\hline 2. & $\begin{array}{l}\text { Examine the } \\
\text { equip_fail_YYYY_MM_DD_HHmm.dat. } \\
\text { Where } \\
\text { YYYY = the year } \\
\mathrm{MM}=\text { the month } \\
\mathrm{DD}=\text { the day } \\
\mathrm{HH}=\text { the hour } \\
\mathrm{mm}=\text { the minute } \\
\text { To examine the files it may be necessary } \\
\text { to stop G2 } 2^{\infty} \text {. The directory is located at } \\
f: \text { BackedUp } \backslash \text { TMACSDatalCurrent. }\end{array}$ & $\begin{array}{l}\text { Verify the following } \\
\text { - Out-of-instrument-limits } \\
\text { - messages-are recorded., w-Sts } \\
\text { Format match the } \\
\text { description given in the } \\
\text { LMSI External Letter, } \\
\text { RGG-SDI-99-001, TMACS } \\
\text { Data File Formats, } \\
\text { Release 11.0. }\end{array}$ & \\
\hline
\end{tabular}


HNF-4368, Rev. 0

3/30/1999 WHC-SD-WM-TRP-110 Rev 11.0 Test Proc 6: Performance Test Page $\perp$

CPU Use Versus Number of Continuous Points/Sec

Averaging time (minutes) 10 \%

\%

\begin{tabular}{|c|c|c|c|c|c|}
\hline $\begin{array}{l}\text { No. of Cont. } \\
\text { Points/sec }\end{array}$ & & $\begin{array}{l}\text { Average } \\
\text { (10 Min.) }\end{array}$ & $\begin{array}{l}\text { Minimum } \\
\text { (10 Min.) }\end{array}$ & $\begin{array}{l}\text { Maximum } \\
(10 \text { Min.) }\end{array}$ & $\begin{array}{l}\text { Std Dev } \\
\text { (10 Min.) }\end{array}$ \\
\hline BKGD & BKGD & 0.013 & $2.004 e-22$ & 0.424 & $3.89 \mathrm{e} 2 \%$ \\
\hline I/O \& Rule & $\% \mathrm{CPU}$ & 0.049 & $3.011 e-4$ & 0.323 & $1.17 \mathrm{e} 2 \%$ \\
\hline 5 & $\%$ CPU & 2.311 & 2.272 & 2.699 & $2.81 \%$ \\
\hline 10 & $\% \mathrm{CPU}$ & 4.686 & 4.517 & 4.825 & $0.96 \%$ \\
\hline 20 & $\%$ CPU & 8.604 & 8.55 & 11.628 & $3.47 \%$ \\
\hline 30 & $\% \mathrm{CPU}$ & 11.699 & 11.658 & 11.834 & $0.32 \%$ \\
\hline . & & & & & \\
\hline 40 & $\%$ CPU & 15.747 & 15.495 & 16.2 & $1.04 \%$ \\
\hline 50 & $\% \mathrm{CPU}$ & 19.505 & 19.44 & 19.935 & $0.30 \%$ \\
\hline Memory MB & 91.085 & & Pts/sec & $\%$ cpu/pt/sec & \\
\hline Delta & 0.0 & & 5 & 0.452 & \\
\hline Pt. Proc. & true & & 10 & 0.464 & \\
\hline Alarm Proc. & true & & 20 & 0.428 & \\
\hline ROC Proc. & true & & 30 & 0.388 & \\
\hline Log Proc. & true & & 40 & 0.392 & \\
\hline & & & 50 & 0.389 & \\
\hline Started: & $16: 123 / 30$ & Completed: & $18: 393 / 30$ & Elapsed: & 148 of 98 \\
\hline
\end{tabular}

Section 6.7 .1 steps $2 \xi 3 \quad 3 / 31 / 99$ 
HNF-4368, Rev. 0

\subsubsection{Discrete Sensor Data Logging}

\begin{tabular}{|c|c|c|c|}
\hline Step & Perform & Expected Result & Initial \\
\hline 1. & $\begin{array}{l}\text { Examine the } \\
\text { discrete_sensor_history_YYYY_MMDD.ascii. } \\
\text { Where } \\
\text { YYYY - is the year created } \\
\qquad \mathrm{MM} \text { - is the month created } \\
\quad \mathrm{DD} \text { - is the day created } \\
\text { To examine the file it may be necessary to stop } \\
\text { G2 } 2^{\otimes} \text {. The directory is located at } \\
f: \text { BackedUp } 1 \text { TMACSDatalCurrent. }\end{array}$ & $\begin{array}{l}\text { Verify the following: } \\
\text { - Reading messages are } \\
\text { being recorded properly. } \\
\text { Format match the } \\
\text { description given in the } \\
\text { LMSI External Letter, } \\
\text { RGG-SDI-99-001, } \\
\text { TMACS Data File } \\
\text { Formats, Release 11.0. }\end{array}$ & \\
\hline
\end{tabular}

\subsubsection{Continuous Sensor Data Logging}

Continuous sensor history is recorded in the continuous_sensor_history_YYYY_MMDD.ascii file where

YYYY - is the year that the file was created.

$\mathrm{MM}$ - is the month that the file was created.

$\mathrm{DD}$ - is the day that the file was created.

To examine the file it may be necessary to stop $\mathrm{G} 2{ }^{\infty}$. The directory is:

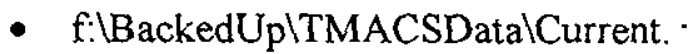

\begin{tabular}{|c|c|c|c|}
\hline Step & Perform & Expected Result & Initial \\
\hline 1. & $\begin{array}{l}\text { Examine the continuous_sensor_history } \\
\text { _YYYY_MMDD.ascii. } \\
\text { Where } \\
\text { YYYY - is the year created } \\
\text { MM - is the month created } \\
\text { DD - is the day created } \\
\text { To examine the file it may be necessary to stop } \\
\text { G2 } \\
\text { f: Thacked The directory is located at } \\
\text { W }\end{array}$ & $\begin{array}{l}\text { Verify the following: } \\
\text { - Reading messages are } \\
\text { being recorded properly. } \\
\text { - Format match the } \\
\text { description given in the } \\
\text { LMSI External Letter, } \\
\text { RGG-SDI-99-001, } \\
\text { TMACS Data File } \\
\text { Formats, Release 11.0. }\end{array}$ & $\begin{array}{c}0 . R . \\
3 / 3 / / 29\end{array}$ \\
\hline
\end{tabular}

\subsubsection{Nightly File Creations}

Eight files are created nightly by TMACS (rdbms files are created around 4:00 AM, all others created around 12:00 AM) 
HNF-4368, Rev. 0

\begin{tabular}{|c|c|c|c|}
\hline Step & Perform & Verify & Initial \\
\hline 1. & $\begin{array}{l}\text { Let the system run over } \\
\text { night. (Note: Test } \\
\text { Director may opt to change } \\
\text { the system clock to } \\
\text { simulate overnight. This } \\
\text { requires time periods } \\
\text { around midnight and } \\
4 \text { AM) } \\
\text { Check the location } \\
\text { : } \text { BackedUp\TMACSDatal } \\
\text { History to determine if the } \\
\text { files have been created. }\end{array}$ & $\begin{array}{l}\text { Verify that the following flat files are created: } \\
\text { - almhst_yyyy_mmdd_mmss.dat } \\
\text { - continuous_sensor_history yyyy_mmdd.ascii } \\
\text { - discrete_sensor_history_yyyy_mmdd.ascii } \\
\text { - equip_fail_yyyy_mmdd_mmss.dat } \\
\text { - perf_data_yyyy_mmdd.dat } \\
\text { - test_tank_history_yyyy_mmdd.ascii } \\
\text { - dst_data_yyyy_mmdd_mmss.rdbms_z } \\
\text { - sst_data_yyyy_mmdd_mmss.rdbms } \\
\text { where: } \\
\text { yyyy = the year } \\
\text { mm = the month } \\
\text { dd = the day } \\
\text { hh }=\text { the hour } \\
\text { mm = the minute } \\
\text { Verify that the fields in the files.match the } \\
\text { description given in the LMSI External Letter, } \\
\text { RGG-SDI-99-001,TMACS Data File Formats, } \\
\text { Release } 11.0 \text {. }\end{array}$ & $\begin{array}{l}\text { O.R. } \\
3 / 31 / 99\end{array}$ \\
\hline
\end{tabular}

\subsection{PERFORMACE}

\subsubsection{CPU Use Vs Number of Continuous Points/Sec Performance Test}

\begin{tabular}{|c|c|c|c|}
\hline Step & Perform & Expected Result & Initial \\
\hline 1. & $\begin{array}{l}\text { On the Point Processing } \\
\text { Performance Test workspace click } \\
\text { on the "CPU Use Versus Number } \\
\text { of Continuous Points/Sec" } \\
\text { button. }\end{array}$ & Verify the correct workspace is shown. & $\begin{array}{l}\sigma \cdot R \\
3 / 31 / 99\end{array}$ \\
\hline 2. & $\begin{array}{l}\text { Click on the "Start Performance } \\
\text { Test" button. } \\
\text { After the Test Running box turns } \\
\text { to FALSE examine the results. } \\
\text { (The test will take about } \\
20 \text { minutes to run) }\end{array}$ & $\begin{array}{l}\text { Verify the test runs and that the } \\
\% \mathrm{CPU} / \mathrm{pt} / \mathrm{sec} \text { values are less than } 0.94 \\
\text { for all values of points/second. }\end{array}$ & $\begin{array}{c}0.21 \\
3 / 31 / 99\end{array}$ \\
\hline 3. & Click on the "Print" button. & $\begin{array}{l}\text { Verify that the workspace prints. } \\
\text { Attach the printout to this test procedure. }\end{array}$ & $\begin{array}{l}0.12 \\
3 / 31 / 99\end{array}$ \\
\hline 4. & $\begin{array}{l}\text { Hide the Performance Test } \\
\text { workspace }(s)\end{array}$ & Verify the workspace(s) is hidden. & $\begin{array}{l}0.12 \\
3 / 31 / 99\end{array}$ \\
\hline
\end{tabular}


HNF-4368, Rev, 0

3/30/1999 WHC-SD-WM-TRP-110 Rev 11.0 Test Proc 6: Performance Test Page $\mathcal{Q}$

CPU Use Versus Number of Discrete PointsiSec

\%

Averaging time (minutes) 10

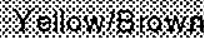

\%细的

\begin{tabular}{|c|c|c|c|c|c|}
\hline $\begin{array}{l}\text { No. of } \\
\text { Dscrt. }\end{array}$ & & $\begin{array}{l}\text { Average } \\
\text { (10 Min.) }\end{array}$ & $\begin{array}{l}\text { Minimum } \\
(10 \text { Min.) }\end{array}$ & $\begin{array}{l}\text { Maximum } \\
\text { (10 Min.) }\end{array}$ & $\begin{array}{c}\text { Std Dev } \\
\text { (10 Min.) }\end{array}$ \\
\hline BKGD & BKGD & 0.005 & $1.344 \mathrm{e}-28$ & 0.31 & $5.52 \mathrm{e} 2 \%$ \\
\hline I/O \& Rule & $\% \mathrm{CPU}$ & 0.034 & $2.995 e-4$ & 0.416 & $1.74 \mathrm{e} 2 \%$ \\
\hline 5 & $\% \mathrm{CPU}$ & 1.56 & 1.5 & 1.833 & $3.72 \%$ \\
\hline 10 & $\%$ CPU & 3.107 & 3.095 & 3.243 & $0.75 \%$ \\
\hline 20 & $\% \mathrm{CPU}$ & 4.691 & 4.655 & 4.825 & $0.80 \%$ \\
\hline 30 & $\% \mathrm{CPU}$ & 7.829 & 7.788 & 8.222 & $0.67 \%$ \\
\hline 40 & $\% \mathrm{CPU}$ & 9.468 & 9.347 & 12.614 & $3.29 \%$ \\
\hline 50 & $\%$ CPU & 12.524 & 12.48 & 12.656 & $0.32 \%$ \\
\hline Memory MB & 91.429 & & $\mathrm{Pts} / \mathrm{sec}$ & $\% \mathrm{cpu} / \mathrm{pt} / \mathrm{sec}$ & \\
\hline Delta & N.A. & & 5 & 0.305 & \\
\hline Pt. Proc. & true & & 10 & 0.307 & \\
\hline Alarm Proc. & true & & 20 & 0.233 & \\
\hline ROC Proc. & N.A & & 30 & 0.260 & \\
\hline Log Proc. & true & & 40 & 0.236 & \\
\hline & & & 50 & 0.250 & \\
\hline Started: & $18: 413 / 30$ & Completed: & $21: 93 / 30$ & Elapsed: & 148 of 98 \\
\hline
\end{tabular}

socrion 6.7 .2 steps $2 \xi^{3} \quad 3 / 31 / 99$ 
HNF-4368, Rev. 0

3/30/1999 WHC-SD-WM-TRP-110 Rev 11.0 Test Proc 6: Performance Test Page _

CPU Use Versus Point-Processing Function for

Continuous Points

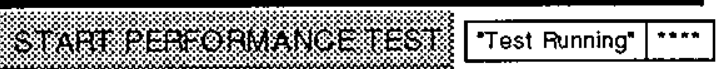

No. of Pts/sec to Process 50

Averaging time (minutes) 10

\begin{tabular}{|c|c|c|c|c|c|}
\hline $\begin{array}{l}\text { Pt. Proc. } \\
\text { Function }\end{array}$ & & $\begin{array}{l}\text { Average } \\
\text { (10 Min.) }\end{array}$ & $\begin{array}{l}\text { Minimum } \\
\text { (10 Min.) }\end{array}$ & $\begin{array}{l}\text { Maximum } \\
\text { (10 Min.) }\end{array}$ & $\begin{array}{c}\text { Std Dev } \\
\text { (10 Min.) }\end{array}$ \\
\hline All Funcs & $\% \mathrm{CPU}$ & 19.585 & 19.526 & 19.747 & $0.25 \%$ \\
\hline w/o Logging & $\% \mathrm{CPU}$ & 12.76 & 12.548 & 13.267 & $1.05 \%$ \\
\hline w/o ROC & $\% \mathrm{CPU}$ & 10.296 & 10.169 & 10.635 & $0.91 \%$ \\
\hline w/o Alarm & $\% \mathrm{CPU}$ & 10.219 & 10.168 & 10.359 & $0.43 \%$ \\
\hline$<$ Delta & $\% \mathrm{CPU}$ & 7.091 & 7.05 & 7.52 & $0.81 \%$ \\
\hline w/o Pt Proc & $\% \mathrm{CPU}$ & 2.385 & 2.355 & 2.525 & $1.71 \%$ \\
\hline w/o Rule & $\% \mathrm{CPU}$ & 0.905 & 0.803 & 1.282 & $9.86 \%$ \\
\hline BKGD & $\% \mathrm{CPU}$ & 0.016 & $6.026 e-12$ & 0.47 & $3.38 \mathrm{e} 2 \%$ \\
\hline & Memory & 91.465 & 91.437 & 91.477 & $0.02 \%$ \\
\hline
\end{tabular}

\begin{tabular}{|c|c|c|c|c|c|}
\hline $\begin{array}{c}\text { Summary } \\
\text { Breakdown }\end{array}$ & $\% \mathrm{cpu}$ & & $\begin{array}{c}\text { Pt. Proc. } \\
\text { Breakdown }\end{array}$ & \%cpu/pt/sec & \\
\hline Pt Proc & 17.20 & $87.8 \%$ & Update Pt. & 0.09 & $27.4 \%$ \\
\hline Rule Proc & 1.48 & $7.6 \%$ & Delta Check & 0.06 & $18.2 \%$ \\
\hline I/O Proc & 0.89 & $4.5 \%$ & Alarm Chk & 0.00 & $0.5 \%$ \\
\hline Bkgd & 0.02 & $0.1 \%$ & ROC Check & 0.05 & $14.3 \%$ \\
\hline & & & Log to Disk & 0.14 & $39.7 \%$ \\
\hline & & & & & 0.34 \\
\hline Total: & 19.59 & $100.0 \%$ & Total: & $100.0 \%$ \\
\hline & & & & & \\
\hline Pts/sec: & 50 & \# Cont Pts: & 2190 & \# Dscrt Pts: & 108 \\
\hline & & & & & \\
\hline Started: & $21: 103 / 30$ & Completed: & $23: 73 / 30$ & Elapsed: & 117 of 97 \\
\hline
\end{tabular}

$$
\text { section } 6.7 .3 \text { step } 3 \quad 3 / 31 / 99
$$


HNF-4368, Rev. 0

6.7.2 CPU Use Vs Number of Discrete Points/Sec Performance Test

\begin{tabular}{|c|c|c|c|}
\hline Step & Perform & Expected Result & Initial \\
\hline 1. & $\begin{array}{l}\text { On the Point Processing } \\
\text { Performance Test workspace click } \\
\text { on the "CPU Use Versus Number } \\
\text { of Discrete Points/Sec" button. }\end{array}$ & $\begin{array}{l}\text { Verify the correct Performance Test } \\
\text { workspace is shown. }\end{array}$ & $\begin{array}{l}0.12 \\
3 / 3 / 199\end{array}$ \\
\hline 2. & $\begin{array}{l}\text { Click on the "Start Performance } \\
\text { Test" button. } \\
\text { After the Test Running box turns } \\
\text { to FALSE examine the results. } \\
\text { (The test will take about } \\
20 \text { minutes to run) }\end{array}$ & $\begin{array}{l}\text { Verify that the test runs and that the } \\
\% \mathrm{CPU} / \mathrm{pt} / \mathrm{sec} \text { values are less than } 0.82 \\
\text { for all values of points/second. }\end{array}$ & $\begin{array}{l}O . R . \\
3 / 3 / 1 / 99\end{array}$ \\
\hline 3. & Click on the "Print" button. & $\begin{array}{l}\text { Verify that the workspace prints. } \\
\text { Attach the printout to this test procedure. }\end{array}$ & $\begin{array}{l}0.72 \\
3 / 3 / 199\end{array}$ \\
\hline 4. & $\begin{array}{l}\text { Hide the Performance Test } \\
\text { workspace(s) }\end{array}$ & Verify the workspace(s) is hidden. & $\begin{array}{l}0.02 \\
3 / 31 / 99\end{array}$ \\
\hline
\end{tabular}

6.7.3 CPU Use Vs Pt-Processing Function for Continuous Points Performance Test

\begin{tabular}{|c|c|c|c|}
\hline Step & Perform & Expected Result & Initial \\
\hline 1. & $\begin{array}{l}\text { On the Point Processing } \\
\text { Performance Test workspace } \\
\text { click on the Click on the } \\
\text { "CPU Use Versus Point- } \\
\text { Processing Function for } \\
\text { Continuous Points" button. }\end{array}$ & $\begin{array}{l}\text { Verify the correct Performance Test } \\
\text { workspace is shown. }\end{array}$ & $\begin{array}{l}0 . R \\
3 / 31 / 99\end{array}$ \\
\hline 2. & $\begin{array}{l}\text { Click on the "Start } \\
\text { Performance Test" button. } \\
\text { After the Test Running box } \\
\text { turns to FALSE examine the } \\
\text { results. (The test will take } \\
\text { about } 20 \text { minutes to run) }\end{array}$ & $\begin{array}{l}\text { Verify that the test runs and that for each } \\
\text { Point Processing Breakdown that the } \\
\text { following criteria are met. } \\
\text { Update Pt. the \%CPU per points } / \mathrm{sec}<0.23 \\
\text { Delta Check the \%CPU per points } / \mathrm{sec}<0.15 \\
\text { Alarm Check the \%CPU per points } / \mathrm{sec}<0.07 \\
\text { ROC Check the \%CPU per points } / \mathrm{sec}<0.12 \\
\text { Log to Disk the \%CPU per points } / \mathrm{sec}<0.57\end{array}$ & $\begin{array}{l}\text { S.R. } \\
3 / 31 / 99\end{array}$ \\
\hline 3. & Click on the "Print" button. & $\begin{array}{l}\text { Verify that the workspace prints. } \\
\text { Attach the printout to this test procedure. }\end{array}$ & $\begin{array}{l}0.12 \\
3 / 31 / 99\end{array}$ \\
\hline 4. & $\begin{array}{l}\text { Hide the Performance Test } \\
\text { workspace }\end{array}$ & Verify the workspace is hidden. & $\begin{array}{l}0 . R \\
3 / 31 / 99\end{array}$ \\
\hline
\end{tabular}




\section{HNF-4368, Rev. 0}

3/31/1999 WHC-SD-WM-TRP-110 Rev 11.0 Test Proc 6: Performance Test Page 4

CPU Use Versus Point-Processing Function for

Discrete Points

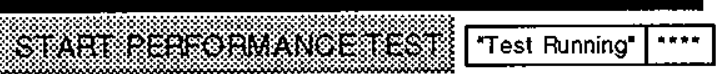

No. of Pts/sec to Process 50

Averaging time (minutes) 10

8.

\begin{tabular}{|c|c|c|c|c|c|}
\hline $\begin{array}{l}\text { Pt. Proc. } \\
\text { Function }\end{array}$ & & $\begin{array}{l}\text { Average } \\
\text { (10 Min.) }\end{array}$ & $\begin{array}{l}\text { Minimum } \\
\text { (10 Min.) }\end{array}$ & $\begin{array}{l}\text { Maximum } \\
\text { (10 Min.) }\end{array}$ & $\begin{array}{l}\text { Std Dev } \\
\text { (10 Min.) }\end{array}$ \\
\hline All Funcs & $\% \mathrm{CPU}$ & 12.527 & 12.48 & 12.678 & $0.34 \%$ \\
\hline w/o Logging & $\% \mathrm{CPU}$ & 6.26 & 6.2 & 6.491 & $0.84 \%$ \\
\hline w/o Alarm & $\%$ CPU & 7.02 & 6.242 & 7.676 & $5.77 \%$ \\
\hline w/o Pt Proc & $\% \mathrm{CPU}$ & 1.57 & 1.5 & 2.023 & $4.36 \%$ \\
\hline w/o Rule & $\% \mathrm{CPU}$ & 0.035 & $3.98 e-13$ & 1.56 & $4.35 \mathrm{e} 2 \%$ \\
\hline BKGD & $\% \mathrm{CPU}$ & 0.013 & $1.212 \mathrm{e}-28$ & .0 .46 & $3.97 e 2 \%$ \\
\hline & Memory & 91.65 & 91.52 & 92.407 & $0.31 \%$ \\
\hline & & & & & \\
\hline
\end{tabular}

\begin{tabular}{|c|c|c|c|c|c|}
\hline $\begin{array}{c}\text { Summary } \\
\text { Breakdown }\end{array}$ & \%cpu & & $\begin{array}{c}\text { Pt. Proc. } \\
\text { Breakdown }\end{array}$ & \%cpu/pt/sec & \\
\hline Pt Proc & 10.96 & $87.5 \%$ & Update Pt. & 0.11 & $49.7 \%$ \\
\hline Rule Proc & 1.54 & $12.3 \%$ & Alarm Chk & -0.02 & $-6.9 \%$ \\
\hline I/O Proc & 0.02 & $0.2 \%$ & Log to Disk & 0.13 & $57.2 \%$ \\
\hline Bkgd & 0.01 & $0.1 \%$ & & & \\
\hline & & & & & \\
\hline Total: & 12.53 & $100.0 \%$ & Total: & 0.22 & $100.0 \%$ \\
\hline & & & & & \\
\hline Pts/sec: & 50 & \# Cont Pts: & 2160 & \# Dscrt Pts: & 108 \\
\hline & & & & & \\
\hline Started: & $23: 93 / 30$ & Completed: & $1: 123 / 31$ & Elapsed: & 123 of 73 \\
\hline
\end{tabular}

section 6.7.4 step $2: 3$ 3/31/99 
HNF-4368, Rev. 0

6.7.4 CPU Use Vs Point-Processing Function for Discrete Points Performance Test

\begin{tabular}{|c|c|c|c|}
\hline Step & Perform & Expected Result & Initial \\
\hline I. & $\begin{array}{l}\text { On the Point Processing } \\
\text { Performance Test } \\
\text { workspace click on the } \\
\text { Click on the "CPU Use } \\
\text { Versus Point-Processing } \\
\text { Function for Discrete } \\
\text { Points" button. }\end{array}$ & $\begin{array}{l}\text { Verify the correct Performance Test workspace is } \\
\text { shown. }\end{array}$ & $\begin{array}{l}0.12 . \\
3 / 31 / 99\end{array}$ \\
\hline 2. & $\begin{array}{l}\text { Click on the "Start } \\
\text { Performance Test" button. } \\
\text { After the Test Running } \\
\text { box turns to FALSE } \\
\text { examine the results. (The } \\
\text { test will take about } \\
20 \text { minutes to run) }\end{array}$ & $\begin{array}{l}\text { Verify that the test runs and that for each Point } \\
\text { Processing Breakdown that the following criteria } \\
\text { are met. } \\
\text { for Update Pt. the } \% \text { CPU per points } / \mathrm{sec}<0.28 \\
\text { for Alarm Check the } \% \text { CPU per points } / \mathrm{sec}<0.07 \\
\text { for Log to Disk the } \% \text { CPU per points } / \mathrm{sec}<0.57\end{array}$ & $\begin{array}{l}0.12 \\
3 / 31 / 99\end{array}$ \\
\hline 3. & $\begin{array}{l}\text { Click on the "Print" } \\
\text { button. }\end{array}$ & $\begin{array}{l}\text { Verify that the workspace prints. } \\
\text { Attach the printout to this test procedure. }\end{array}$ & $\begin{array}{l}0.21 \\
3 / 31 / 99\end{array}$ \\
\hline 4. & $\begin{array}{l}\text { Hide the Performance } \\
\text { Test workspace }\end{array}$ & Verify the workspace is hidden. & $\begin{array}{c}0.12 \\
3 / 31 / 99\end{array}$ \\
\hline
\end{tabular}

\subsection{SERVICE REQUESTS}

\subsubsection{SR 80 - Temperature values hard to read}

\begin{tabular}{|l|l|c|c|}
\hline Step & \multicolumn{1}{|c|}{ Perform } & Expected Result & Initial \\
\hline 1. & $\begin{array}{l}\text { Select a tank at random and } \\
\text { call up it's workspace. }\end{array}$ & Verify that the temperature values are readable. & $\begin{array}{c}0.2 . \\
3 / 31 / 99\end{array}$ \\
\hline
\end{tabular}

\subsubsection{SR 82 - Tank icons hard to read}

\begin{tabular}{|c|l|c|c|}
\hline Step & \multicolumn{1}{|c|}{ Perform } & Expected Result & Initial \\
\hline 1. & $\begin{array}{l}\text { View the Hanford Tank } \\
\text { Farm Facilities workspace. }\end{array}$ & Verify that the tank numbers are readable. & $0 . R \cdot$ \\
\end{tabular}

\subsubsection{9-C-106 Sensor Configuration Changes}

\begin{tabular}{|l|l|l|c|}
\hline Step & \multicolumn{1}{|c|}{ Perform } & \multicolumn{1}{|c|}{ Expected Result } & Initial \\
\hline 1. & $\begin{array}{l}\text { Call up the workspace for } \\
\text { Tank C } 106 .\end{array}$ & $\begin{array}{l}\text { Verify that the pressure sensor is associated with } \\
\text { Riser 1. }\end{array}$ & \begin{tabular}{c}
$0 . R$. \\
$3 / 31 / 99$ \\
\hline
\end{tabular}
\end{tabular}




\subsubsection{SR 104-Make TMACS colors readable}

\begin{tabular}{|l|l|l|c|}
\hline Step & \multicolumn{1}{|c|}{ Perform } & \multicolumn{1}{c|}{ Expected Result } & Initial \\
\hline 1. & $\begin{array}{l}\text { Select the Display Current } \\
\text { Alarm button on the main } \\
\text { screen. }\end{array}$ & $\begin{array}{l}\text { Verify that the Current Alarms screen is } \\
\text { displayed and that the wording for the alarms is } \\
\text { readable. (May have to generated some alarms.) }\end{array}$ & $3 / 8 / / 99$ \\
\hline
\end{tabular}

\subsubsection{SR 114-Convert TX Farm Trend Graphs To Trend Charts}

\begin{tabular}{|c|c|c|c|}
\hline Step & Perform & Verify & Initial \\
\hline 1. & $\begin{array}{l}\text { Run an inspect command } \\
\text { to display the class for the } \\
\text { Trends in the TX farm. }\end{array}$ & Verify that the trends are identified as charts. & $\begin{array}{c}0.12 \\
3 / 31 / 99\end{array}$ \\
\hline 2. & $\begin{array}{l}\text { Display a few individual } \\
\text { sensor trends at random } \\
\text { from the TX farm. }\end{array}$ & $\begin{array}{l}\text { Verify that the trends are properly displayed and } \\
\text { that the data displayed is appropriate for the } \\
\text { sensor chosen. }\end{array}$ & $\begin{array}{l}0.12 \\
3 / 2199\end{array}$ \\
\hline 3. & $\begin{array}{l}\text { Display a few selectable } \\
\text { sensor trends at random } \\
\text { from the TX farm. }\end{array}$ & $\begin{array}{l}\text { Verify that the trends are properly displayed and } \\
\text { that the data displayed is appropriate for the } \\
\text { sensors chosen. }\end{array}$ & $\begin{array}{c}0.21 \\
3 / 31 / 99\end{array}$ \\
\hline
\end{tabular}

\subsubsection{9 - Upgrade All Selectable Trend Graphs To Trend Charts}

\begin{tabular}{|c|c|c|c|}
\hline Step & Perform & Verify & Initial \\
\hline 1. & $\begin{array}{l}\text { Run an inspect command } \\
\text { to display workspaces with } \\
\text { trend graphs. }\end{array}$ & Verify that none are found. & $\begin{array}{l}0.12 \\
3 / 31 / 99\end{array}$ \\
\hline 2. & $\begin{array}{l}\text { Display a few individual } \\
\text { sensor trends at random }\end{array}$ & $\begin{array}{l}\text { Verify that the trends are properly displayed and } \\
\text { that the data displayed is appropriate for the } \\
\text { sensor chosen. }\end{array}$ & $\begin{array}{l}0 \cdot R \\
3 / 3 / / 9\end{array}$ \\
\hline 3. & $\begin{array}{l}\text { Display a few selectable } \\
\text { sensor trends at random. }\end{array}$ & $\begin{array}{l}\text { Verify that the trends are properly displayed and } \\
\text { that the data displayed is appropriate for the } \\
\text { sensors chosen. }\end{array}$ & $\begin{array}{l}0.12 \\
3 / 31 / 99\end{array}$ \\
\hline
\end{tabular}

\subsubsection{SR $458-$ Change the time that the nightly flat files are created}

\begin{tabular}{|c|c|c|c|}
\hline Step & Perform & Verify & Initial \\
\hline 1. & $\begin{array}{l}\text { Let the system run over } \\
\text { night. (Note: Test } \\
\text { Director may opt to change } \\
\text { the system clock to } \\
\text { simulate overnight. This } \\
\text { requires time periods } \\
\text { around midnight and } \\
4 \text { AM) } \\
\text { Check the location }\end{array}$ & $\begin{array}{l}\text { Verify that the following flat files are created: } \\
\text { almhst_yyyy_mmdd_mmss.dat } \\
\text { continuous_sensor_history yyyy_mmdd.ascii } \\
\text { discrete_sensor_history_yyyy_mmdd.ascii } \\
\text { equip_fail_yyyy_mmdd_mmss.dat } \\
\text { perf_data_yyyy_mmdd.dat } \\
\text { test_tank_history_yyyy_mmdd.ascii } \\
\text { dst_data_yyyy_mmdd_mmss.rdbms } \\
\text { sst_data_yyyy_mmdd_mmss.rdbms }\end{array}$ & $\begin{array}{c}0 . R \\
3 / 31 / 99\end{array}$ \\
\hline
\end{tabular}


HNF-4368, Rev. 0

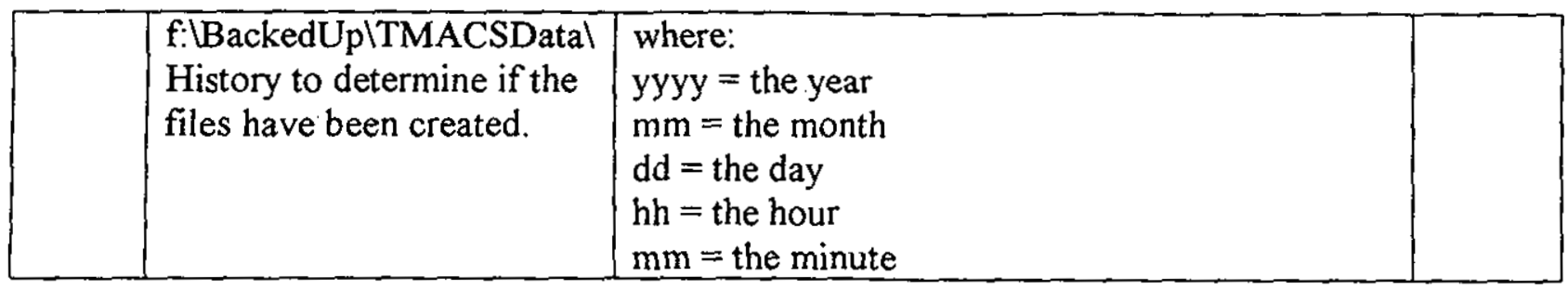

6.8.8 SR 471-Sensor Trends display sensor identifier as tag list identifier

\begin{tabular}{|l|l|l|c|}
\hline Step & \multicolumn{1}{|c|}{ Perform } & \multicolumn{1}{c|}{ Verify } & Initial \\
\hline 1. & $\begin{array}{l}\text { Select at random several } \\
\text { individual sensor trends. }\end{array}$ & $\begin{array}{l}\text { Verify that the sensor tag name is displayed and } \\
\text { that it matches the tag list. }\end{array}$ & $\begin{array}{c}0 . R \cdot \\
3 / 31 / 29\end{array}$ \\
\hline
\end{tabular}

\subsubsection{SR 660 - Convert TMACS from UNIXTM to WindowsNT'M}

Running the test procedures in the previous sections completes this service request.

\subsubsection{SR 704 - Redirection of Y/O Drivers from Production to Development}

\begin{tabular}{|l|l|c|c|}
\hline Step & \multicolumn{1}{|c|}{ Perform } & \multicolumn{1}{c|}{ Verify } & \multicolumn{1}{c|}{ Initial } \\
\hline 1. & $\begin{array}{l}\text { Use the inspect command } \\
\text { to display the GSIrm } \\
\text { connection configuration } \\
\text { attribute of the } \\
\text { GSI Interface objects for } \\
\text { both development and } \\
\text { production. (Except for the } \\
\text { ODBC interface which is } \\
\text { limited to TMACSPROD } \\
\text { due to licensing } \\
\text { restrictions.) }\end{array}$ & $\begin{array}{l}\text { Verify that the tcp-ip-host is identified as "local } \\
\text { host". }\end{array}$ & $0 . R \cdot$ \\
\end{tabular}




\subsubsection{SR $748-$ Enraf $^{2}$ Drivers polls with incorrect message}

\begin{tabular}{|c|c|c|c|}
\hline Step & Perform & Verify & Initial \\
\hline 1. & $\begin{array}{l}\text { While the Enraf bridge } \\
\text { and } G 2^{\circledR} \text { are nunning, } \\
\text { connect the serial } \\
\text { analyzer and the } \\
\text { ENRAF emulator to the } \\
\text { appropriate serial port. } \\
\text { Enable and disable the } \\
\text { gsi interface associated } \\
\text { with the ENRAF } \\
\text { Note: If using a enraf } \\
\text { connected to a code- } \\
\text { operated switch then the } \\
\text { transmitted message will } \\
\text { be preceded with the } \\
\text { arming character } \\
\text { (<SOH>, hex or decimal } \\
\text { oI) followed by line } \\
\text { number which is an } \\
\text { ASCII 0-7 }\end{array}$ & $\begin{array}{l}\text { Verify that the serial analyzer is displaying the } \\
\text { proper Embedded Host Command to the Enraf } \\
\text { CIU. The B-record command format from } \\
\text { TMACS to the CIU is: } \\
<\text { STX }>\text { [CIU][Gauge][Instrument][Record] }<\text { ETX }> \\
\text { [BCC] } \\
\text { The fields are defined as follows: } \\
<\text { STX }>\text { - Start Text Character, hex or dec } 02 \\
\text { [CIU] - CIU Address, ASCII digits } 0-9 \\
\text { [Gauge] - Gauge Address. ASCII digits } 00-99 \\
\text { [Instrument] - Type of Instrument, "B" for type } \\
954 \text { gauge } \\
\text { [Record] - Type of Record, "B" for value and } \\
\text { alarm status } \\
<\text { ETX }>- \text { End of Text Character, hex or dec } 03 \\
\text { [BCC] - Block Check Character }\end{array}$ & $\begin{array}{l}0 . R . \\
3 / 31 / 99\end{array}$ \\
\hline & & $\begin{array}{l}\text { Verify that the serial analyzer is displaying the } \\
\text { command response: } \\
<\text { STX }>\text { [CIU][Gauge][Record][Instr][AS][LS][Le } \\
\text { vel] } \angle E T X>[B C C] \\
\text { where the first } 5 \text { fields and last } 2 \text { fields are the } \\
\text { same as in the Host command format. The other } \\
\text { fields are defined as: } \\
\text { [AS] - Alarm Status (can be "B", "C", "F", "H", } \\
\text { "L" or "_"). } \\
\text { [LS] - Level Status (can be "B", "C", "D", "F", } \\
\text { "L", "R", "T", "W" or "-"). } \\
\text { [Level] - Level Value in 1/100th of an inch in the } \\
\text { form of NNNNNN (6 decimal digits with implied } \\
\text { decimal point after the fourth digit). }\end{array}$ & $\begin{array}{l}0.21 \\
3 / 31 / 99\end{array}$ \\
\hline
\end{tabular}




\subsubsection{SR 749 - TMACS Alarm Printer gsi_interface configuration}

\begin{tabular}{|l|l|l|c|}
\hline Step & \multicolumn{1}{|c|}{ Perform } & \multicolumn{1}{c|}{ Verify } & \multicolumn{1}{c|}{ Initial } \\
\hline I. & $\begin{array}{l}\text { Display the table for the } \\
\text { TMACS Alarm Printer } \\
\text { gsi interface. }\end{array}$ & $\begin{array}{l}\text { Verify that the gsitm connection configuration } \\
\text { attribute identifies the TCP-IP Host as local host } \\
\text { and the Port Number as 22300. }\end{array}$ & $\begin{array}{l}0.12 . \\
3 / 31 / 99\end{array}$ \\
\hline
\end{tabular}

\subsubsection{SR 757 - Enraf" does not handle "FFFFFF" error message correctly.}

Presently the ENRAF ${ }^{\infty}$ emulator does not support the creation of the "FFFFFF". This feature will not be tested.

\subsubsection{SR 762-U-108 Enraf ${ }^{\text {conversion formula }}$}

\begin{tabular}{|l|l|c|c|}
\hline Step & \multicolumn{1}{|c|}{ Perform } & \multicolumn{1}{c|}{ Verify } & Initial \\
\hline 1. & $\begin{array}{l}\text { Display the conversion } \\
\text { formula for the U-108 } \\
\text { Enraf }\end{array}$ & Verify that the offset value in the formula is 154 & 0.12. \\
\hline
\end{tabular}

\subsubsection{SR 763 - Fix Reference Junction Formulas}

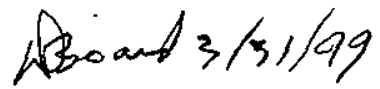

\begin{tabular}{|l|l|c|c|}
\hline Step & \multicolumn{1}{|c|}{ Perform } & \multicolumn{1}{c|}{ Verify } & \multicolumn{1}{c|}{ Initial } \\
\hline 1. & $\begin{array}{l}\text { Run an inspect command that displays } \\
\text { the reference junctions that have a } \\
\text { function definition not equal to } \\
\text { temp_convert. } \\
\text { Temp_convert is set to the following: } \\
\text { Displayed Value }=0.18 * x+32.0 . \\
\text { Where } x \text { is the raw value from the } \\
\text { acromagrm }\end{array}$ & Verify nothing is displayed
\end{tabular}

\subsubsection{SR 769 - Sensor Detail Button on Individual Sensor Trends}

Running the test procedures in the section 6.3.1, "Operation of Sensor Trends" completes this service request. 
HNF-4368, Rev. 0

\subsubsection{SR 770 - Make TMACS Surface Level function definitions uniform}

\begin{tabular}{|l|l|c|c|}
\hline Step & \multicolumn{1}{|c|}{ Perform } & \multicolumn{1}{c|}{ Verify } & Initial \\
\hline 1. & $\begin{array}{l}\text { Run an inspect command } \\
\text { to display the TMACS } \\
\text { Surface Level function } \\
\text { definitions. }\end{array}$ & Verify the definitions are correct and consistent. & $0 . R$. \\
\hline
\end{tabular}

\subsubsection{SR 771 - Add Discrete Update Button to TMACS displays containing Discrete IO points}

\begin{tabular}{|c|c|c|c|}
\hline Step & Perform & Verify & Initial \\
\hline 1. & $\begin{array}{l}\text { Using the inspect } \\
\text { command generate a list of } \\
\text { tanks that have discrete io } \\
\text { points. } \\
\text { [i.e show on a workspace } \\
\text { every kb-workspace W1 } \\
\text { such that there exists a tank } \\
\text { TNK upon W1 and there } \\
\text { exists a subworkspace W2 } \\
\text { of TNK such that (there } \\
\text { exists a discrete-io-point } \\
\text { PT1 upon W2)] } \\
\text { Select a few tanks at } \\
\text { random from this list. }\end{array}$ & Verify that the Discrete Update button is present. & $\begin{array}{c}0.12 \\
3 / 31.199\end{array}$ \\
\hline 2. & $\begin{array}{l}\text { Press the update button. } \\
\text { (Make sure that the } \\
\text { emulator is connected and } \\
\text { communication as the } \\
\text { device being examined.) }\end{array}$ & $\begin{array}{l}\text { Verify the discrete status icons momentarily turn } \\
\text { white (lost communication) then return to the } \\
\text { original status color. } \\
\text { Verify the current alarms screen displays a white } \\
\text { lost communication message followed by a } \\
\text { white established communication message for } \\
\text { the io-station that the discrete io-point is } \\
\text { associated with. }\end{array}$ & $\begin{array}{l}0.12 \\
3 / 3 / / 8 q \\
\operatorname{sea} \\
E x \cos \pi \\
12\end{array}$ \\
\hline
\end{tabular}


HNF-4368, Rev. 0

\subsubsection{SR 772 - Correct TMACS Data History Recovery}

\begin{tabular}{|l|l|c|c|}
\hline Step & \multicolumn{1}{|c|}{ Perform } & \multicolumn{1}{c|}{ Verify } & Initial \\
\hline 1. & $\begin{array}{l}\text { Display the trends for the } \\
\text { same sensors that were } \\
\text { selected from production } \\
\text { system prior to running this } \\
\text { test. (See Prerequisites) }\end{array}$ & Verify the trends are comparable & $3 / 31 / 99$ \\
\hline
\end{tabular}

6.8.20 SR 775 - Fix Abort Problem When Discrete Values Are Outside Instrument Limits

\begin{tabular}{|l|l|l|c|}
\hline Step & \multicolumn{1}{|c|}{ Perform } & \multicolumn{1}{|c|}{ Verify } & \multicolumn{1}{|c|}{ Initial } \\
\hline 1. & $\begin{array}{l}\text { Using the AcromagTM } \\
\text { emulator generate an out of } \\
\text { range value for a discrete } \\
\text { io-point. } \quad\end{array}$ & $\begin{array}{l}\text { Verify the system log does display an abort } \\
\text { message for the procedure named "log-discrete- } \\
\text { io-point-to-disk". See Exceptore } \\
\text { Display the system } \\
\text { logbook. }\end{array}$ & $3 / 3 / 99$ \\
\hline
\end{tabular}

\subsubsection{SR 782 - File Read Status On TMACS Startup}

Running the test procedures in the section 6.1.1 "Startup" completes this service request.

\subsubsection{SR 783 - Correct Scaling problem with Individual Sensor Trends}

\begin{tabular}{|c|c|c|c|}
\hline Step & Perform & Verify & Initial \\
\hline 1. & $\begin{array}{l}\text { Select a sensor at random. } \\
\text { Generate history data for } \\
\text { that sensor that is lower } \\
\text { than the low alarm limit. } \\
\text { (With in } 5 \text { times the alarm } \\
\text { limit span) } \\
\text { Display the individual } \\
\text { sensor trend for the sensor } \\
\text { selected. }\end{array}$ & $\begin{array}{l}\text { Verify that the both the data and the alarm limits } \\
\text { are displayed on the individual trend chart. }\end{array}$ & $\begin{array}{l}0.12 . \\
3 / 31 / 99\end{array}$ \\
\hline
\end{tabular}




\begin{tabular}{|c|c|c|c|}
\hline \multirow{2}{*}{$\frac{\text { Step }}{2 .}$} & Perform & Verify & Initial \\
\hline & $\begin{array}{l}\text { Select a sensor at random. } \\
\text { Generate history data for } \\
\text { that sensor that is greater } \\
\text { than the high alarm limit. } \\
\text { (Within } 5 \text { times the alarm } \\
\text { limit span) } \\
\text { Display the individual } \\
\text { sensor trend for the sensor } \\
\text { selected. }\end{array}$ & $\begin{array}{l}\text { Verify that the both the data and the alarm limits } \\
\text { are displayed on the individual trend chart. }\end{array}$ & $\begin{array}{l}0.12 . \\
3 / 31 / 99\end{array}$ \\
\hline
\end{tabular}

\subsubsection{SR 784 - Modify TMACS continuous point processing to assure at least one reading a day}

\begin{tabular}{|l|l|l|c|}
\hline Step & \multicolumn{1}{|c|}{ Perform } & \multicolumn{1}{c|}{ Verify } & \multicolumn{1}{c|}{ Initial } \\
\hline 1. & $\begin{array}{l}\text { Have Test Director start the } \\
\text { continuous sensor emulator } \\
\text { (i.e. AcromagTM emulator). } \\
\text { (Note: AcromagTM } \\
\text { emulator does not support } \\
\text { code-operated-switch) }\end{array}$ & $\begin{array}{l}\text { Verify that the current continuous sensor history } \\
\text { file contains at least one reading for each of the } \\
\text { sensors emulated by the connected emulator. }\end{array}$ & $0 \cdot 2$. \\
$\begin{array}{l}\text { Let the system run over } \\
\text { night. (Note: Test Director } \\
\text { may opt to change the } \\
\text { system clock to simulate } \\
\text { overnight.) }\end{array}$ & & $3 / 99$ \\
\hline
\end{tabular}

\subsubsection{SR 791 - Label Trend Charts that include 2 risers}

\begin{tabular}{|l|l|l|l|}
\hline Step & \multicolumn{1}{|c|}{ Perform } & \multicolumn{1}{|c|}{ Verify } & Initial \\
\hline 1. & $\begin{array}{l}\text { Inspection of the system has } \\
\text { determined that only two tanks did not } \\
\text { have the riser labels. The tanks are as } \\
\text { follows: }\end{array}$ & $\begin{array}{l}\text { Verify the riser labels are present } \\
\text { and correct. }\end{array}$ & $\begin{array}{l}0.12 . \\
\text { BY110 } \\
\text { C106 } \\
\begin{array}{l}\text { Display the user selectable (multiple) } \\
\text { trend charts for the listed tanks. }\end{array}\end{array}$ \\
\hline
\end{tabular}




\subsubsection{SR 823 - Modify User Trend charts to support persistence.}

\begin{tabular}{|c|c|c|c|}
\hline Step & Perform & Verify & Initial \\
\hline 1. & $\begin{array}{l}\text { Click any enabled Tank Icon in the } \\
\text { Hanford Tank Farm Facilities. (The icon } \\
\text { will not be gray.) } \\
\text { Click on a USER SELECTABLE } \\
\text { TRENDS button. (located at the bottom of } \\
\text { the Tank Status workspace.) }\end{array}$ & $\begin{array}{l}\text { Verify that the USER SELECTABLE } \\
\text { TRENDS workspace appears. }\end{array}$ & $\begin{array}{l}0 . R \\
3 / 31 / 99\end{array}$ \\
\hline 2. & $\begin{array}{l}\text { Click any "SELECT TIME } \\
\text { INTERVAL" option. }\end{array}$ & $\begin{array}{l}\text { Note the time interval here } \\
7 \text { DAyS } \\
\text { Verify the following: } \\
\text { A black dot appears in the circle } \\
\text { of the time interval selected. } \\
\text { The Sensor Reading Description } \\
\text { is modified according to the } \\
\text { SELECT TIME INTERVAL } \\
\text { chosen. (Note: Trend graph is } \\
\text { not updated automatically) }\end{array}$ & $\begin{array}{l}0 . R \\
3 / 31 / 99\end{array}$ \\
\hline 3. & Click on the UPDATE GRAPH button & $\begin{array}{l}\text { Verify the Graph/Chart is updated } \\
\text { and has the following: } \\
\text { - The current value for each } \\
\text { sensor on the trend graph } \\
\text { approximates the current value } \\
\text { on the digital display. } \\
\text { - The values line matches the } \\
\text { symbol for each sensor. } \\
\text { - Trend graph label (below the x- } \\
\text { axis of the graph) reads: } \\
\text { "TANK xx-yyy SELECTED } \\
\text { SENSORS INDICATED BY X" } \\
\text { Where "xx-yyy" represents the } \\
\text { name of the tank. } \\
\text { The time scale of the horizontal time } \\
\text { axis is based on the SELECT TIME } \\
\text { INTERVAL chosen. }\end{array}$ & $\begin{array}{l}0 . R \\
3 / 31 / 99\end{array}$ \\
\hline$\frac{4 .}{5 .}$ & $\begin{array}{l}\text { Click on the HIDE WINDOW. } \\
\text { Redisplay the same USER SELECTABLE } \\
\text { TREND. }\end{array}$ & $\begin{array}{l}\text { Verify that the workspace is hidden. } \\
\text { Vcrify the USER SELECTABLE } \\
\text { TRENDS workspace is displayed and }\end{array}$ & $3 / 31 / 99$ \\
\hline
\end{tabular}


HNF-4368, Rev. 0

\begin{tabular}{|c|c|c|c|}
\hline Step & Perform & Verify & \\
\hline & & $\begin{array}{l}\text { the following: } \\
\text { A black dot appears in the circle } \\
\text { of the time interval selected as } \\
\text { noted previously. } \\
\text { - The Sensor Reading Description } \\
\text { is according to the SELECT } \\
\text { TIME INTERVAL. } \\
\text { The current value for each } \\
\text { sensor on the trend graph } \\
\text { approximates the current value } \\
\text { on the digital display. } \\
\text { The values line matches the } \\
\text { symbol for each sensor. } \\
\text { Trend graph label (below the } x \text { - } \\
\text { axis of the graph) reads: } \\
\text { "TANK xx-yyy SELECTED } \\
\text { SENSORS INDICATED BY X" } \\
\text { Where "xx-yyy" represents the } \\
\text { name of the tank. } \\
\text { The time scale of the horizontal } \\
\text { time axis is based on the } \\
\text { SELECT TIME INTERVAL. }\end{array}$ & $\begin{array}{l}O . R . \\
3 \mid 31 / 99\end{array}$ \\
\hline
\end{tabular}

\subsubsection{SR 828 - Re-Span SY101 ENRAF}

\begin{tabular}{|c|c|c|c|}
\hline Step & Perform & Expected Result & Initial \\
\hline 1. & $\begin{array}{l}\text { Call up the sensor details for } \\
\text { the ENRAF level sensor on } \\
\text { Tank SYI0l. (Sensor details } \\
\text { is accessed through the } \\
\text { button in the upper right } \\
\text { hand corner on the individual } \\
\text { sensor trend workspace.) }\end{array}$ & $\begin{array}{l}\text { Verify the sensor details for the sensor are } \\
\text { displayed and that the Formula Expression is as } \\
\text { follows: } \\
\text { "SurLev-convert-100 }(x)=(0.01 * x) \text { " }\end{array}$ & $\begin{array}{l}O . R \\
3 / 31 / 99\end{array}$ \\
\hline 2. & $\begin{array}{l}\text { Use the Formula } \\
\text { expression and Raw Value } \\
\text { from the sensor details } \\
\text { button on the sensor's } \\
\text { trend to calculate the } \\
\text { current reading for the }\end{array}$ & Write the value here $\frac{40,000}{7,500}$ & $\begin{array}{l}0.12 \\
3 / 31 / 99\end{array}$ \\
\hline
\end{tabular}


HNF-4368, Rev. 0

\begin{tabular}{|c|c|c|c|}
\hline Step & Perform & Expected Result & Initial \\
\hline & sensor. & & \\
\hline 3. & $\begin{array}{l}\text { Compare the Current } \\
\text { Reading with the reading } \\
\text { in Step } 2 \text {. }\end{array}$ & Verify that the readings are the same. & $\begin{array}{l}0 . R \\
3 / 31 / 99\end{array}$ \\
\hline 4. & $\begin{array}{l}\text { Examine the trend chart for } \\
\text { this sensor. }\end{array}$ & $\begin{array}{l}\text { Verify that the value graphed approximates the } \\
\text { value recorded in Step } 2 \text {. (Note: Three or } \\
\text { more points are needed for auto scaling.) }\end{array}$ & $\begin{array}{l}0.12 \\
3 / 31 / 99\end{array}$ \\
\hline
\end{tabular}

\subsection{TMACS SHUTDOWN}

\subsubsection{Telewindows ${ }^{(1)}$ Session}

\begin{tabular}{|c|c|c|c|}
\hline Step & Action & Verify & Initial \\
\hline 1. & $\begin{array}{l}\text { On the TMACS screen, type } \\
\text { Control-Y. }\end{array}$ & $\begin{array}{l}\text { Verify that the user mode selection } \\
\text { workspace appears on the screen. }\end{array}$ & $\begin{array}{l}0.12 \\
3 / 29 / 99\end{array}$ \\
\hline 2. & $\begin{array}{l}\text { Edit the 'G2 } 2^{\alpha 8} \text { user mode' to be } \\
\text { "shutdown" and click on the } \\
\text { END. }\end{array}$ & $\begin{array}{l}\text { Verify that a warning message } \\
\text { appears indicating that this function } \\
\text { is not available. } \\
\text { Verify the ' } G 2^{\infty}{ }^{\infty} \text { user mode' has } \\
\text { reverted back to "t2-user". }\end{array}$ & $\begin{array}{l}\text { O.R. } \\
3 / 29 / 99\end{array}$ \\
\hline
\end{tabular}

\subsubsection{Central Console}

\begin{tabular}{|c|c|c|c|}
\hline Step & Action & Verify & Initial \\
\hline 1. & On the TMACS screen, type Control-Y. & $\begin{array}{l}\text { Verify that the user mode } \\
\text { selection workspace } \\
\text { appears on the screen. }\end{array}$ & $\begin{array}{l}0 . R \\
3 / 29 / 99\end{array}$ \\
\hline 2. & $\begin{array}{l}\text { Edit the 'G } 2^{\alpha} \text { user mode' to be } \\
\text { "shutdown" and click on the END. }\end{array}$ & $\begin{array}{l}\text { Verify that } \mathrm{G} 2^{\circ} \\
\text { terminates. }\end{array}$ & $\begin{array}{l}0 . \pi 2 \\
3 / 29 / 99\end{array}$ \\
\hline
\end{tabular}


HNF-4368, Rev. 0

\begin{tabular}{|c|c|c|c|}
\hline Step & Action & Verify & Initial \\
\hline 3. & $\begin{array}{l}\text { As part of the shutdown process } \\
\text { TMACS creates the following files in } \\
\text { the directory } \\
\text { F:IBackedUplTMACSWatalCurrent: } \\
\text { - Continuous_Shutdown_History_ } \\
\text { YYYY_MMDD.ascii. } \\
\text { Discrete_Shutdown_History } \\
\text { YYYY_MMDD.ascii. } \\
\text { Where: } \\
\text { YYYY - is the year that the file was } \\
\text { created. } \\
\text { MM - is the month that the file was } \\
\text { created. } \\
\text { DD - is the day that the file was created. }\end{array}$ & $\begin{array}{l}\text { Verify that the files were } \\
\text { created and the format } \\
\text { match the description } \\
\text { given in the LMSI } \\
\text { External Letter, } \\
\text { RGG-SDI-99-00I, } \\
\text { TMACS Data File } \\
\text { Formats, Release 11.0. }\end{array}$ & $\begin{array}{l}\text { O.R. } \\
3 / 2 q / 99\end{array}$ \\
\hline
\end{tabular}




\section{HNF-4368, Rev. 0}

\section{EXCEPTION SHEETS}

The following page is an example of the form used to describe exceptions found during the running of this Acceptance Test Procedure. If exceptions are found, copies of this sheet should be completed and included in the Acceptance Test Report. 


\section{Acceptance Test Procedure \\ Exception Record}

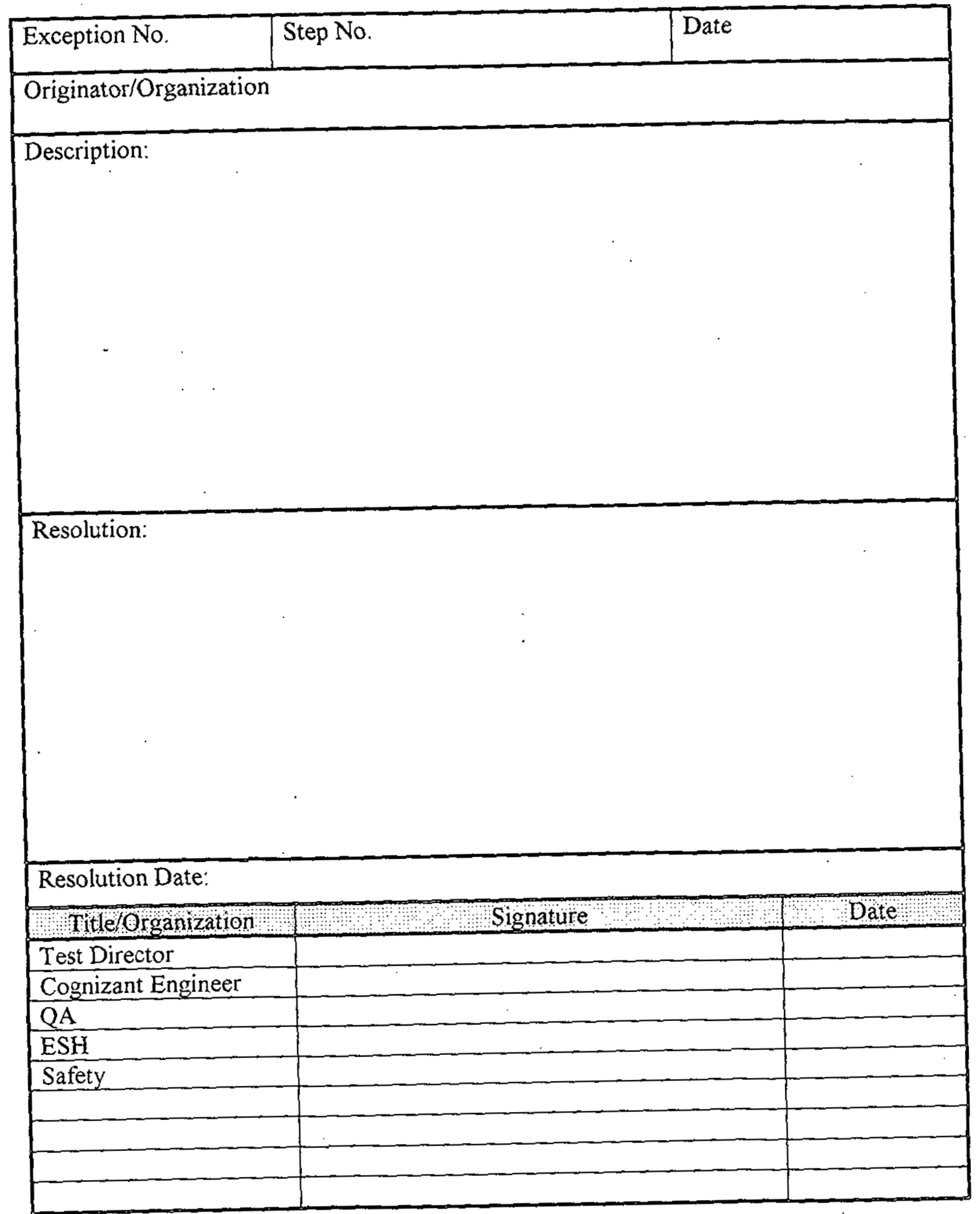


HNF-4368, Rev. 0

\section{PARTICIPATION RECORD SHEET}

The following page is an example of the form used record the participants involved in the running of this Acceptance Test Procedure. This sheet should be completed and included in the Acceptance Test Report. 
HNF-4368, Rev. 0

Acceptance Test Procedure

Participation Record

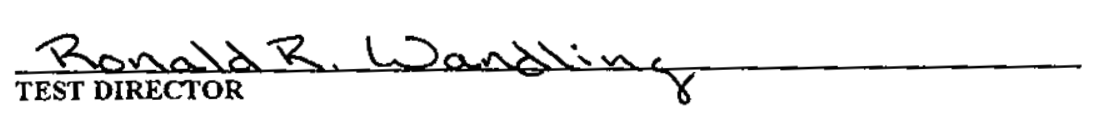

TEST PERFORMANCE GROUP

stem en C cantefle
$3 / 29 / 99 / 3 / 30 / 99 / 3 / 31 / 99$

$3-29-99 / 3-30-99 / 3-31-99$

TEST WITNESS

Don Board 29 ing.

Omar RICEAS

$3-29-99 / 3-30 \cdot 99 / 3 \cdot 31 \cdot 99$
$3-29-96,3-30-99$

63 
HNF-4368, Rev. 0

\section{ACCEPTANCE RECORD SHEET}

The following page is the form used record the participants involved in the running of this Acceptance Test Procedure. This sheet should be completed and included in the Acceptance Test Report. 
HNF-4368, Rev. 0

Acceptance Test Procedure Acceptance Record

CERTIFICATION OF SATISFACTORY EXECUTION

All of the test cases for this test procedure have been tested and all exceptions for this test procedure have been resolved.

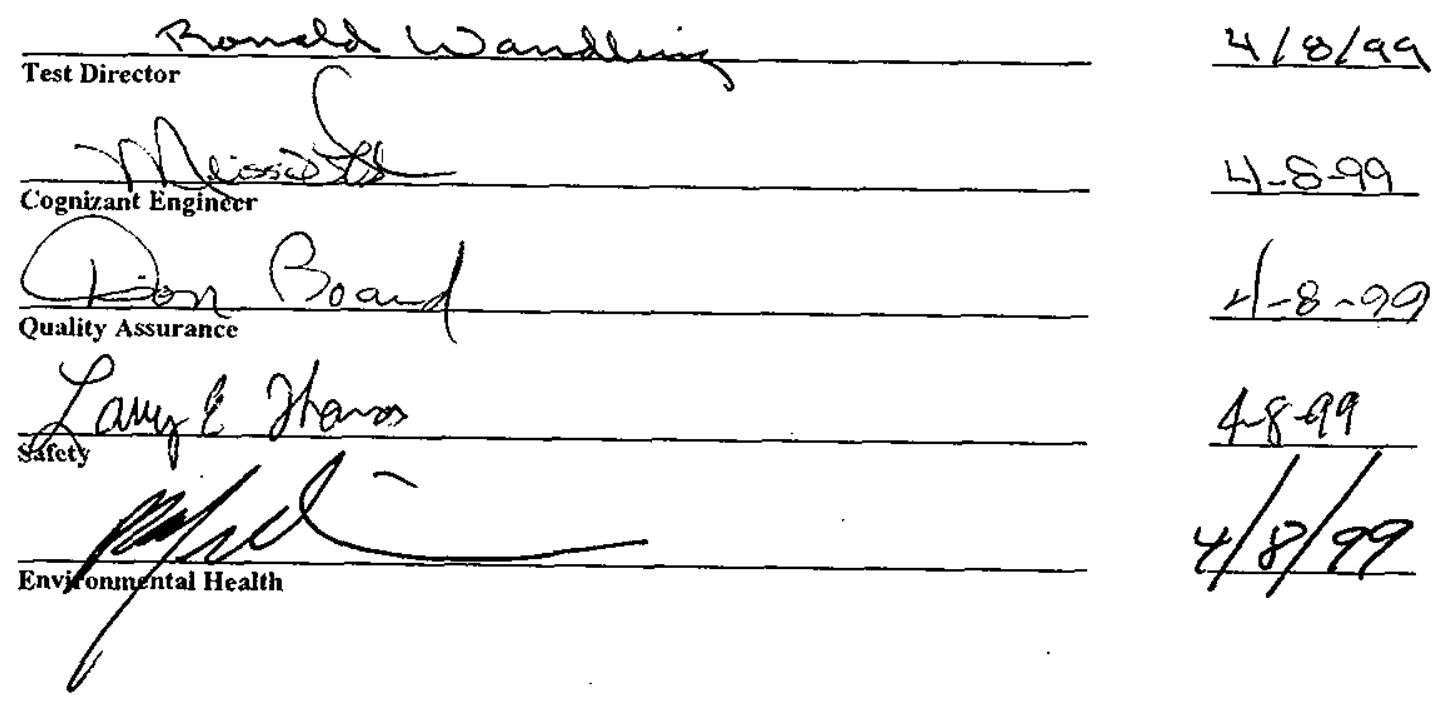

65 
HNF-4368, Rev. 0

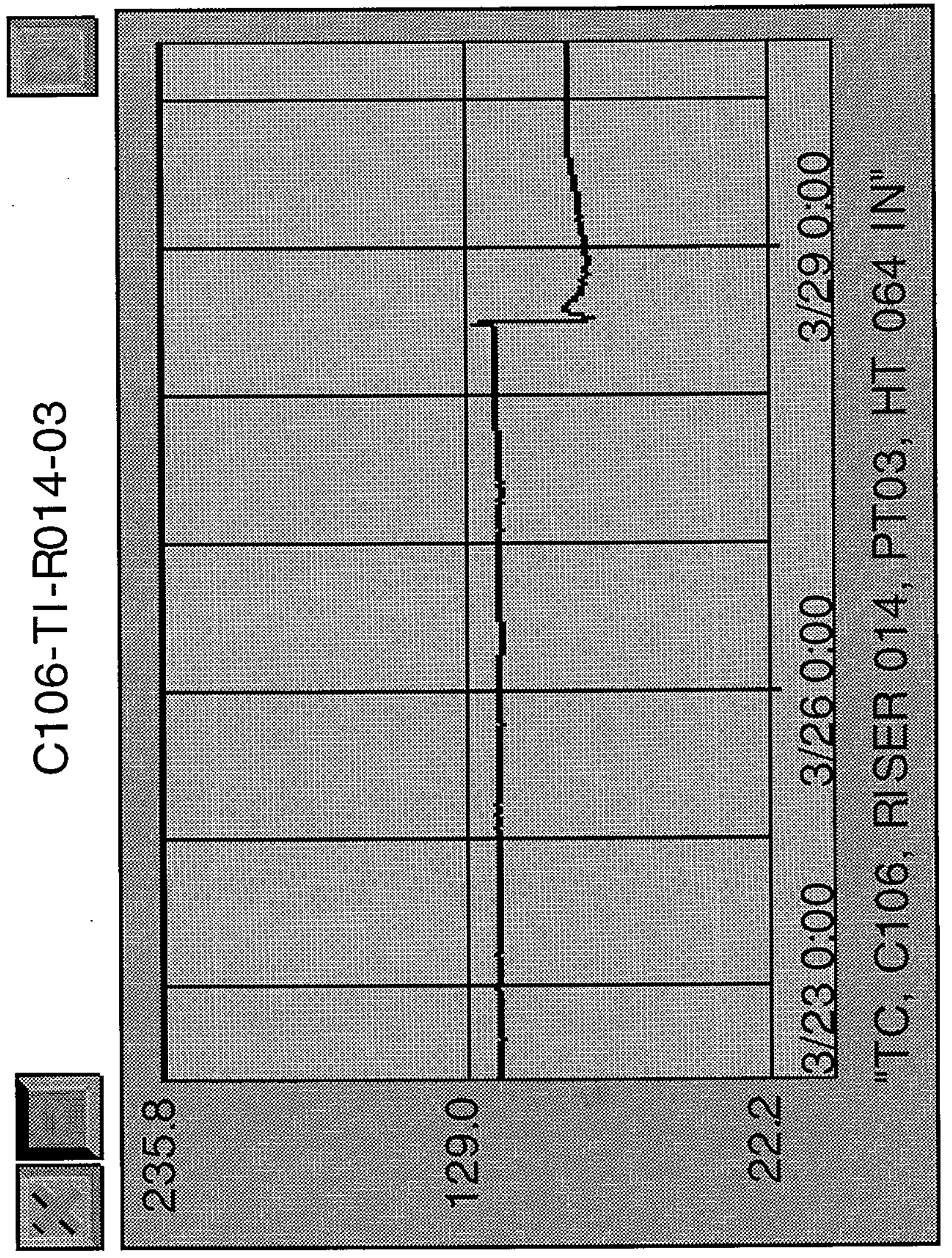


HNF-4368, Rev. 0

\section{Acceptance Test Procedure \\ Exception Record}

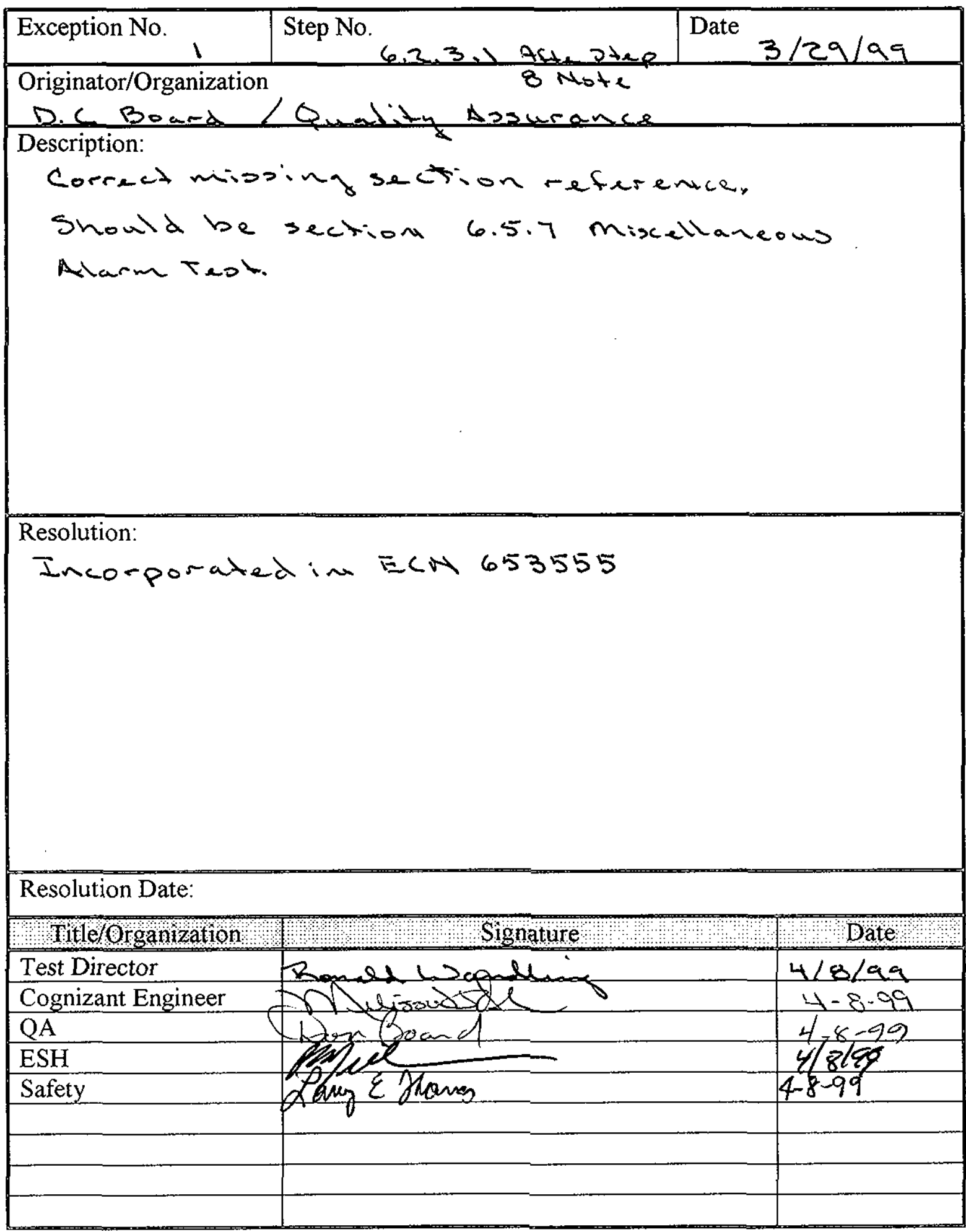


HNF-4368, Rev. 0

Acceptance Test Procedure

Exception Record

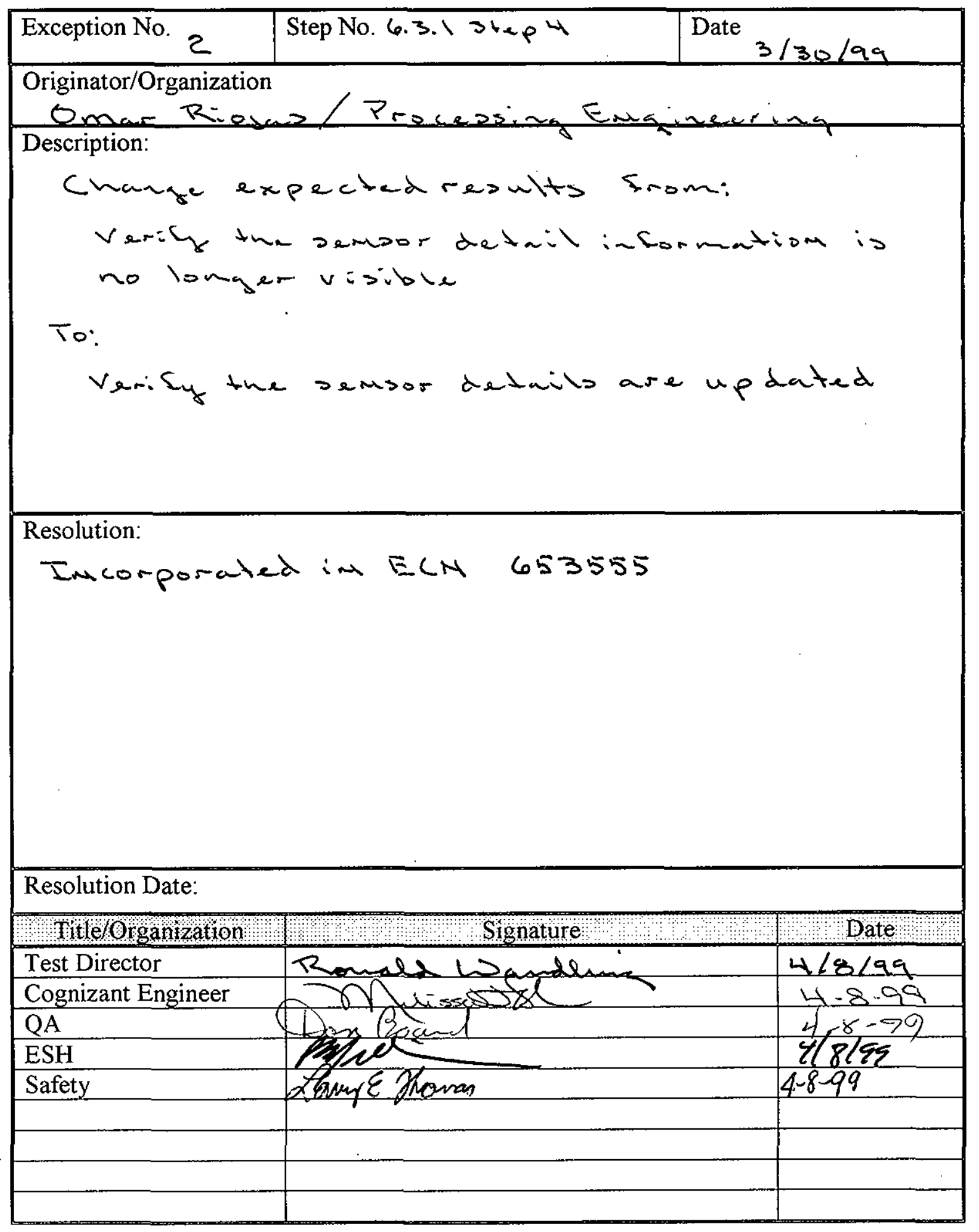

68 
HNF-4368, Rev. 0

\section{Acceptance Test Procedure \\ Exception Record}

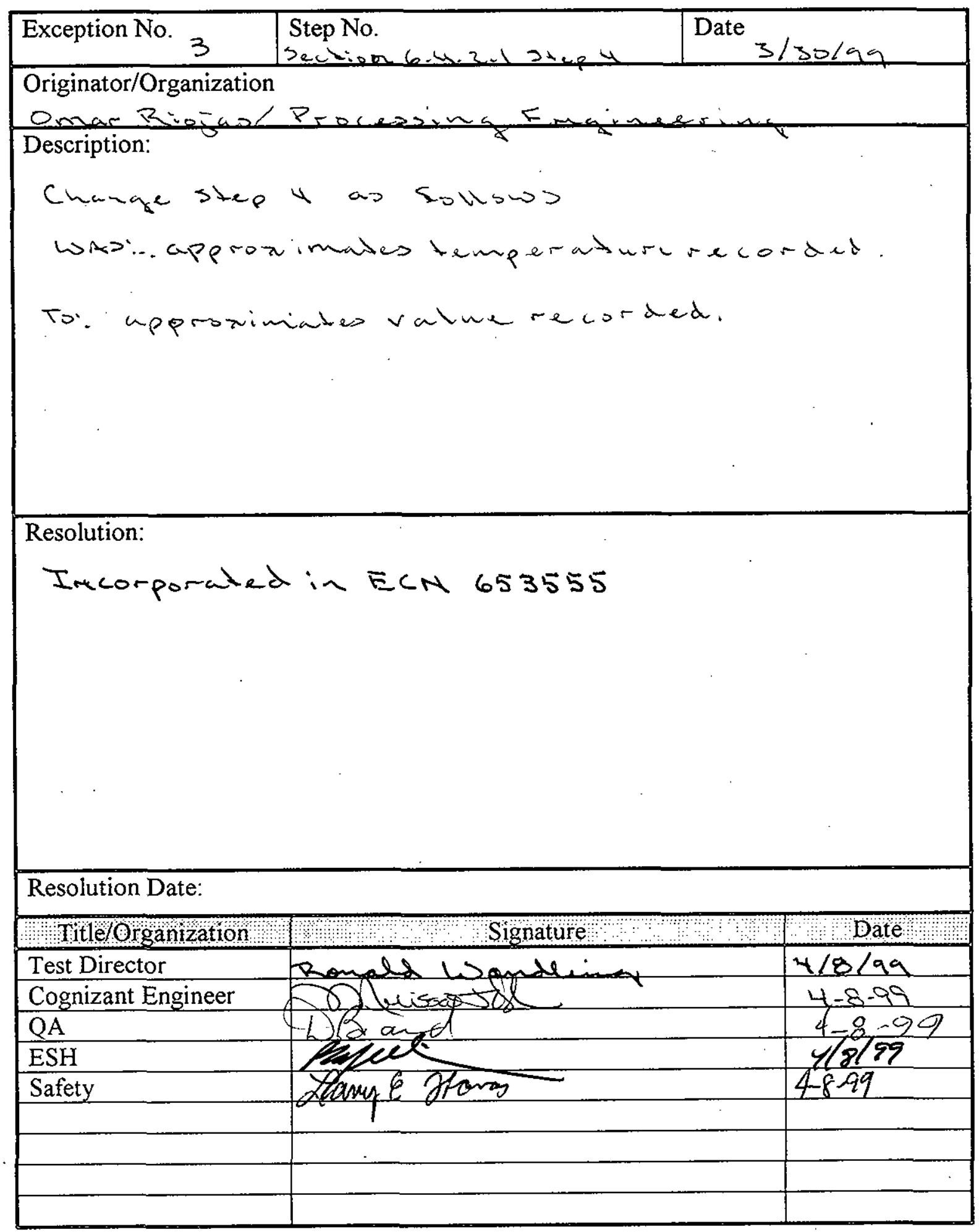


HNF-4368, Rev. 0

\section{Acceptance Test Procedure Exception Record}

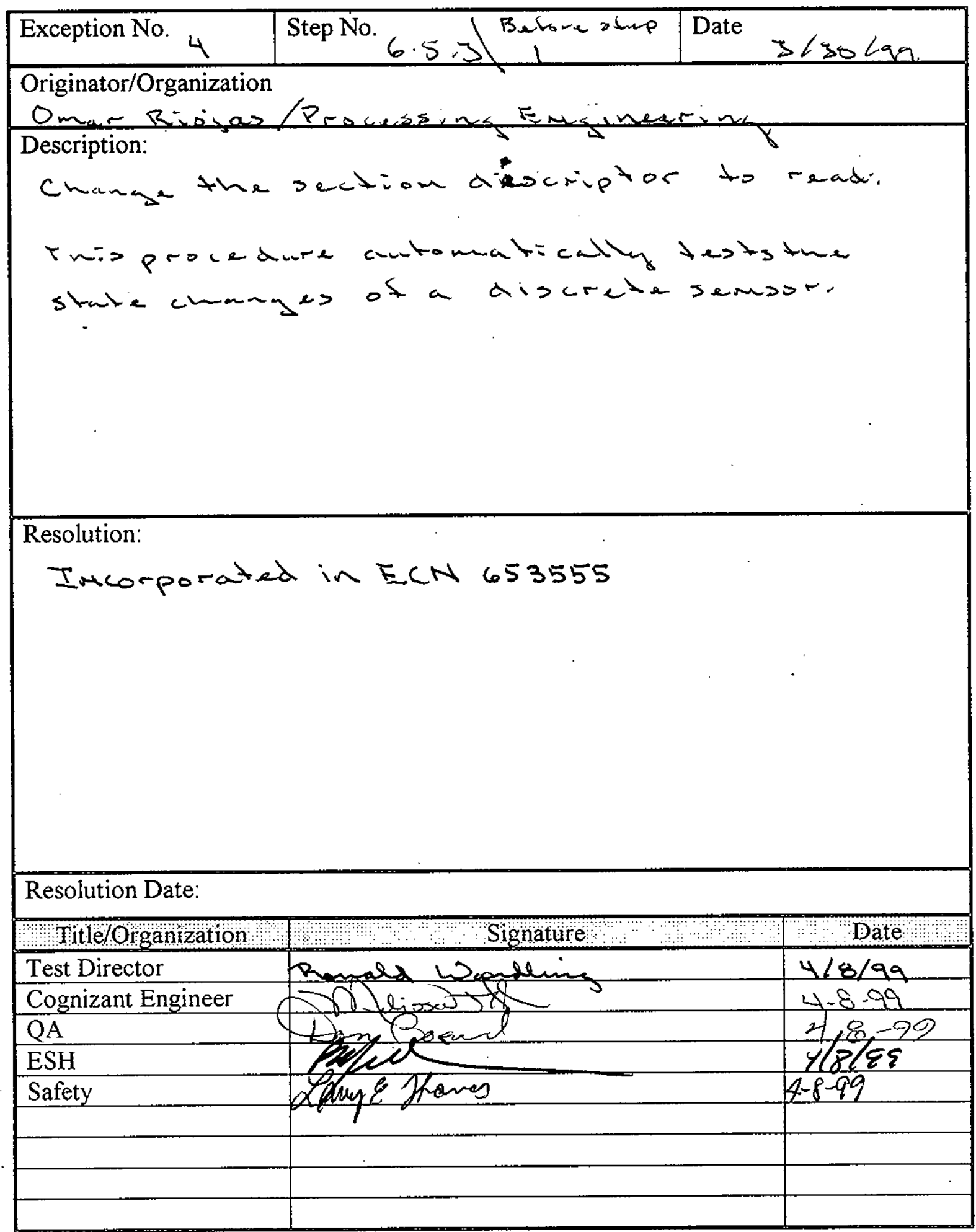




\section{HNF-4368, Rev. 0 \\ Acceptance Test Procedure \\ Exception Record}

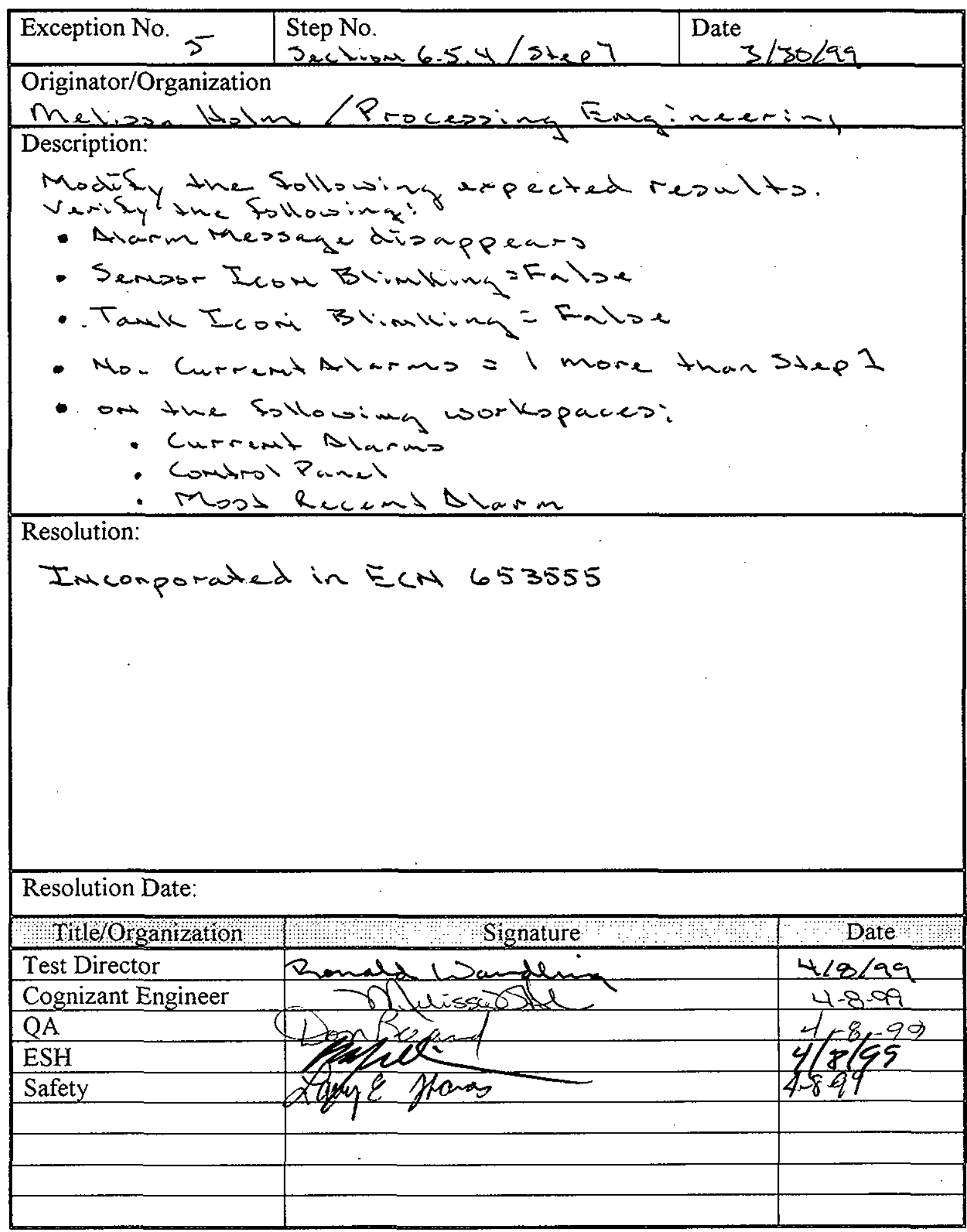




\section{Acceptance Test Procedure Exception Record}

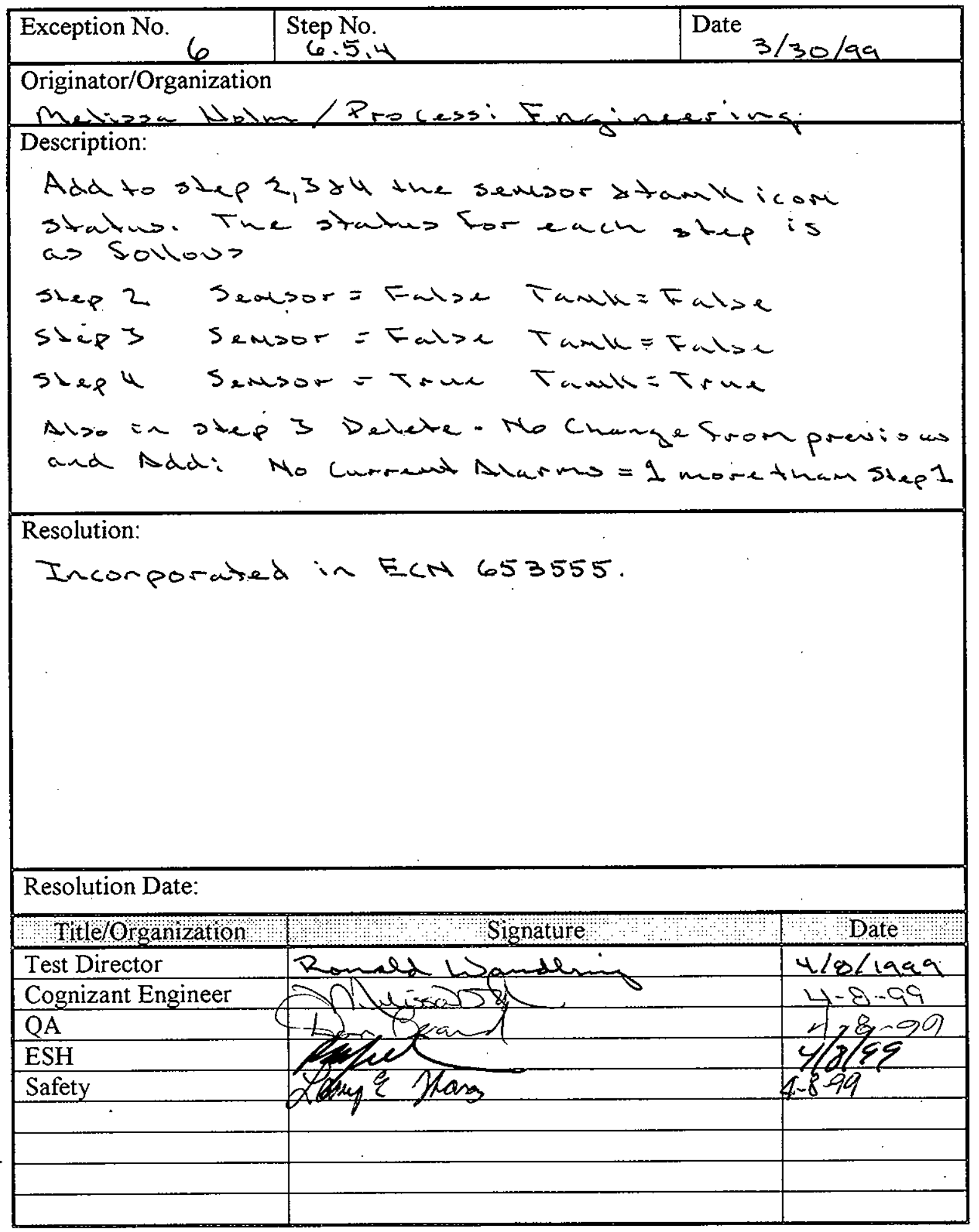




\section{Acceptance Test Procedure Exception Record}

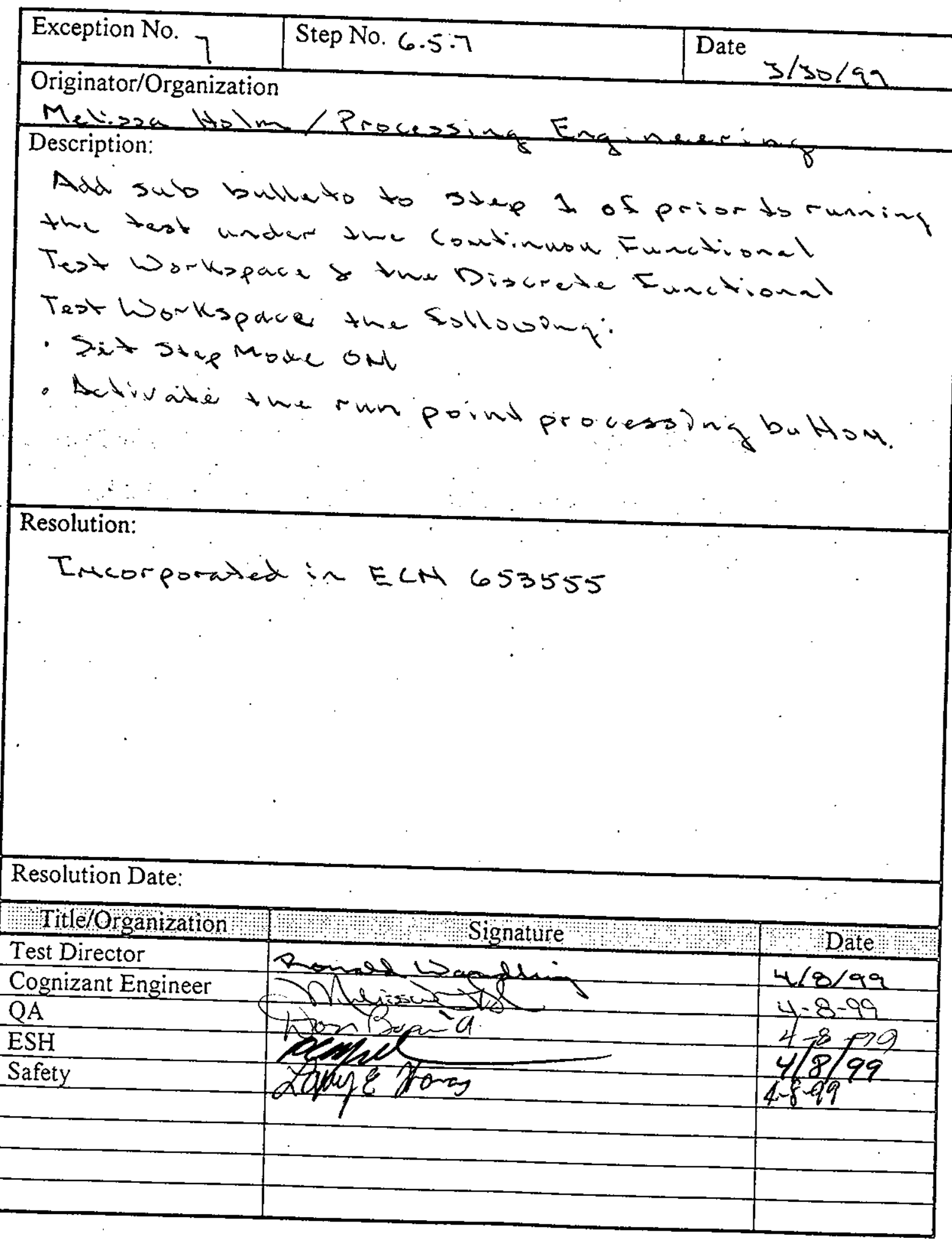


HNF-4368, Rev. 0

\section{Acceptance Test Procedure Exception Record}

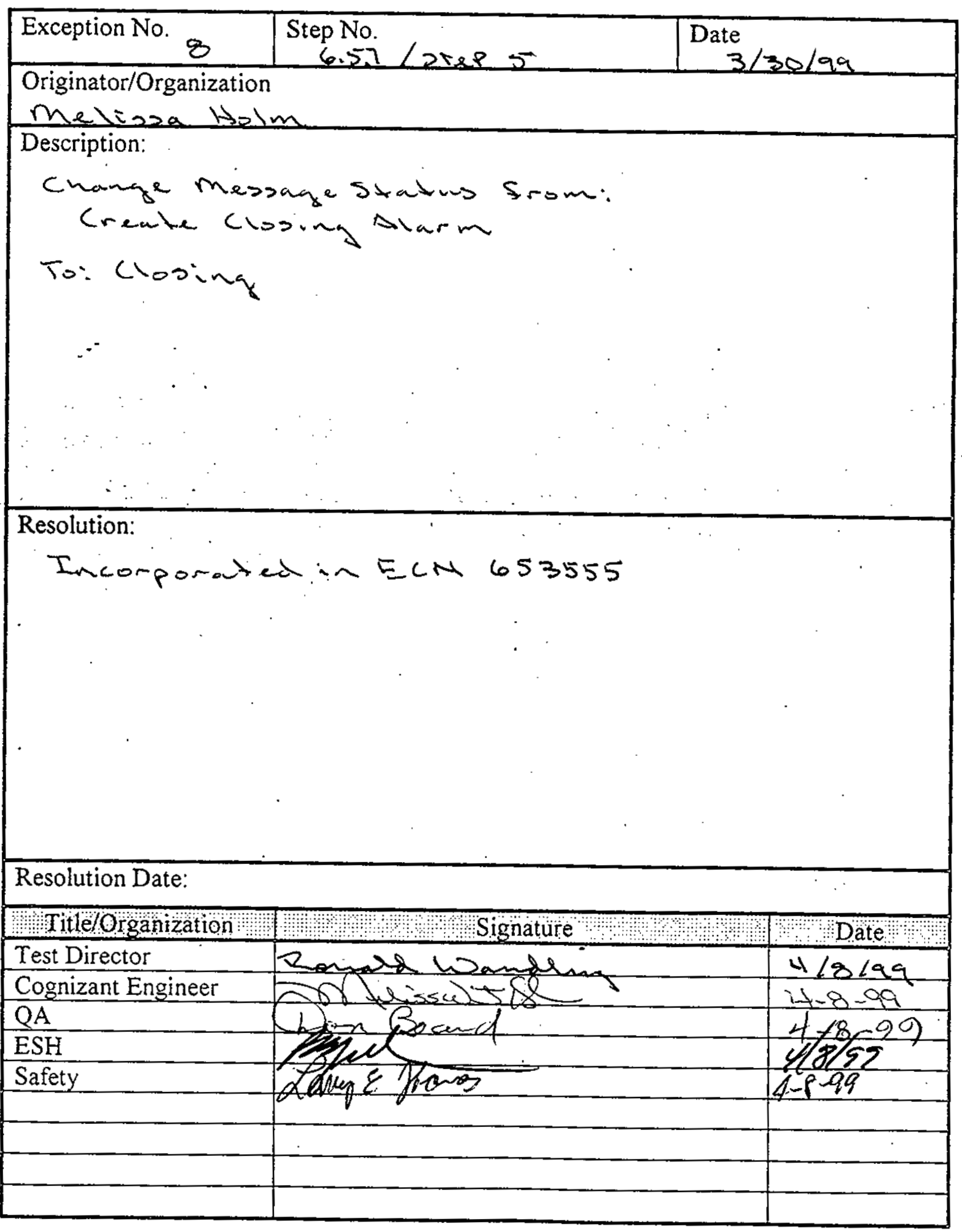


HNF-4368, Rev. 0

\section{Acceptance Test Procedure Exception Record}

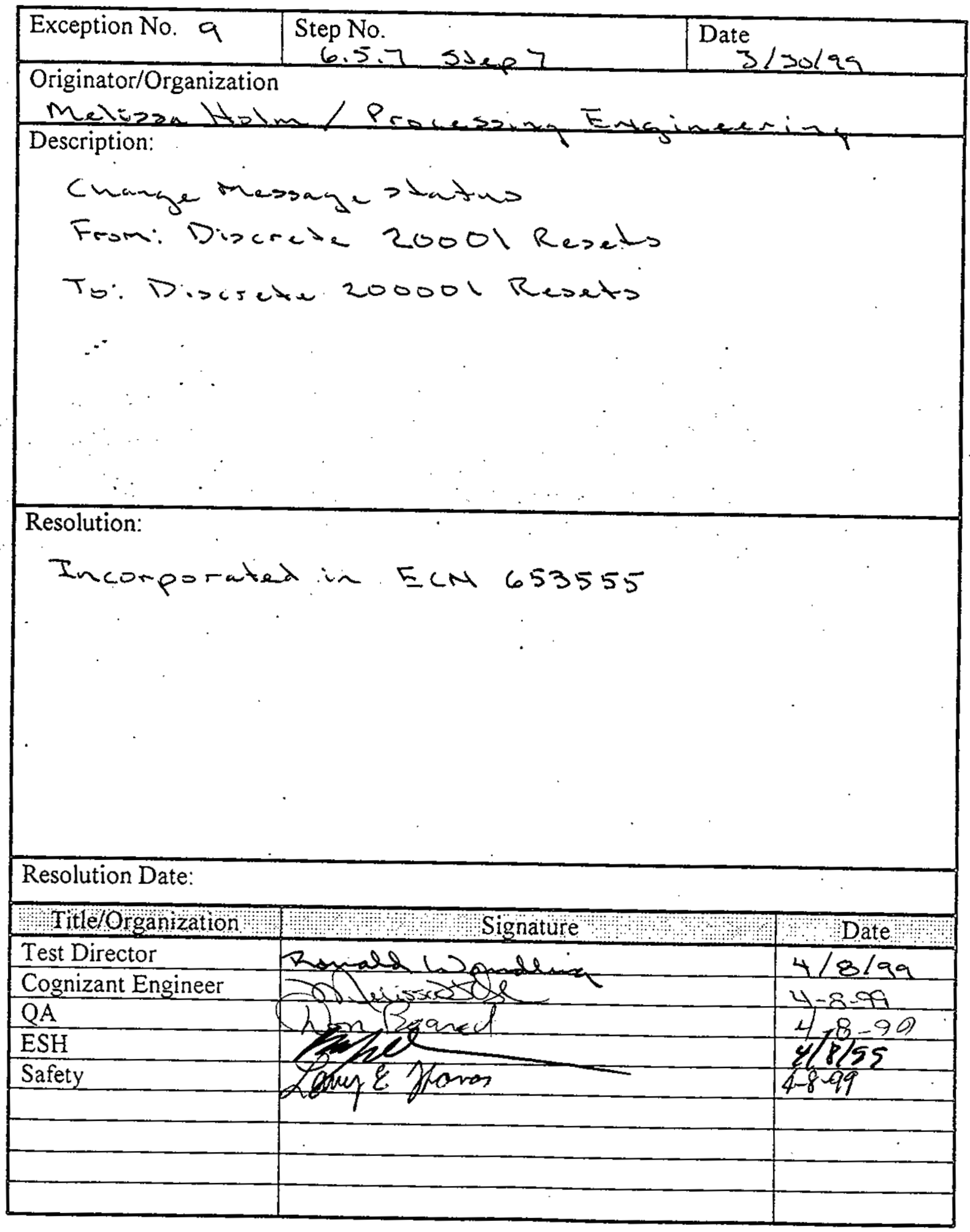


HNF-4368, Rev. 0

\section{Acceptance Test Procedure Exception Record}

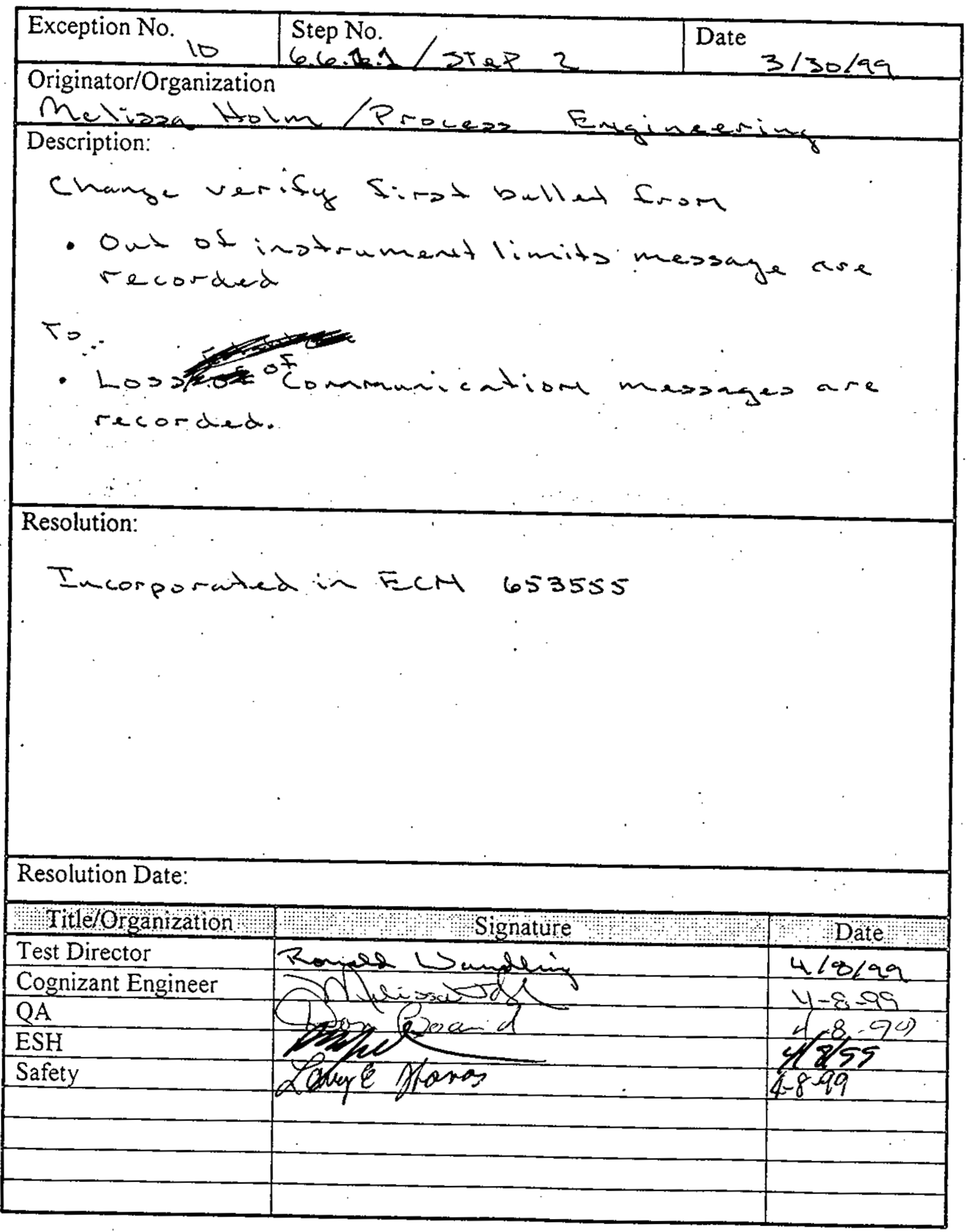


HNF-4368, Rev. 0

\section{Acceptance Test Procedure \\ Exception Record}

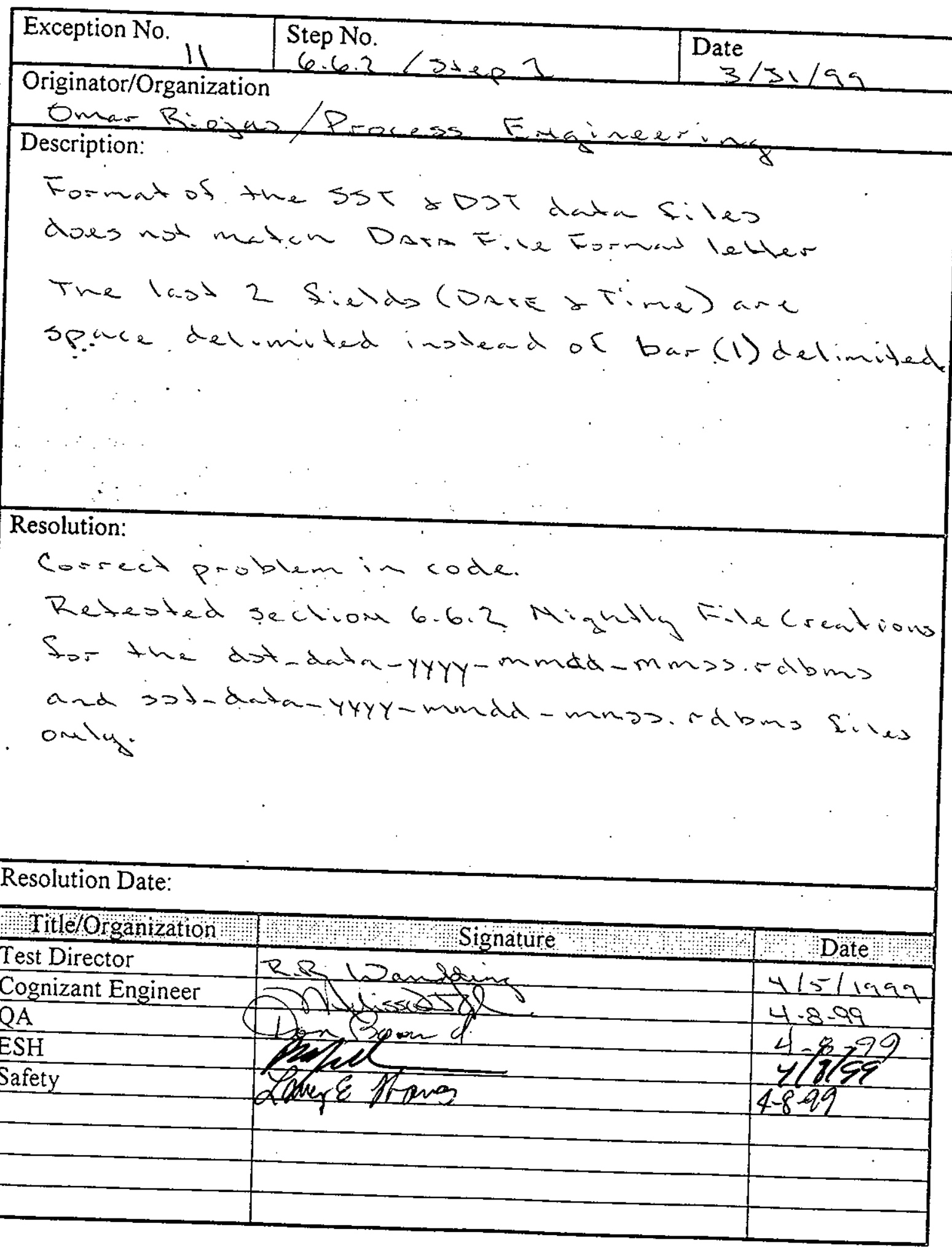


ANF-4368, Rev. 0

\subsubsection{Nightly File Creations}

Eight files are created nightly by TMACS (rdbms files are created around 4:00 AM, all others created around 12:00 AM)

\begin{tabular}{|c|c|c|c|}
\hline Step & Perform & Verify & Initial \\
\hline 1. & $\begin{array}{l}\text { Let the system run over } \\
\text { night. (Note: Test } \\
\text { Director may opt to change } \\
\text { the system clock to } \\
\text { simulate overnight. This } \\
\text { requires time periods } \\
\text { around midnight and } \\
4 A M) \\
\text { Check the location } \\
\text { f: } \backslash \text { BackedUp } \backslash \text { TMACSData } \\
\text { History to determine if the } \\
\text { files have been created. }\end{array}$ & $\begin{array}{l}\text { Verify that the following flat files are created: } \\
\text { - almhst_yyyy_mmdd_mmss.dat } \\
\text { - continuous_sensor_history yyyy_mmdd.ascii } \\
\text { - discrete_sensor_history_yyyy_mmdd.ascii } \\
\text { - equip_fail_yyy__mmdd_mmss.dat } \\
\text { - perf_data_yyyy_mmdd.dat } \\
\text { - test_tank_history_yyyy_mmdd.ascii } \\
\text { - dst_data_yyyy_mmdd_mmss.rdbms } \\
\text { - sst_data_yyyy_mmdd_mmss.rdbms } \\
\text { where: } \\
\text { yyyy = the year } \\
\text { mm = the month } \\
\text { dd = the day } \\
\text { hh = the hour } \\
\text { mm = the minute } \\
\text { Verify that the fields in the files match the } \\
\text { description given in the LMSI External Letter, } \\
\text { RGG-SDI-99-001, TMACS Data File Formats, } \\
\text { Release II.0. }\end{array}$ & \\
\hline
\end{tabular}




\section{Acceptance Test Procedure Exception Record}

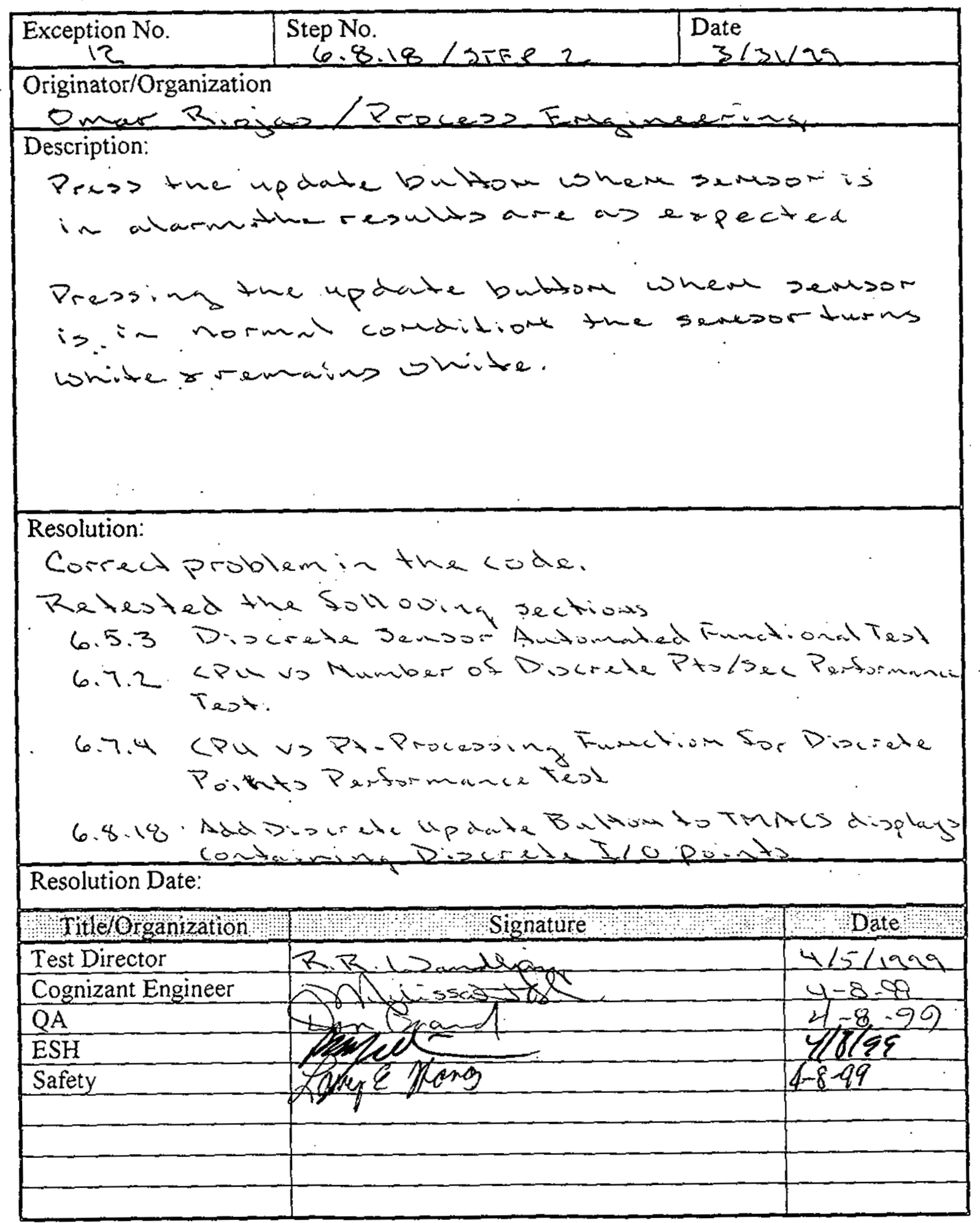




\subsubsection{Discrete Sensor Automated Functional Test}

This procedure automatically tests the state changes of a discrete sensor.

\begin{tabular}{|l|l|l|l|}
\hline Step & \multicolumn{1}{|c|}{ Perform } & \multicolumn{1}{|c|}{ Expected Result } & Initial \\
\hline 1. & $\begin{array}{l}\text { On the POINT } \\
\text { PROCESSING } \\
\text { FUNCTIONAL TEST } \\
\text { workspace click on the } \\
\text { Point Processing for } \\
\text { Discrete Points - All } \\
\text { Functions button }\end{array}$ & $\begin{array}{l}\text { Verify the DISCRETE FUNCTIONAL TEST } \\
\text { workspace appears. }\end{array}$ & \\
\hline 2. & $\begin{array}{l}\text { On the Discrete Functional } \\
\text { Test workspace: } \\
\text { Set the Step Mode to } \\
\text { "Off"” } \\
\text { Set Print Results to "Last" } \\
\text { Activate the " Run Point } \\
\text { Processing “ button. }\end{array}$ & Verify that the process continues to completion. & \\
\hline 3. & Examine the workspace. & Verify no errors are reported. & \\
\hline 4. & Print the final workspace. & Keep printout for project files. & \\
\hline
\end{tabular}


HNF-4368, Rev. 0

4/5/1999 WHC-SD-WM-TRP-105 Rev 11.0 Test Proc 1: Point Processing Page

\section{DISCRETE-PT-PROC-TEST}

\begin{tabular}{|c|c|c|}
\hline Step Number & 10 & Verify \\
\hline Seq-Test Time Stamp & 5 Apr 99 1:34:47 p.m. & \\
\hline Latest Reading & 0 & \\
\hline Last-Good-Reading-At & 5 Арг 99 1:36:55 pm. & \\
\hline Sensor History & 0 & N.A \\
\hline Quality Status & GOOD & NA \\
\hline Alarm State & NORMAL & NA. \\
\hline Annotation & OPEN & NA. \\
\hline Alarm State Changed At & 5 Apr 99 1.36:55 pm. & NA. \\
\hline Icon Blinking $\cdots$ ? & true & NA. \\
\hline Display Color & GPEEN & NA. \\
\hline Blink-Off Color & GRAY & NA. \\
\hline Alarm-Aux Color & TRANSPARENT & NA. \\
\hline Background Color & MEDIUM-AQUAMARINE & NA. \\
\hline Icon Blinking $\cdots$ ? & true & \\
\hline Display Color & GREEN & \\
\hline Blink-Off Color & GRAY & \\
\hline Occurred-At & 5 Apr 99 1:36:35 p.m. & NA. \\
\hline Display Color & WHITE & N.A. \\
\hline Alarm Number & 3 & NA. \\
\hline & ander ansos & 0 \\
\hline
\end{tabular}

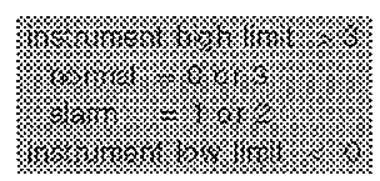

Test-Step

Time-Interval 10

For multi-step test Click Bolow:

1.6.

$$
\begin{array}{|l|l|l|l|l|}
1 & 2 & 3 & 4 & 5 \\
\hline 0 & 3 & 2 & 3 & 4 \\
\hline 6 & 7 & 8 & 9 & 10 \\
\hline 2 & 1 & 4 & -1 & 36 \\
\hline
\end{array}
$$

For single-step test Enter: dip-switch setting 0

Wote: When in the "Step Mode". wait a wininum of the "lest-Step Time-hnteral" betwer steps

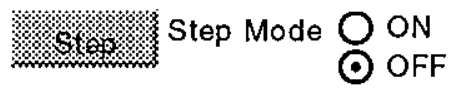

$\begin{array}{ll}\text { Verify Results } & \bigcirc \text { ON } \\ \text { (Min time - 5) } & \odot \text { OFF }\end{array}$

Print Results is (Min time -120)

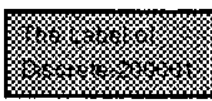

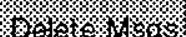




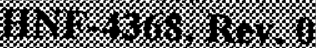
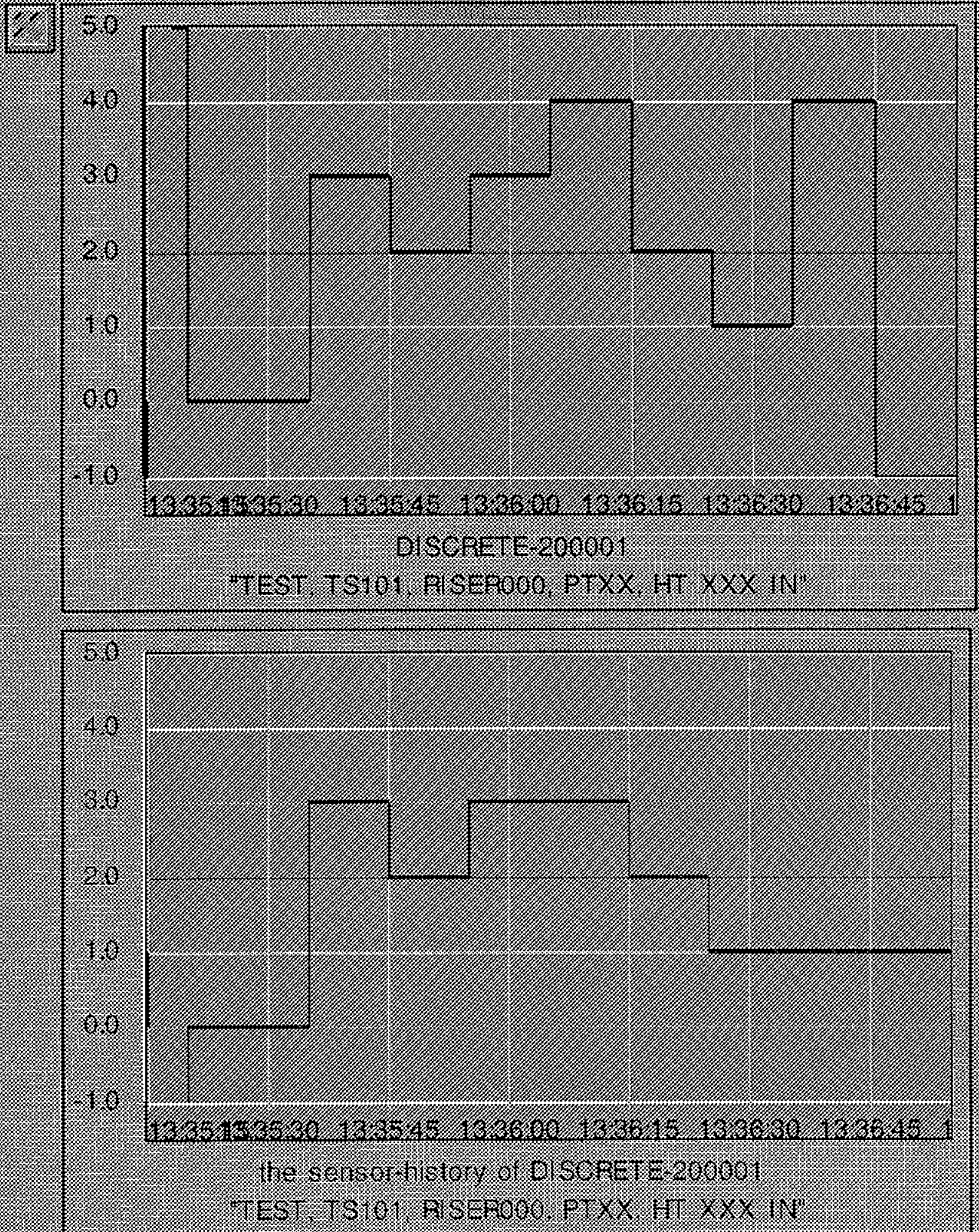
HNF-4368, Rev. 0

\subsubsection{CPU Use Vs Number of Discrete Points/Sec Performance Test}

\begin{tabular}{|l|l|l|l|}
\hline Step & \multicolumn{1}{|c|}{ Perform } & \multicolumn{1}{|c|}{ Expected Result } & Initial \\
\hline 1. & $\begin{array}{l}\text { On the Point Processing } \\
\text { Performance Test workspace click } \\
\text { on the "CPU Use Versus Number } \\
\text { of Discrete Points/Sec" button. }\end{array}$ & $\begin{array}{l}\text { Verify the correct Performance Test } \\
\text { workspace is shown. } \\
\text { Test" button. } \\
\begin{array}{l}\text { After the Test Running box turns } \\
\text { to FALSE examine the results. } \\
\text { (The test will take about } \\
\text { 20 minutes to run) }\end{array}\end{array}$ & $\begin{array}{l}\text { Verify that the test runs and that the } \\
\text { \%CPU/pt/sec values are less than } 0.82 \\
\text { for all values of points/second. }\end{array}$ \\
\hline 3. & $\begin{array}{l}\text { Click on the "Print" button. } \\
\text { Click on the "Start Performance }\end{array}$ & $\begin{array}{l}\text { Verify that the workspace prints. } \\
\text { Attach the printout to this test procedure. }\end{array}$ & \\
\hline 4. & $\begin{array}{l}\text { Hide the Performance Test } \\
\text { workspace(s) }\end{array}$ & Verify the workspace(s) is hidden. & \\
\hline
\end{tabular}




\section{HNF-4368, Rev. 0}

4/5/1999 WHC-SD-WM-TRP-110 Rev 11.0 Test Proc 6: Performance Test Page

\section{CPU Use Versus Number of Discrete PointsiSec}

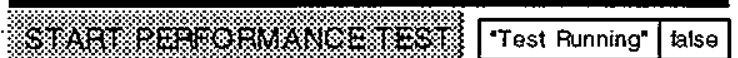
Averaging time (minutes) 1

\begin{tabular}{|c|c|c|c|c|c|}
\hline $\begin{array}{l}\text { No. of } \\
\text { Dscrt. }\end{array}$ & & $\begin{array}{l}\text { Average } \\
\text { (1 Min.) }\end{array}$ & $\begin{array}{l}\text { Minimum } \\
\text { (1 Min.) }\end{array}$ & $\begin{array}{c}\text { Maximum } \\
\text { (1 Min.) }\end{array}$ & $\begin{array}{l}\text { Std Dev } \\
\text { (1 Min.) }\end{array}$ \\
\hline BKGD & BKGD & 0.318 & 0.044 & 0.686 & $60.26 \%$ \\
\hline I/O \& Rule & $\% \mathrm{CPU}$ & 0.174 & 0.007 & 0.595 & $89.23 \%$ \\
\hline 5 & $\% \mathrm{CPU}$ & 1.746 & 1.546 & 2.217 & $9.27 \%$ \\
\hline 10 & $\%$ CPU & 3.328 & 3.145 & 3.962 & $6.66 \%$ \\
\hline 20 & $\% \mathrm{CPU}$ & 6.394 & 6.199 & 6.79 & $2.36 \%$ \\
\hline 30 & $\% \mathrm{CPU}$ & 7.958 & 7.79 & 8.426 & $2.38 \%$ \\
\hline & & & & & \\
\hline 40 & $\% \mathrm{CPU}$ & 11.11 & 11.002 & 11.518 & $1.32 \%$ \\
\hline 50 & $\% \mathrm{CPU}$ & 13.934 & 13.298 & 14.74 & $3.27 \%$ \\
\hline Memory MB & 88.316 & & Pts/sec & $\% \mathrm{cpu} / \mathrm{pt} / \mathrm{sec}$ & \\
\hline Delta & N.A. & & 5 & 0.314 & \\
\hline Pt. Proc. & true & & 10 & 0.315 & \\
\hline Alarm Proc. & true & & 20 & 0.311 & \\
\hline ROC Proc. & N.A & & 30 & 0.259 & \\
\hline Log Proc. & true & & 40 & 0.273 & \\
\hline & & & 50 & 0.275 & \\
\hline Started: & $13: 404 / 5$ & Completed: & $14: 44 / 5$ & Elapsed: & 24 of 18 \\
\hline
\end{tabular}


HNF-4368, Rev. 0

6.7.4 CPU Use Vs Point-Processing Function for Discrete Points Performance Test

\begin{tabular}{|c|c|c|c|}
\hline Step & Perform & Expected Result & Initial \\
\hline 1. & $\begin{array}{l}\text { On the Point Processing } \\
\text { Performance Test } \\
\text { workspace click on the } \\
\text { Click on the "CPU Use } \\
\text { Versus Point-Processing } \\
\text { Function for Discrete } \\
\text { Points" button. }\end{array}$ & $\begin{array}{l}\text { Verify the correct Performance Test workspace is } \\
\text { shown. }\end{array}$ & \\
\hline 2. & $\begin{array}{l}\text { Click on the "Start } \\
\text { Performance Test" button. } \\
\text { After the Test Running } \\
\text { box turns to FALSE } \\
\text { examine the results. (The } \\
\text { test will take about } \\
20 \text { minutes to run) }\end{array}$ & $\begin{array}{l}\text { Verify that the test runs and that for each Point } \\
\text { Processing Breakdown that the following criteria } \\
\text { are met. } \\
\text { for Update Pt. the } \% \text { CPU per points } / \mathrm{sec}<0.28 \\
\text { for Alarm Check the } \% \text { CPU per points } / \mathrm{sec}<0.07 \\
\text { for Log to Disk the } \% \text { CPU per points } / \mathrm{sec}<0.57\end{array}$ & \\
\hline 3. & $\begin{array}{l}\text { Click on the "Print" } \\
\text { button. }\end{array}$ & $\begin{array}{l}\text { Verify that the workspace prints. } \\
\text { Attach the printout to this test procedure. }\end{array}$ & \\
\hline 4. & $\begin{array}{l}\text { Hide the Performance } \\
\text { Test workspace }\end{array}$ & Verify the workspace is hidden. & \\
\hline
\end{tabular}


HNF-4368, Rev. 0

4/5/1999 WHC-SD-WM-TRP-110 Rev 11.0 Test Proc 6: Performance Test Page

CPU Use Versus Point-Processing Function for

Discrete Points

\%
No. of Pts/sec to Process 20

Averaging time (minutes) 1

\begin{tabular}{|c|c|c|c|c|c|}
\hline $\begin{array}{c}\text { Pt. Proc. } \\
\text { Function }\end{array}$ & $\begin{array}{c}\text { Average } \\
(1 \mathrm{Min} .)\end{array}$ & $\begin{array}{c}\text { Minimum } \\
(1 \mathrm{Min} .)\end{array}$ & $\begin{array}{c}\text { Maximum } \\
(1 \mathrm{Min} .)\end{array}$ & $\begin{array}{c}\text { Std Dev } \\
(1 \mathrm{Min} .)\end{array}$ \\
\hline & & & & & \\
\hline All Funcs & $\% \mathrm{CPU}$ & 6.336 & 6.159 & 6.768 & $2.59 \%$ \\
\hline & & & & & \\
\hline w/o Logging & $\% \mathrm{CPU}$ & 3.245 & 3.133 & 3.587 & $4.05 \%$ \\
\hline & & & & & \\
\hline w/o Alarm & $\% \mathrm{CPU}$ & 3.287 & 3.133 & 3.812 & $5.67 \%$ \\
\hline & & & & & \\
\hline w/o Pt Proc & $\% \mathrm{CPU}$ & 1.175 & 0.867 & 1.602 & $19.02 \%$ \\
\hline & & & & & \\
\hline w/o Rule & $\% \mathrm{CPU}$ & 0.076 & 0.004 & 0.308 & $99.49 \%$ \\
\hline & & & & & \\
\hline BKGD & $\% \mathrm{CPU}$ & 0.155 & 0.004 & 0.479 & $98.07 \%$ \\
\hline & & & & & \\
\hline & Memory & 88.778 & 88.778 & 88.778 & $0.00 \%$ \\
\hline & & & & & \\
\hline
\end{tabular}

\begin{tabular}{|c|c|c|c|c|c|}
\hline $\begin{array}{c}\text { Summary } \\
\text { Breakdown }\end{array}$ & $\%$ cpu & & $\begin{array}{c}\text { Pt. Proc. } \\
\text { Breakdown }\end{array}$ & $\%$ cpu/pt/sec & \\
\hline Pt Proc & 5.16 & $81.5 \%$ & Update Pt. & 0.11 & $40.9 \%$ \\
\hline Rule Proc & 1.10 & $17.4 \%$ & Alarm Chk & -0.00 & $-0.8 \%$ \\
\hline 1/O Proc & -0.08 & $-1.3 \%$ & Log to Disk & 0.15 & $59.9 \%$ \\
\hline Bkgd & 0.16 & $2.4 \%$ & & & \\
\hline & & & & & \\
\hline Total: & 6.34 & $100.0 \%$ & Total: & 0.26 & $100.0 \%$ \\
\hline & & & & & \\
\hline Pts/sec: & 20 & \# Cont Pts: & 2141 & \# Dscrt Pts: & 127 \\
\hline & & & & & 19 of 13 \\
\hline Started: & $14: 84 / 5$ & Completed: & $14: 274 / 5$ & Elapsed: & 13 \\
\hline
\end{tabular}


HNF-4368, Rev. 0

\subsubsection{SR 771 - Add Discrete Update Button to TMACS displays containing Discrete I/O points}

\begin{tabular}{|c|c|c|c|}
\hline Step & Perform & Verify & Initial \\
\hline 1. & $\begin{array}{l}\text { Using the inspect } \\
\text { command generate a list of } \\
\text { tanks that have discrete io } \\
\text { points. } \\
\text { [i.e show on a workspace } \\
\text { every kb-workspace W1 } \\
\text { such that there exists a tank } \\
\text { TNK upon W1 and there } \\
\text { exists a subworkspace W2 } \\
\text { of TNK such that ( there } \\
\text { exists a discrete-io-point } \\
\text { PT1 upon W2)] } \\
\text { Select a few tanks at } \\
\text { random from this list. }\end{array}$ & Verify that the Discrete Update button is present. & $\operatorname{mos}$ \\
\hline 2. & $\begin{array}{l}\text { Press the update button. } \\
\text { (Make sure that the } \\
\text { emulator is connected and } \\
\text { communication as the } \\
\text { device being examined.) }\end{array}$ & $\begin{array}{l}\text { Verify the discrete status icons momentarily turn } \\
\text { white (lost communication) then return to the } \\
\text { original status color. } \\
\text { Verify the current alarms screen displays a white } \\
\text { lost communication message followed by a } \\
\text { white established communication message for } \\
\text { the io-station that the discrete io-point is } \\
\text { associated with. }\end{array}$ & \\
\hline
\end{tabular}

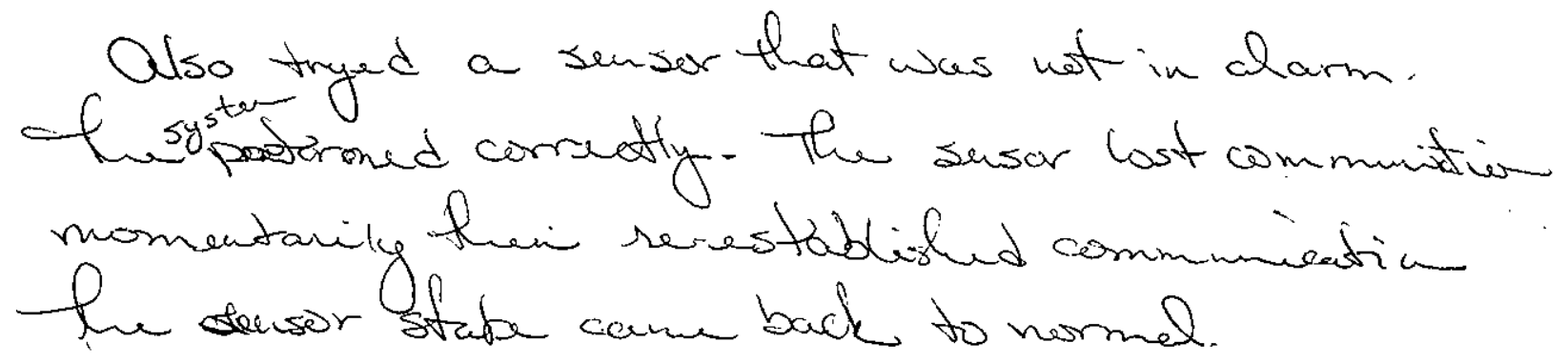

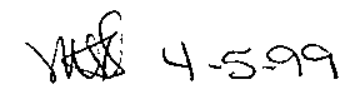


HNF-4368, Rev. 0

\section{Acceptance Test Procedure Exception Record}

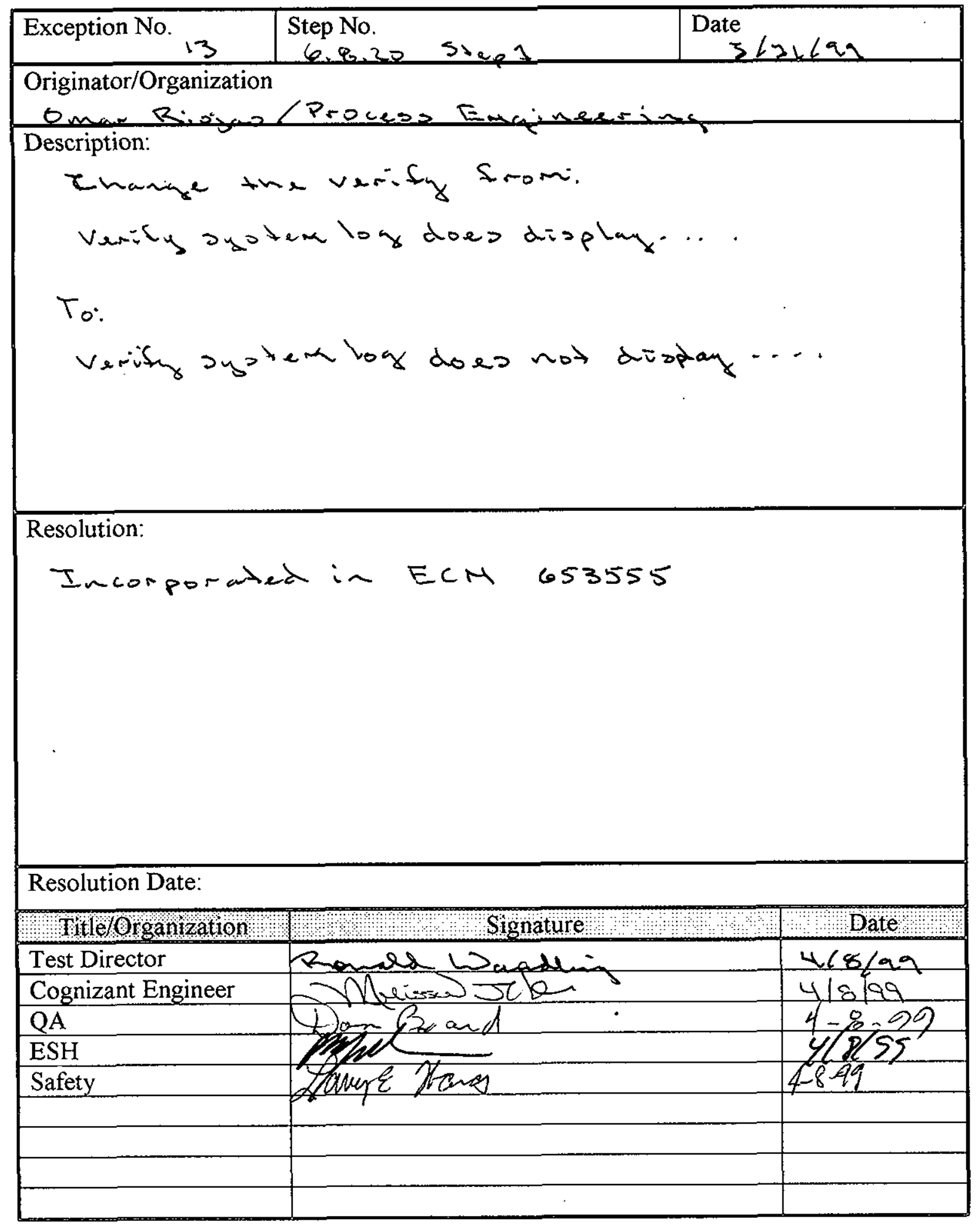




\begin{tabular}{|c|c|c|c|c|c|}
\hline \multicolumn{6}{|c|}{ DISTRIBUTION SHEET } \\
\hline & \multirow{2}{*}{\multicolumn{2}{|c|}{$\begin{array}{l}\text { From } \\
\text { Process Control }\end{array}$}} & & \multicolumn{2}{|c|}{ Page 1 of 1} \\
\hline Distribution & & & & \multicolumn{2}{|c|}{ Date $6 / 10 / 99$} \\
\hline \multicolumn{4}{|l|}{ Project Title/Work Order } & \multicolumn{2}{|c|}{ EDT No. 627426} \\
\hline \multicolumn{4}{|c|}{$\begin{array}{l}\text { Tank Monitor and Control System (TMACS) Revision } 11 \text { Acceptance } \\
\text { Test Review }\end{array}$} & \multicolumn{2}{|c|}{ ECN No. $N / A$} \\
\hline Name & MSIN & $\begin{array}{c}\text { Text } \\
\text { With All } \\
\text { Attach. }\end{array}$ & Text Only & $\begin{array}{l}\text { Attach./ } \\
\text { Appendix } \\
\text { Only }\end{array}$ & $\begin{array}{l}\text { EDT/ECN } \\
\text { Only }\end{array}$ \\
\hline $\begin{array}{l}\text { D. A. Barnes } \\
\text { S. C. Cantre } 1 \\
\text { M. J. Holm } \\
\text { N. W. Kirch } \\
\text { P. C. Miller } \\
\text { D. A. Selle } \\
\text { J. S. Sparks } \\
\text { L. E. Thomas } \\
\text { R. P. Tucker } \\
\text { R. R. Wandling }\end{array}$ & $\begin{array}{l}\text { R2-11 } \\
\text { R3-47 } \\
\text { R2-11 } \\
\text { R2-11 } \\
\text { R1-51 } \\
\text { S5-03 } \\
\text { S7-07 } \\
\text { R3-01 } \\
\text { T4-07 } \\
\text { R1-01 }\end{array}$ & $\begin{array}{l}X \\
X \\
X \\
X \\
X \\
X \\
X \\
X \\
X \\
X\end{array}$ & & & \\
\hline
\end{tabular}

